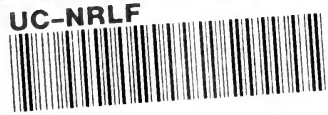

ᄒB 258 08

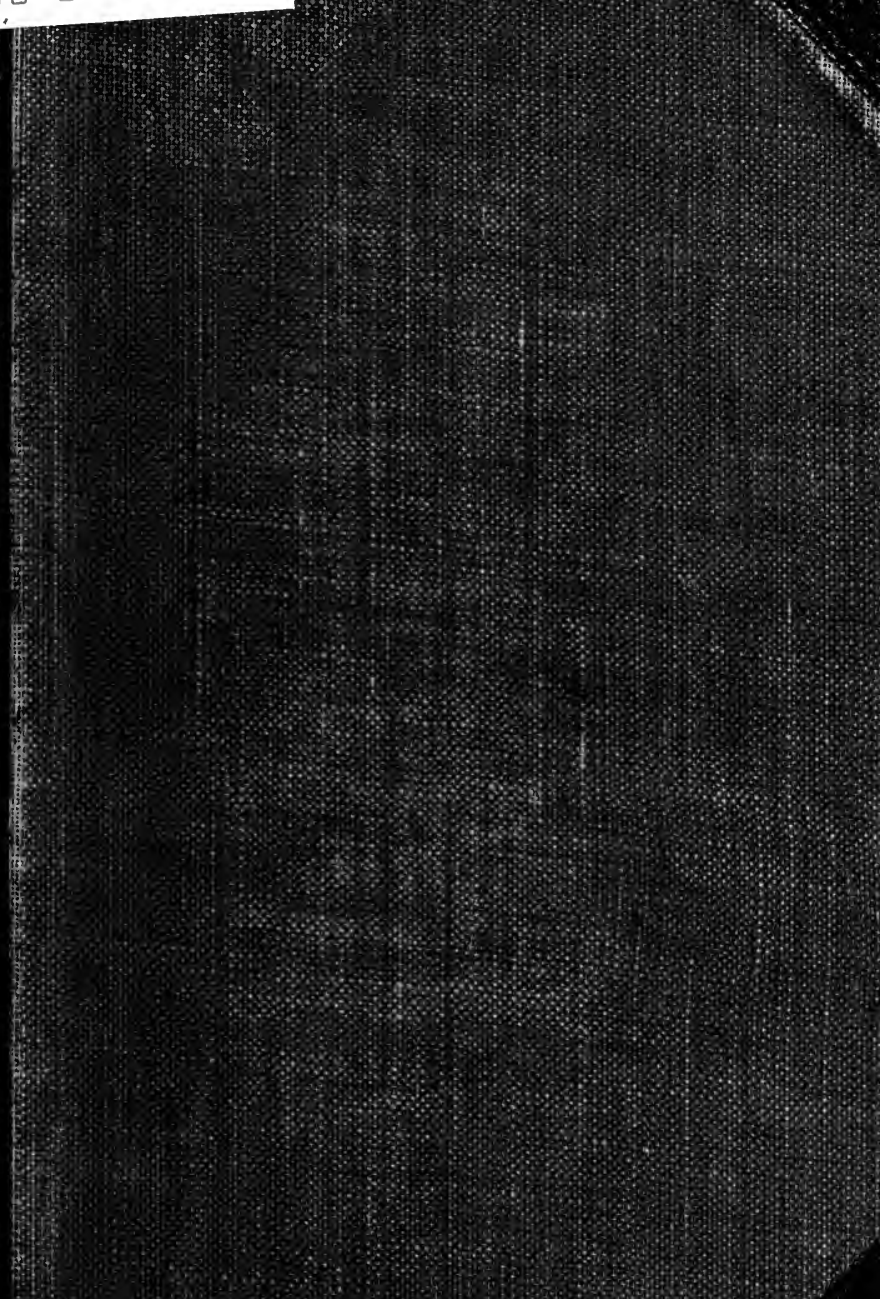




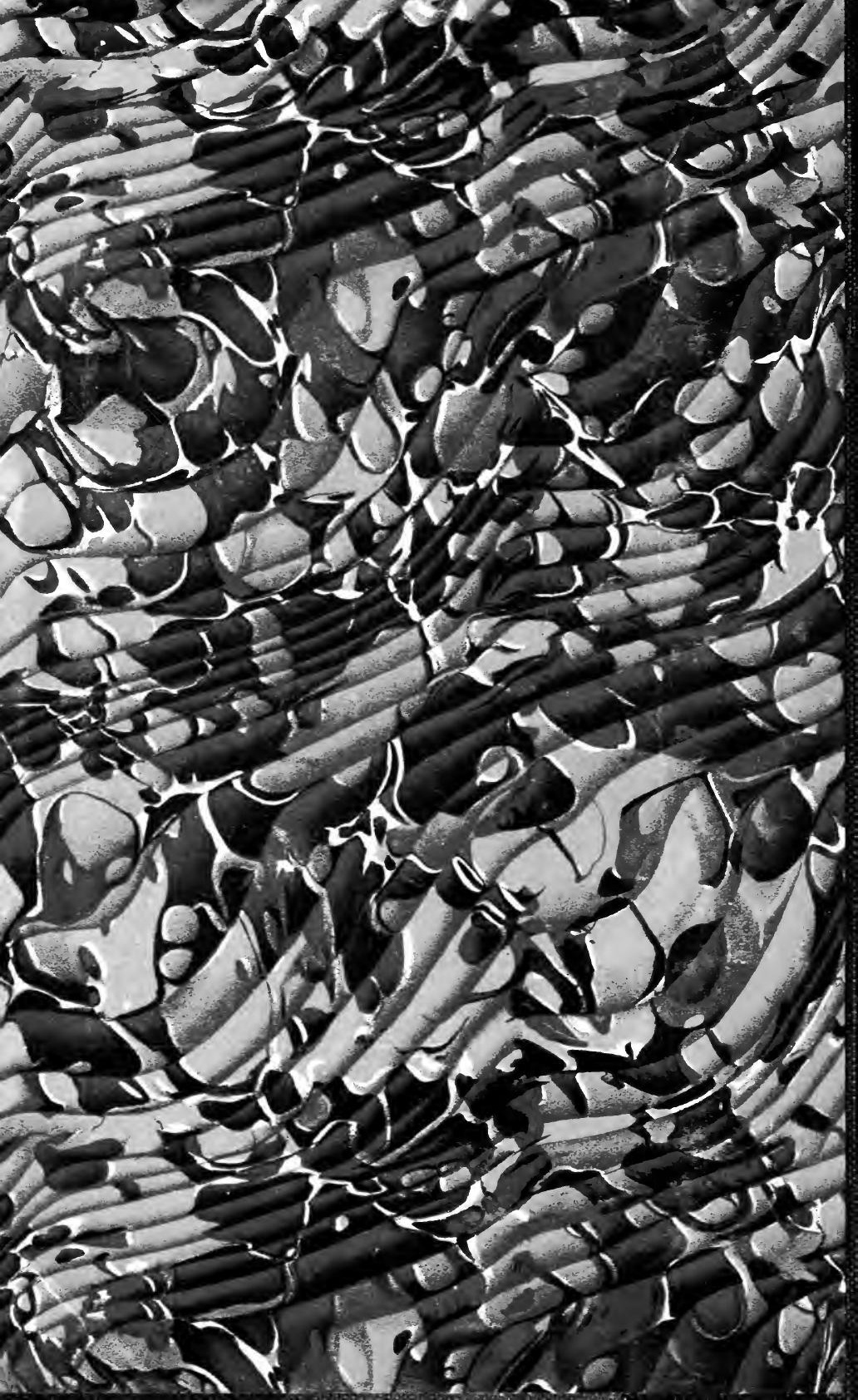


PF

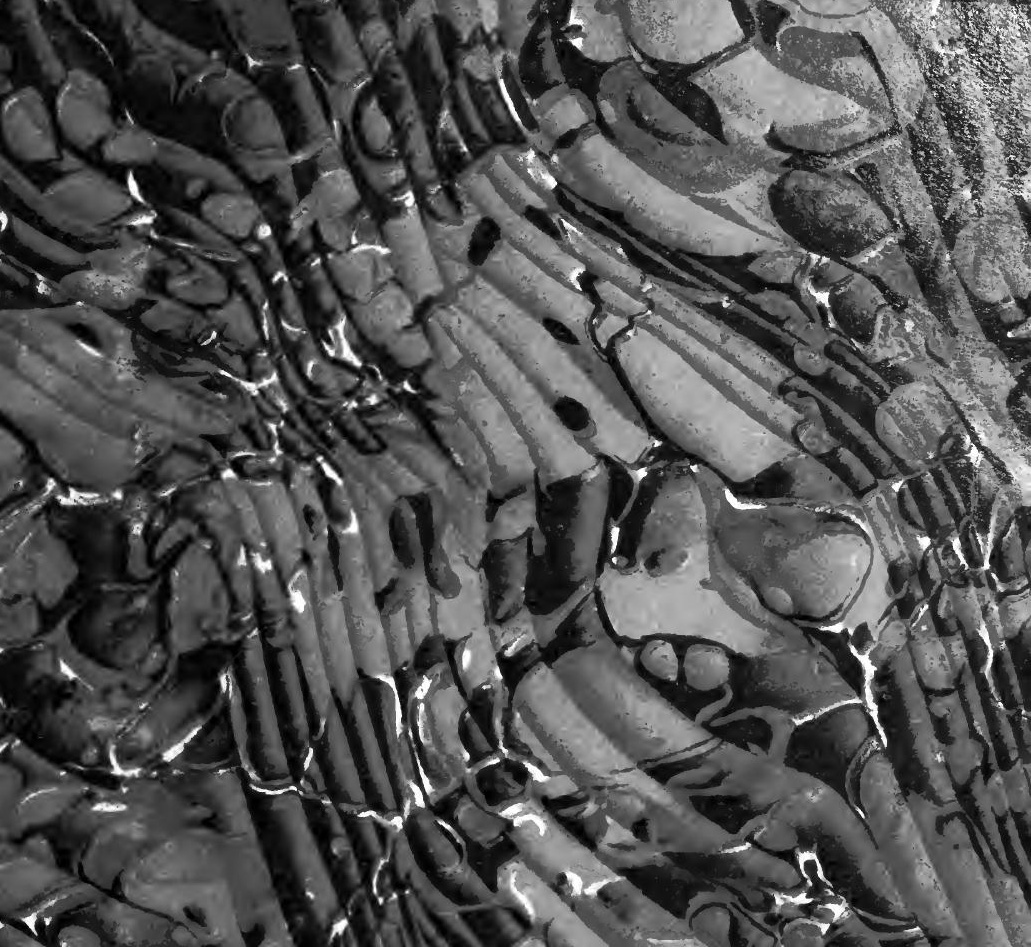

$\lim _{10}$

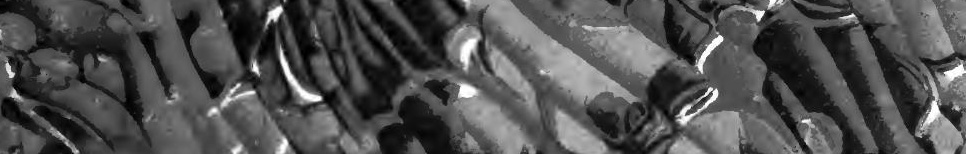

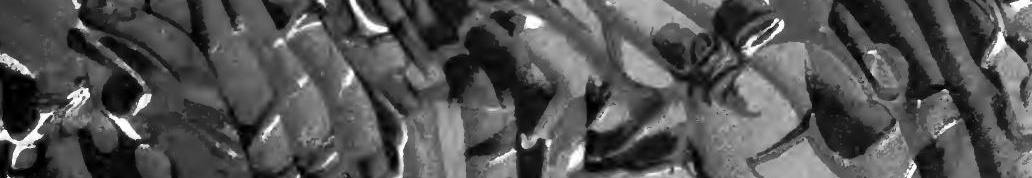
(1) $10,2,1$ dowisora

ino $10\left(2\left(\frac{2)}{2}\right)\right)$ 1.9. 11 .

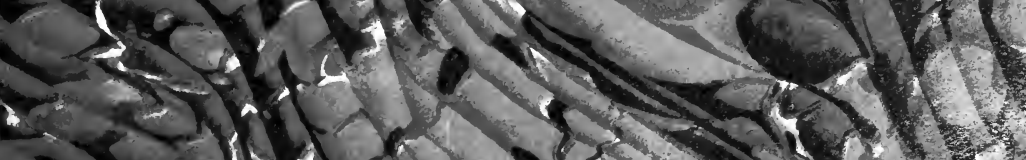

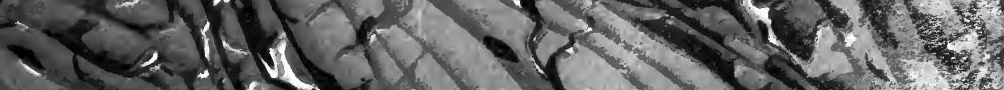
$-10$.

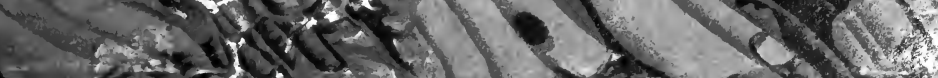

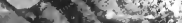







Digitized by the Internet Archive in 2007 with funding from Microsoft Corporation 



\title{
HOW TO ATTRACT AND HOLD AN AUDIENCE
}

\author{
A POPULAR TREATISE ON \\ THE NATURE, PREPARATION, AND DELIVERY \\ OF PUBLIC DISCOURSE
}

BY

J. BERG ESENWEIN, A.M., LrT.D.

PROFESSOR OF THE ENGLISH LANGUAGE AND LITERATURE IN THE PENNSYlvania militaRy COLlege

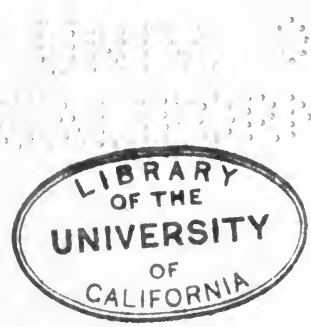

HINDS \& NOBLE, Publishers 4-5-6-1 2-1 3-14 CoOper Institute New York City 


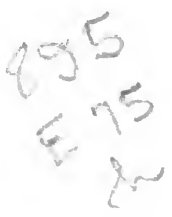

Copyright, rgo2,

BY J. BERG ESENWEIN.

\section{GENERAL}

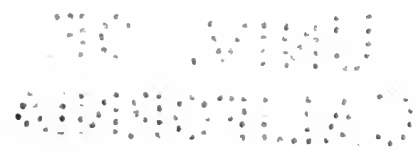




\section{TO MY STUDENTS}

WHO MORE THAN ALL OTHERS HAVE BEEN MY INSTRUCTORS

THIS VOLUME IS AFFECTIONATELY INSCRIBED 
: 


\section{TABLE OF CONTENTS}

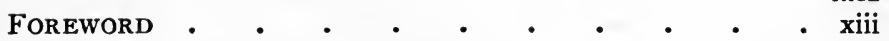

\section{PART I-THE THEORY OF SPOKEN DISCOURSE}

CHAPter I - The Nature of Public Speech

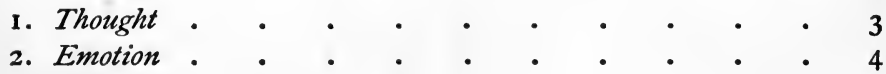

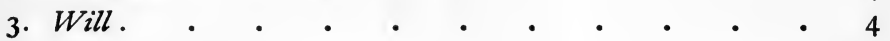

CHAPTER II - THE ForMS OF DISCOURSE

I. Description

(a) Viewpoint

(b) Outline .

(c) Pruning .

(d) Characterization

(e) Order

(f) Summary

2. Narration

(a) Preview.

(b) Subordination of Details . • • • • $\quad$ • 8

(c) Application . $\quad . \quad$. $\quad . \quad$. $\quad . \quad 8$

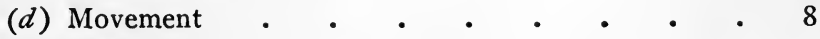

3. Exposition

(a) Definition

(b) Classification

(c) Division .

(d) Generalization . 
4. Argumentation.

PAGE

\section{BUILDING UP AN ARGUMENT}

(a) Getting at Facts

(I) By Intuition . $\quad . \quad \cdot \quad \cdot \quad \cdot \quad$ I $\quad \cdot$ I

(2) By Observation . . . . . . . 12

(3) By Testimony . . . . . . . 12

(4) By Authority . . . . . . . . $\quad$ I2

(b) Drawing Conclusions from Facts - Induction $\quad$ I2

(I) Cause to Effect $\quad . \quad$. $\quad . \quad . \quad$. 12

(2) Effect to Cause . . . . . . . . I3

(3) Circumstantial Evidence . . . . 13

(4) From Experience . . . . . . . 15

(5) From Analogy $\quad . \quad$. $\quad . \quad$. $\quad$. 15

(c) Inferring Facts from General Principles - Deduction . . . . . . . . . 16

(I) The Syllogism $\quad . \quad$. $\quad . \quad . \quad . \quad 16$

(2) The Syllogism contracted . . . . I7

(3) The Syllogism enlarged . . . . . I8

(4) The Syllogism in Series . . . . . I9

(d) Joint Inductive-Deductive Method . . . . $2 \mathrm{I}$

BREAKING DOWN AN ARGUMENT

(a) Simple Rebuttal . . . . . . . $\quad$ • 22

(b) Affirmative Reasoning . . . . . . 22

(c) Elimination of Untenable Grounds . . . $\quad 22$

(I) Reducing to an Absurdity . . . $\quad 22$

(2) Dilemma.$\quad \cdot \quad \cdot \quad \cdot \quad \cdot \quad \cdot 23$

(3) Elimination . . . . . . . 24

(d) Detection of Fallacies . • • • • 25

(I) False Conclusion . $\quad . \quad$ • $\quad$ • 25

(2) Ambiguity . . . . . . . 26

(3) Regging the Question . • . . 27

(4) Reasoning in a Circle . . . . . 27

(5) Imperfect Enumeration . . . . . 28 
5. Persuasion . • . • • • • • 28

(a) Address to the Intellect . . . . . . 29

(b) Appeal to the Emotions . . . . . $\quad 29$

(c) Appeal to the Will . . . . . . 32

6. Summary. • • • • • • • • • 33

CHAPTER III - The Kinds of Public Discourse

I. Impromptu Speeches.' • • • • • • • 34

2. Extemporaneous Addresses . • • • • $\quad$. 35

3. Declamations . • . • • • • • • 35

4. Orations . . . . . . . . . . . 36

CHAPTER IV - THE KINDS OF ORATORY

I. Forensic.

2. Deliberative

3. Sacred .

4. Demonstrative . . . . . . . . . $4 \mathrm{I}$

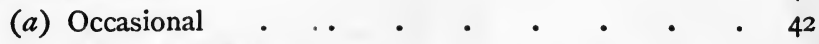

(I) Anniversary ..$\quad \cdot \quad \cdot \quad \cdot \quad \cdot \quad 42$

(2) Dedicatory.$\quad \cdot \quad \cdot \quad \cdot \quad \cdot \quad \cdot 42$

(3) Commemorative . • . . . 42

(b) Eulogy and Invective . • • • • 442

(c) Popular . • • • • • • • • • 43

CHAPtER V-Eloquence • • • • • 44

PART II - PREPARATION OF THE DISCOURSE

\section{CHAPTER VI-ORIGINALITY}

I. The Test of Originality . . . . • • • 5 I

2. The Sources of Originality . . . • • • 53

(a) Observation of Nature $\quad \cdot \quad \cdot \quad \cdot \quad \cdot \quad \cdot 53$

(b) Consecutive Thinking $\quad . \quad \cdot \quad \cdot \quad \cdot \quad \cdot \quad \cdot 55$

(c) Companionship with Great Thoughts . . . 56

(d) Individuality . $. \quad . \quad . \quad \cdot 56$ 


\section{CHAPTER VII - The SubJect}

1. What is Due the Occasion . . . . . 58

2. What is Due the Subject . . . . . . 59

3. What is Due the Speaker. . . . . . . 60

\section{CHAPTER VIII - The TITLE}

1. An Attractive Title • • • • • • • 62

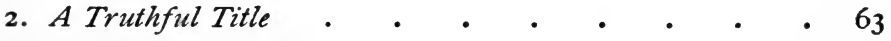

3. A Descriptive Title . . . . . . . . 63

CHAPTER IX - ThE MATERIALS

I. Relation to the Subject

2. Subordination to Subject . . • • • • • 67

3. Organization around the Subject • • • • • 68

(a) Reflection . . . . . • • . 68

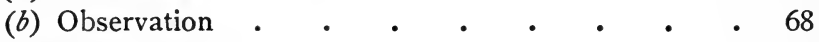

(c) Reading . . . . . . . . • • . 68

4. Management of Notes . . . • • • • 69

CHAPTER X-The WRITING

1. The Working Outline

2. The First Writing . . . . . . . $~ .74$

3. The Final Revision . • • • • • • 75

CHAPTER XI - The Grand Divisions of The Discourse

I. The Introduction

2. The Statement .

3. The Discussion .

4. The Peroration.

5. The Entire Discourse 
CHAPTER XII - How TO ACQUIRE AN ORATORICAL

\section{VOCABULARY}

1. Study of Oratorical Models

2. The Dictionary Habit

3. Synonyms and Antonyms .

4. Conversations on Words

5. Translating Languages

6. Study of Etymologv

7. Broad Usage

PAGE

86

86

87

90

CHAPTER XIII - Style in Public Discourse

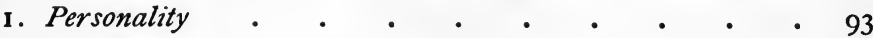

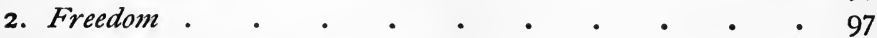

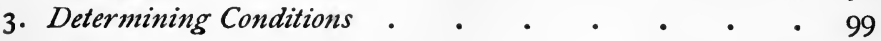

CHAPTER XIV - Digest OF RHETORICAL Rules

I. Diction

(a) Pure Words

(b) Proper Words .

(c) Precise Words .

2. Sentences.

Kinds

3. Essential Properties of Style

(a) Grammatical Correctness .

(b) Clearness

(c) Unity

4. Special Properties of Style

(a) Emphasis

(b) Force

(c) Harmony

(d) Vitality

(e) Figures of Speech

5. Variety of Expression-How secured

6. The Thought Divisions

7. The Whole Discourse 


\section{PART III-PREPARATION OF THE SPEAKER}

\section{CHAPter XV-Mental Preparation}

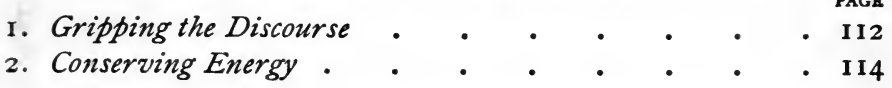

CHAPTER XVI-PREPARATION FOR EXPRESSION BY VOICE

I. Hygiene

2. Breathing.

3. Elements of Expression . . . . . . . . 118

(a) Quality . . . . . . . . . 1 II8

(b) Force

(c) Pitch

(d) Time

(e) Pause

(f) Emphasis

(g) Control.

4. Pronunciation

(a) Articulation . . . . . . . . . I24

(b) Accentuation . . . . . . . . . 126

(c) Enunciation . $\quad . \quad \cdot \quad \cdot \quad \cdot \quad \cdot \quad \cdot \quad$. 127

CHAPTER XVII - PREPARATION FOR EXPRESSION BY ACTION

I. Carriage .

2. The Head and Face. . . . . . . 132

3. Gesture . . . . . . • . . 133

CHAPTER XVIII - PREPARATION BY DRILL

i. General Suggestions .

2. The Will in Rehearsal . . . . . . . 140

3. Self-Criticism . . . . . • • • • I4I 


\section{PART IV - DELIVERY}

PAGE

CHAPTER XIX - Helps AND Hindrances in the Audience . • • • • . . $\quad$. 149

CHAPTER XX - FAcing the Audience

I. Just before Speaking

2. The First Moments of Delivery . . . . . 155

3. The Course of Delivery . • . • . • • 157

4. Ending the Discourse . . . . . . . 160

CHAPTER XXI - Do's AND DON'T'S FOR DISCOURSE . 162

\section{APPENDICES}

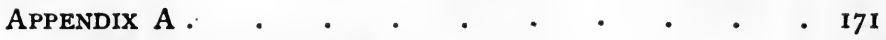

Outlines of Orations.

ApPEndix B .

Model Orations for Analysis and for Declamation.

Appendix C .

One Hundred Subjects for Orations, with Brief Hints for Treatment.

APPENDIX D .

One Hundred Subjects for Orations.

INDEX . 


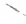




\section{FOREWORD}

THIS treatise aims to be suggestive, not exhaustive; practical, not theoretical; popular, not technical. With all this, it is believed that nothing essential to the public speaker in his effort to attract and hold an audience has been omitted or slighted. Fifteen years of experience have persuaded the author that, since comparatively few speakers have had opportunity to take a course in public speaking, such hints and helps as are here offered may find a welcome. The methods of the elocutionary manual have been discarded. Commonsense is a better substitute. The expositions and explanations are designed to be plain and straight-forward, assisting the speaker to find the way to the hearts of his audience.

The clearly marked divisions of the volume should add materially to its value as a text-book. The hortatory style here and there adopted is neither unusual nor unwarranted. The pupil as well as the teacher often needs a tonic. While its class-room use has been kept in mind, it is hoped that instructors will see the value 
of placing in the hand of the pupil a brief, lucid manual which will greatly lighten the burden of personal drill. The instructor will augment its value by indicating to the pupil such passages as he should study unassisted.

It is believed that the Appendices will add greatly to the suggestive and pedagogical value of the treatise.

$$
\text { J. B. E. }
$$

Pennsylvania Military College,

Chester, Pennsylvania,

January 5, rgo2. 
PART I

\section{THE THEORY OF SPOKEN DISCOURSE}


Thought once awakened does not again slumber. - CARLYLE, Heroes and Hero Worship.

If, then, a comprehensive definition of an orator were to be given, I would say that the speaker who justly claims this respectable name is he who, upon all subjects, shall be able to deliver his sentiments with accuracy, clearness, grace, and fluency, accompanied with a certain dignity of action.

By an orator I meant one who treated every subject which he wished to discuss, with a force and splendor of language that commanded admiration; one whose faculties comprehended all the treasures of knowledge which can enrich or inspire eloquence. Though this seems impracticable to us, . . . yet still it must be allowed to be within the compass of actual attainment. - CICERo, De Oratore. 


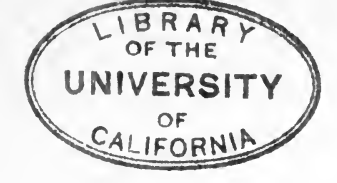

\section{HOW TO ATTRACT AND HOLD AN AUDIENCE}

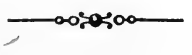

\section{PART I}

THE THEORY OF SPOKEN DISCOURSE

\section{CHAPTER I}

\section{THE NATURE OF PUBLIC SPEECH}

Thoughts that breathe and words that burn.

- Gray, Progress of Poesy.

Men speak to communicate ideas. All speech seeks to convey to the hearer a mental picture of that which is in the mind of the speaker - thought is alike its foundation and its completed result. Thus it is evident that public speech, whether intended to arouse, pacify, please, amuse, convince, or instruct, is always

\section{A Thought Instrument}

As such it must always be viewed in the light of the laws of thought. It is of primary importance, then, for us to examine the thought of every public discourse, since that is its chief characteristic. A full discussion of this part of our subject would involve the science 
and art of reasoning, called Logic; while to Rhetoric belongs the thorough treatment of the literary forms in which discourse is cast. ${ }^{1}$

A second element of public speech is

\section{Emotion}

Thought is colored by emotion, yet we must not confuse the one with the other. For example, a speaker purposes to denounce a public malefactor. The material which makes up the charges, and the facts adduced to support them, constitute the thought of the address; but the indignation, the passionate invective or appeal, of the speaker, communicated by him to his audience, indicate the emotion. How serious, then, is the importance of harmonizing your feeling with your thought when speaking before an audience, and this as much for the purpose of restraining undue excitement as in order to prevent a dull and monotonous presentation of the thought.

A third, though less apparent, element of public speech is

\section{The Will}

Various other names have been given to this element, but the last analysis shows all these to mean the same thing. The will it is that gives personality and convincing power to the address. Without it "thoughts" will not "breathe," and "words" will not "burn." 
Unless the will coöperate with both thought and feeling, the audience will master the speaker instead of the speaker his audience. The former is failure; the latter, success.

In a large sense, speech is the man. Given a message, personality makes the speaker, ${ }^{1}$ - not one, not two, but all of these phases of his three-fold individuality must come into play before the speaker can transform spectators into auditors.

The mastery of self in thought, in feeling, and in will is essential to mastering an audience; and your business before an audience, after having first made your subjectmatter a vital part of yourself, is to throw all the weight of your thought, feeling, and will upon your hearers, so as to reproduce in them your own state of mind. And this is true whether your theme be comic or tragic, persuasive or argumentative, descriptive or didactic. Never for one moment accept any other standard than that public speech rises in public respect and is truly successful in direct proportion as it reproduces in his hearers the spirit of the speaker. Think this deeply into your consciousness. 


\section{CHAPTER II}

\section{THE FORMS OF DISCOURSE}

She hath prosperous art

When she will play with reason and discourse, And well she can persuade.

- Shakespeare, Measure for Measure, Act I. Scene 2.

Rhetoricians recognize five forms of discourse, ${ }^{1}$ whether spoken or written: Description, ${ }^{2}$ Narration, Exposition, Argumentation, ${ }^{3}$ and Persuasion. The last two are sometimes regarded as one.

While these titles are really definitive, a somewhat closer examination into their nature and scope is necessary. ${ }^{4}$

\section{Description}

"Description is the portrayal of concrete objects, material or spiritual, by means of language," says Genung. Each word of this admirably explicit definition is significant, and separately is worthy of the student's notice.

${ }^{1}$ For full discussion see Working Principles of Rhetoric, Genung, pp. 475-662.

2 See Highways of Literature, Pryde, pp. 152, 153.

${ }^{3}$ See Principles of Argumentation, Baker.

4 Some practical hints on the rhetorical use of the Forms of Discourse are offered in Chapter XIV. 
In order to accurate, vivid, and attractive description, six things are necessary.

(a) Establish a point of view and maintain it. - Do this so consistently that your hearers must understand and adopt your attitude toward the object or idea described. This may be compared to establishing a scale of inches to miles in map drawing.

(b) Briefly and comprehensively outline the whole scene before describing it in detail. - A vivid initial survey will give tone and spirit to the entire portrayal.

(c) Relentlessly cut out all ideas and words not necessary to produce the effect you desire. - Details in a mental picture either help or hinder. Be sure they do not hinder, for they cannot be passively present in any discourse.

(d) Give vivid prominence to important characteristics. - That is, to those things which give an object its individuality, and so distinguish it from all different objects. Learn a lesson from the poster-artist.

(e) Follow a natural, logical, and climactic order in description. - One feature introduced out of its order will distort the picture you are painting for your audience. Hold things in proportion.

(f) Make a powerful and effective summary in presenting the general view at the close of the portrayal. - First and final impressions remain the longest. The mind may be trained to take in the characteristic points of a subject, so as to view in a single scene, action, experience, or character, a unified impression of the whole. 
It is necessary to gain this "bird's-eye view" before you can select fitting words wherewith to portray your subject effectively. In other words, a clear and sharply outlined picture of what you wish to describe must be in your mind's eye before you can transfer it to your auditors.

This clear, unified mental picture often suggests a striking epithet or a figure of speech, and hence effective speakers often employ epithets and figures in description.

\section{Narration}

The recounting of the particulars of an event, or of a series of events, in the order of occurrence, is called narration. Sometimes this order is changed with the purpose of making a more powerful impression upon the hearer. Narration is closely related to description, each frequently being made auxiliary to the other.

(a) Be sure you see the end from the beginning. - This is fundamental to all narration.

(b) Subordinate the minor to the major points of interest.

(c) Keep the application of the narration in mind.Particularly must this be observed if the narrative is used as an illustration, else the story may defeat its own end by absorbing all the interest, leaving the motive for its introduction uncertain.

(d) Narration must preserve its forward movement at all hazards. - Digressions are fatal. Narration deals 
with events, and when these lag, failing to follow each other with variety, interest, and surprise, or when the "point" is revealed too soon, a dispiriting anti-climax results and the hearer loses interest.

\section{Exposition}

This may be defined as the clear and simple setting forth of what a thing really is. It does not deal with reasons or with arguments, but confines itself to inquiries as to what things mean, as to how they differ from other things, and as to questions of fact.

For the purposes of this treatise it is enough to note the four lines along which exposition may proceed.

(a) By definition, exposition attempts so to outline a subject as to distinguish it from all objects not bearing the same name. This process of discrimination, of showing just how the subject of definition differs from other subjects with which it might be confused, is fundamental to effective discourse.

(b) By classification, exposition seeks to place the subject in the class, order, genus, and species in which it belongs. This process is synthetic.

(c) By division, which is classification reversed, exposition so divides the subject as to bring clearly to view its parts, severally as well as in relation. This process is analytic.

(d) By generalization, exposition attempts to make a broad, general statement of the subject so as to present it in a single view. 
When illustration by example is used according to the laws of narration, it becomes an efficient aid to exposition. It should be remembered that illustration is not argument, though argument often appeals to examples to support its contention.

To master the process of exposition is to become a clear thinker. "I know, when you do not ask me," 1 replied a gentleman upon being requested to define a highly complex idea. Now some ideas defy explicit definition; but no mind should take refuge behind such exceptions, for where definition fails, other forms succeed. Sometimes we feel confident that we have perfect mastery of an idea, but when the time comes to express it, the clearness becomes a haze. Exposition, then, is the test of clear understanding. To speak effectively you must be able to see your subject clearly and comprehensively, and to make your audience see it as you do. It is the basis of all sound argumentation.

\section{Argumentation}

This we define as the process of producing pure conviction. For the accomplishment of this end argumentation proceeds according to the laws of Logic - defined by $\mathrm{McCosh}$ as "the science of the laws of discursive thought" $;{ }^{2}$ and by Whately as "the science, and also the art, of reasoning." 3

1 Working Principles of Rhetoric, Genung, p. $56 \mathbf{r}$.
2 Logic, p. I.
3 Logic, p. $\mathbf{r}$. 
The very name "logic" has to many an awful sound - they covet its power, but are frightened by its supposed intricacies. In point of fact, nothing is simpler than common-sense reasoning. A host of hair-splitting processes and learned terms are doubtless valuable to the specialist ; but for the orator's purpose - and let it be remembered that for his uses alone these thoughts are presented - an acquaintance with a few simple forms of reasoning is all that is necessary. The logic of common sense "is modest, plain, and unsophisticated. It sees with everybody's eyes, and hears with everybody's ears. It has no capricious distinctions, no perplexities, and no mysteries. It never equivocates, and never trifles. Its language is always intelligible. It is known by clearness of speech and singleness of purpose." 1

There are two main ways of handling argumentation: first, building up an argument; second, tearing down an argument.

\section{BUILDING UP AN ARGUMENT}

(a) Getting at facts. - This process of investigation is closely allied to exposition, upon which, as we have just seen, argumentation depends for its clearness and its accuracy.

There are four ways of getting at the facts necessary to an argument.

1 Public Speaking and Debate, Holyoake, p. 15. 
(I) By intuition. - For example, you intuitively know that you are yourself, and not somebody else. It needs neither observation, testimony, nor argument to convince you of this; it is one of the earliest facts of your consciousness.

(2) By personal observation or investigation.

(3) By the testimony of trustworthy witnesses.

(4) By appeal to competent authorities.

(b) Drawing conclusions from facts. - This process is called induction. By it facts are not only gathered, but also put together in such a manner as to produce in the mind a belief concerning those facts. The methods of induction employed by Dr. A. Conan Doyle's inimitable Sherlock Holmes are capital examples of this style of reasoning. Holmes always secured as many wellattested facts as he could, then inferred other probable facts, and from them all constructed a working theory. To this theory (the logicians would call it an hypothesis) he clung until the discovery of additional data proved or disproved the correctness of his supposition. This idea of forming an hypothesis, a shrewd guess, a working theory, is at the basis of all induction.

Bear in mind that an earnest inquirer is always asking the meaning of things about him. How may he draw conclusions, or infer explanations, from the facts he possesses? There are several simple ways.

(I) He may argue from a known cause to its probable effect.

This method the logicians call arguing a priori. For 
instance, when a prosecuting attorney clearly proves that there existed in the mind of a man charged with murder, a motive sufficiently strong to induce him to commit the crime, a strong inference against the accused has been established.

(2) He may argue from a known effect back to its probable cause.

This process the logicians term arguing a posteriori. For example, an orator who wishes to prove that the liquor traffic is an evil may simply point to its effects. The argument a posteriori judges a tree by its fruits.

Genung has thus summarized the legal tests for these two forms of induction:-

"Concerning any argument involving cause and effect, three facts must be established, by way of test, before it can be regarded as conclusive. It must be shown :-

That an actual cause exists;

That it is sufficient to produce the effect contemplated; That opposing circumstances or probabilities are not sufficient to hinder its working." 1

(3) He may draw a conclusion to which circumstances strongly point.

When surroundings strongly indicate a fact, and yet there is no positive corroborative testimony, such indications are called circumstantial evidence.

It is plain that indications cannot compare with posi-

${ }^{1}$ Working Principles of Rhetoric, Genung, p. 610. 
tive facts as weighty evidence; but when the signs are many and pointed, the argument becomes powerful. As an instance, the circumstances point to Sir Philip Francis as the probable author of The Letters of Junius, but the evidence is not strong enough to establish his alleged authorship as a fact.

The prosecuting attorney uses circumstances to argue a conclusion in the following manner, whether he puts it in such definite form or not:-

The murderer frequently carries blood stains on his clothes ;

The accused has such stains upon his clothes;

Inference: The accused is the murderer.

The murderer must have been in the neighborhood at the time of the murder;

The accused was seen in the neighborhood both before and after the time of the murder;

Inference: The accused is the murderer.

The murderer must have walked through red clay to reach the barn where the victim was murdered; The accused had lumps of red clay upon his boots; Inference: The accused is the murderer.

Examples might be multiplied indefinitely. It is sufficient to observe that when inferences of this kind are supported by others, the result is called cumulative evidence, and may produce moral certainty, even when no direct testimony can be secured. 
(4) He may forecast a future happening, or justify a course of conduct, from past experiences.

As an example take the statement that those who have taken foolish risks have generally met disaster. The irresistible inference is against taking foolish risks. This kind of induction is most frequently used in urging moral considerations and in exhorting to certain courses of conduct.

One of its forms is known to logicians as argument a fortiori. Thomas Jefferson used it thus effectively : "Sometimes it is said that man cannot be trusted with the government of himself. Can he, then, be trusted with the goverment of others?"

Other excellent examples are to be found in several of Christ's sermons.

"If a son shall ask bread of any of you that is a father, will he give him a stone? Or if he ask a fish, will he for a fish give him a serpent? Or if he shall ask an egg, will he offer him a scorpion? If ye then: being evil, know how to give good gifts unto your children, how much more shall your heavenly Father give the Holy Spirit to them that ask him ?"1

"If then God so clothe the grass which is to-day in the field, and to-morrow is cast into the oven; how much more will he clothe you, O ye of little faith ?" 2

(5) He may argue from analogy. That is, he may draw a parallel between two facts or sets of facts, and argue that because there are admitted points of

${ }^{1}$ St. Luke xi. I I-I 3.

2 St. Luke xii. 28. 
likeness, other similarities probably exist. Analogy can never produce certainty; but at best only probability. Even that probability is destroyed when things not alike are assumed to be similar. A fine example of its most discriminating use is Professor Henry Drummond's treatise, Natural Law in the Spiritual World. The whole course of argument is from analogy.

Modern thinkers agree that the chief value of analogy is for purposes of illustration.

(c) Inferring facts from general principles. - This process, known as deduction, is the exact opposite of inductive argument. Induction, as we have seen, considers separate facts, unites them, and draws from them a conclusion or general principle. Deduction begins with a general, admitted truth and infers from it the facts upon which the truth, the principle, depends.

We also saw that a working theory or hypothesis is the basis of induction; but the basis of all deductive reasoning is (I) the syllogism. It is more simple than might be inferred from the statement that it cannot be satisfactorily defined in few words. We may, however, discover its character by examining its structure.

\section{Syllogism}

Major Premise: All men must die.

MiNor Premise: John is a man.

Conclusion: Therefore, John must die.

It will be seen at once that the major premise makes a general statement which it declares to be a truth 
covering all cases - "All men must die." The minor premise makes a particular statement - "John is a man" - which covers one case plainly included in the general class of the major premise - "All men." Since what is affirmed of a class is true of every member of that class, the conclusion follows, "John must die."

It is evident that the mind seldom reasons thus formally and consciously. Yet this is "the inner framework of every argument that is founded on a general truth." In everyday language the orator might express the syllogism in this contracted form: "Since all men must die, it is evident that John can look forward to no different fate." Now it is self-evident that "John is a man," so the orator would omit stating this as a minor premise. When either the major or the minor premise is so self-evident that one of them may be omitted, the contracted form (as above) is called the (2) syllogism in enthymeme. This is peculiarly the argument of the orator. Jesus Christ, who spoke "as never man spake," frequently employed this contracted syllogistic form. The Beatitudes, recorded in the fifth chapter of St. Matthew, are beautiful examples.

Expand the declaration, "Blessed are the merciful, for they shall obtain mercy," and you have this syllogism :-

Major Premise: They who obtain mercy are blessed. Minor Premise: The merciful obtain mercy.

Conclusion: Therefore, the merciful are blessed. 
Care must be exercised in constructing the syllogism in enthymeme. The danger lies in assuming that the omitted premise is self-evident, - often it is obvious to only the speaker, and thus the argument is to the hearer no argument at all. ${ }^{1}$

Clearly, it is most important that the premises should be strictly true if we wish the conclusion to be sound. Many orators recognize this by first publicly demonstrating the truth of either one or both of their premises before asserting the conclusion. This is called the (3) syllogism in enlargement. It may extend through one paragraph or through many. Sometimes it is made the framework for an entire discourse.

Any absurdity may be proven by admitting a false premise as true. Take, for example, Shakespeare's famous line :-
Major Premise: "All that glitters is not gold." 2
Minor Premise: Gold glitters.
Conclusion: Therefore gold is not gold.

If the dramatist had said: Not all that glitters is gold, the major premise would have been correct, and no false conclusion could have been drawn therefrom.

1 The specimens of inductive argument given on pp. 14, 15 , differ from the contracted syllogism (the syllogism in enthymeme) in the fact that the reason given as the basis of the induction is not a ground of proof, but a mere indication; in the syllogism the premise is part of the proof of the conclusion. See Logic, McCosh, pp. 16I-I63 ; Logic, John Stuart Mill, Book III. Chapter 8.

2 Merchant of Venice, Act II. Scene 6. 
Sometimes the orator will expand the syllogism into a chain, called sorites.

$A$. The prisoner deliberately administered arsenic to the man who died.

$B$. He who deliberately administers poison with fatal results is guilty of murder in the first degree.

$C$. He who is guilty of murder in the first degree should be executed.

$D$. He who is executed should be executed privately.

$E$. Therefore, the prisoner should be executed privately.

It is evident that this chain is a contraction of the following four syllogisms:-

\section{FIRST SYLLOGISM}

Major Premise (understood): He who administers arsenic administers poison.

Minor Premise ( $A$ above): The prisoner administered arsenic to the man who died.

Conclusion: Therefore, the prisoner administered poison to the man who died.

\section{SECOND SYLLOGISM}

Major Premise ( $B$ above): He who deliberately administers poison with fatal results is guilty of murder in the first degree. Minor Premise ( $A$ above, and conclusion of first syllogism): The prisoner deliberately administered arsenic poison to the man who died.

Conclusion: Therefore, the prisoner is guilty of murder in the first degree.

\section{THIRD SYLLOGISM}

Major Premise ( $C$ above): He who is guilty of murder in the first degree should be executed.

Minor PREMise (conclusion of second syllogism): The prisoner is guilty of murder in the first degree.

CoNCLUSION : Therefore, the prisoner should be executed. 


\section{FOURTH SYLLOGISM}

Major Premise ( $D$ above): He who is executed should be executed privately.

MINoR PREMISE (conclusion of third syllogism): The prisoner should be executed.

Conclusion ( $E$ above): Therefore, the prisoner should be executed privately.

A playful contracted example of sorites " is seen when the Thracians let loose a fox on a frozen river to try the ice. Reynard put his ear down and seemed to say, 'Whatever makes a noise moves; what moves is not frozen hard; that which is not hard is liquid; liquid will bend under weight; therefore, if I perceive close to my ear the sound of water, it is not frozen, and the ice is too weak to bear me." 1 The Thracians followed the reasoning of the fox, and did not attempt to cross on the ice. Of course some of Reynard's premises must not be pressed too far.

To enter into all the possible variations of the syllogism is the work of Particular Logic, and would be useless to the general student. ${ }^{2}$

1 Art of Extempore Speaking, Bautain, p. 301.

${ }^{2}$ For those who would make further study of the syllogism the following rules are given: I. In a syllogism there should be only three terms. 2. Of these three only one can be the middle term. 3. One premise must be affirmative. 4. The conclusion must be negative if either premise is negative. 5. To prove a negative, one of the premises must be negative.

Summary of Regulating Principles: I. Terms which agree with the same thing agree with each other; and when only one of two terms agrees with a third term, the two terms disagree with each other. II. "Whatever is affirmed of a class may be affirmed of all the members of that class," and "Whatever is denied of a class may be denied of all the members of that class." 
(d) The joint inductive and deductive method. - It is enough to say here that no reasoner should confine himself to a single logical method. Let him learn to use all methods with equal accuracy and facility.

\section{BREAKING DOWN AN ARGUMENT}

The orator frequently finds himself set in opposition to another speaker whose arguments he must either surpass or refute. How to do the one no instruction can tell him; the process of refutation, however, may be definitely studied. Sometimes, but not always, will it suffice simply to present truth and depend upon its force to demolish the opposite position. Often more aggressive measures are needed.

Comparatively few hearers who are actively against you can be won over to be your partisans; much of your effort must be to cause men to get off the fence, and stay off, - on your side. Now and then, however, the orator's victory will depend upon winning over a stubbornly adverse auditor. It is related of the great advocate, Rufus Choate, that: "In one jury address of five hours, he hurled his oratorical artillery for three of them at the hard-headed foreman, upon whom all his bolts seemed to be spent in vain. At last the iron countenance relaxed, the strong eyes moistened, and Choate was once more master of the situation." 1

There are four ways to break down an argument, whether it has been definitely stated by an opponent, or

1 Oratory and Orators, Matthews, p. 372. 
you suspect it to exist in the minds of those you wish to convince. All of these methods should be employed, but which of them shall predominate will depend upon your object.

(a) The orator may employ simple rebuttal, and meet fact with fact, argument with argument.

(b) He may offer no arguments in rebuttal, but, disregarding the opposite view, simply depend upon the power of his own affirmative reasoning.

(c) He may show that no position other than his own can be reasonably held.

This third result may be attained by :-

(I) Reducing the alternative proposition to an ab. surdity (reductio ad absurdum).

The speaker proceeds by supposing, for the sake of his argument, that the opposite of his reasoning is correct. This supposition is then followed out logically, until it becomes evident that the assumed position is absurd. There is room here for the play of a biting wit, but the reasoner's position must be well taken if he would not be retorted upon in kind.

Example: A man is charged with having written a treasonous article. The defense admits, for the sake of the argument, that the sentiments are treasonous, but shows that every one of them is contained in the Declaration of Independence and in the Constitution of the United States, - this is sufficient to prove the absurdity of the charge. 
(2) Offering either horn of a dilemma.

This method divides the opposite ground into the only two possible positions, and then confutes each by convincing argument. The result is that the reasoner's position is the only one left, and therefore must be adopted.

A familiar example is the following: The Roman soldiers declared that while they were sleeping the Disciples came and stole Christ's body from the tomb. Now the soldiers were either asleep or awake. If they were asleep, were they competent to testify that the body was stolen? Sleeping sentinels deserve death. If they were awake, why did they not oppose the theft? They made no outcry. Therefore, the testimony of the soldiers is false, and Christ is risen from the dead.

There is great danger of false reasoning in employing the dilemma. "If the dilemma is accurate in form, the conclusion follows, and the only way of meeting it is by showing that the alternatives in the premises are not exhaustive - that there may be another supposition." 1

The well-known dilemma in Don Quixote is based upon false reasoning. In brief it is this: At one end of a bridge stood a courthouse, at the other a gallows. Every one who sought to cross the bridge was made to answer two questions, under oath, - Where are you going? What is your object in going there? If he swore truly, he was permitted to go free. If he swore falsely, he was to be hanged on the gallows at the other end of the bridge. 
Now a man came to the courthouse and made oath that he was going to the other end of the bridge, and that his object in going was that he might be hanged. The honest Sancho Panza was in a dilemma: if he hanged the man, he must hang him for telling the truth; if he made him go free, the man would deserve death for false swearing.

A false dilemma may be answered by another. "An Athenian mother said to her son, 'Do not engage in public affairs ; for if you do what is just, men will hate you, and if you do what is unjust, the gods will hate you.' This the son rebutted by the following retort: 'I ought to enter into public affairs; for if I do what is unjust, men will love me, and if I do what is just, the gods will love me.' ",

(3) Logical elimination is the third method.

This form of reasoning states "all the possible aspects of the question, then proceeds to eliminate, one by one, until only the one tenable aspect is left." 1

The "Unjust Steward" 2 reasoned by logical elimination when he was called to give an account of his stewardship: “Then said the unjust steward within himself, What shall I do? for my lord taketh away from me the stewardship: I cannot dig; to beg I am ashamed. I am resolved what to do," etc. But he failed, as many weak reasoners do, to enumerate all the possible courses of action.

1 Working Principles of Rhetoric, Genung, p. 625.

2 St. Luke xvi. I-8. 
The fourth method of destructive argument remains :-
(d) He may point out a fallacy in the opposite position.

A fallacy is any error which makes reasoning unsound and inconclusive. A fallacious conclusion is also called a fallacy.

Whately includes the idea of deception in his definition when he says that it is " any unsound mode of arguing, which appears to demand our conviction, and to be decisive of the question in hand, when in fairness it is not."

The orator must be as quick to discern weakness in his own reasoning as in that of others. Stupendous issues have gone wrong because of a single undetected fallacy! An elaborate structure of argument will totter to its fall if its foundation is proven to be fallacious.

A keen mind may avoid or detect a fallacy without possessing a knowledge of formal logic. The list of possible fallacies is long and intricate, but only a few fundamental errors in reasoning need here be noted.

(I) A false conclusion is sometimes drawn from true premises.

Logicians call this a non sequitur - it does not follow; the premise will not warrant the conclusion; as:-

Major Premise: All men are animals.

Minor Premise: A four-footed animal is not a man.

Conclusion: Therefore, a four-footed animal is not an animal.

Though no one could dispute the truth of the premises, still they are not logically related, and the conclusion does not follow. The true conclusion is -

Therefore, not all animals are men. 
Again :-

Major Premise: All free men love liberty.

Minor Premise: These men are not free.

Conclusion: Therefore, these men do not love liberty.

The fallacy lies in presuming that only free men love liberty; the conclusion is not sustained by the premises.

(2) Words are sometimes used in double senses.

This ambiguity is very specious at times, and can be met by those only who are well acquainted with synonyms. For example, note the double use of the idea careless in the following syllogism:-

Major Premise: All men who have no cares are happy.

Minor Premise: Slovenly men are careless.

ConClusion: Therefore, slovenly men are happy.

Major Premise: All cold is expelled by fire.

Minor Premise: This man has caught cold.

Conclusion: Therefore, his cold can be expelled by fire.

Sometimes this fallacy is ridiculed and exposed by an absurd illustration, based upon a pun, as :-

Major Premise: A missionary is one sent.

MiNor PREMISE: The usual missionary contribution is one cent.

Conclusion: Therefore, the usual missionary contribution is a missionary.

Or the absurdity may be extended to a chain of puns, as :-

A sheet of ruled paper is an ink-lined plane. An inclined plane is a slope up.

A slow pup is a lazy dog.

Therefore, a lazy dog is a sheet of ruled paper.

This also humorously illustrates the fallacy of substitution of terms, in which one term is deceptively substi- 
tuted for another until the argument is thus speciously led away from its true conclusion.

(3) Begging the question is the most common of all fallacies.

The logicians term it petitio principii. It consists in offering as proof, the very fact you propose to prove, thus evading the necessity of offering proof. For example: Macaulay's History of England is an authentic history, because it contains an accurate account of the events of English history. We know that this account is accurate because it is contained in so authentic a history as Macaulay's.

One of Molière's comedies contains a playful example when it is said that opium produces sleep because of its soporific qualities.

(4) When this begging or evading of the question is pushed farther, so as to reason in a circle, it is called the vicious circle.

It may be illustrated thus:-

Proposition: Men ought not to steal:

$A$. Because it is wrong.

$B$. It is wrong because it is contrary to the Moral Law.

C. It is contrary to the Moral Law because it is forbidden in the Holy Scriptures.

D. It is forbidden in the Holy Scriptures because it is contrary to God's will.

$A$. It is contrary to God's will because it is wrong.

The more extended the circle, and the more involved the statement, the more difficult it is to detect this kind of fallacy. 


\section{(5) Imperfect enumeration is also very common.}

It consists in drawing a conclusion without taking into account all the facts, as, it might be stated that all isolated inland bodies of water are fresh. In proof, every such lake or sea might be mentioned, except the Caspian Sea and the Dead Sea, which are salt, and therefore break down the assertion. Insufficient enumeration is a common error of the untrained mind. Indeed, good natural reasoners are few, for it is generally true that education is necessary to protect the mind from error.

\section{Persuasion}

Persuasion is the art of moving to action by means of entreaty, reason, or emotional appeal.

Persuasion is a broader term than Argumentation. The latter addresses itself purely to the intellect; persuasion goes farther, and usually employs argument merely as the basis of an emotional appeal with which it hopes to move the will to action. Sometimes, however, all address to reason is discarded, and a purely emotional appeal is made, likewise with intent to bring about action. Persuasion may even go so far as to disregard truth, and strive to carry the citadel of the will by assault, marshaling prejudice, imagination, and emotion to accomplish the result. When both forms of discourse are skillfully united, each effectively complements the other, and jointly they constitute the most formidable weapon of the orator. Nor is the use of persuasion a confession of weakness upon the part of 
argumentation; it is rather a recognition of the qualities of human nature - factors never to be disregarded by him who would attract and hold an audience. If argument challenges the respect of those who hear, persuasion adds the human touch to cold reason, turns the marble to warm life, and transfuses respect with sympathy.

Persuasion has three aspects :-

(a) The address to the intellect. - This has been sufficiently outlined under Argumentation.

(b) The appeal to the emotions. - It is no disrespect to the general audience to say that hearers respond much more readily to emotional than to intellectual appeals. Indeed, in all mankind the emotions are the springs of action. The public speaker is therefore not slow to see the importance of understanding the nature and the management of this powerful force. ${ }^{1}$ But it is with the orator's influence upon the feelings, not with their psychological nature, that we have here to do, so that a few practical observations will be sufficient.

(I) The orator himself must feel before he can arouse the emotion of others. ${ }^{2}$ Powerful emotion gives birth to eloquence. It is related of Crœsus ${ }^{3}$ that his only living son was dumb. When Cyrus captured Sardis, a soldier, not recognizing Crœsus, was about to give the

1 An admirable discussion of the Emotions will be found in Gordy's Psychology, in loco.

2 See p. 4.

3 Ancient History, Rollin, Book IV. Chap. I. Art. I. 
king a blow upon the head. The emotion of fear and love for his father so wrought upon the young prince that he "broke the string of his tongue, and cried out, "Soldier, spare the life of Crœsus!'” Thus, back of all emotional appeal stand the two forces, real emotion in the speaker, ${ }^{1}$ and his own personality. ${ }^{2}$

(2) The natural feelings of the audience must be set to work. That is, no new emotions can be imparted to them; but "Persuasion implies that some course of conduct shall be so described or expressed as to coincide or be identified with the active impulses of the individuals addressed, and thereby command their adoption of it by the force of their own natural dispositions." 3

To this end the orator must know his audience." Antony knew "what chords to strike in a mob"; Brutus did not.

Handing to Guildenstern a musical instrument, Hamlet requests him to play upon it. The courtier protests that he cannot, whereupon Hamlet complains :-

"Why, look you now, how unworthy a thing you make of me. You would play upon me; you would seem to know my stops; you would pluck out the heart of my mystery; you would sound me from my lowest note to the top of my compass: and there is much music, excellent voice, in this little organ; yet cannot you make it speak. 'Sblood, do you think I am easier to be played on than a pipe? Call me what

1 See p. 157 .

2 See p. 93.

3 The Senses and the Intellect, Bain, p. 542.

4 See p. 149. 
instrument you will, though you fret me, you cannot play upon me." 1

Guildenstern's task was not an easy one, and he failed of his purpose; yet this is just the work cut out for the persuasive orator. In his essay on Eloquence, Emerson expresses much the same idea:-

"Him we call an artist who shall play on an assembly of men as a master on the keys of a piano, - who, seeing the people furious, shall soften and compose them, shall draw them, when he will, to laughter and to tears. Bring him to his audience, and, be they who they may, - coarse or refined, pleased or displeased, sulky or savage, with their opinions in the keeping of a confessor or with their opinions in their bank safes, he will have them pleased and humored as he chooses; and they shall carry and execute what he bids them."

(3) The causes of feeling must be presented. "We should feel grateful," is in no sense an appeal to feelings; the vivid presentation of the causes of gratitude is such an appeal. Love and hate, gratitude and revenge, generosity and cupidity, admiration and contempt, pathos and humor, sublimity and beauty, cannot be called forth, in either the speaker or his audience, by mere will power. However, they can be evoked by the will calling up a picture of the causes which lead to particular emotions. To be told that such and such scenes are sublime will not arouse the sense of sublimity in an audience; but painting a lofty and glowing

1 Hamlet, Act III. Scene 2. 
word-picture, dealing with vast, powerful, and impressive objects, will arouse that feeling. The lovable, hateful, admirable, humorous, beautiful, or whatever, characteristics of an object should be set forth in all their native colors, and then you may trust to causes to produce effects. But do not fail to guide the causes.

The converse of this proposition is equally true: to get rid of an emotion it is idle to say, "You must not feel thus," but another and stronger emotion should be relied upon to displace the first. The best way to dispel the anger of an audience is to give them something more absorbing, pleasing, humorous, to think about.

(c) The appeal to the will is, as we have seen, made through the emotions or through the intellect and the emotions jointly. To arouse emotions for their own sake may impart a certain pleasing titillation, and is often the sole object in some sorts of demonstrative oratory, but such an end is entirely foreign to persuasion. Here the great end is so to guide thought and feeling, jointly or singly, as to secure action. The skillful persuasive orator will take advantage of every sigh, tear, chuckle, and guffaw in his audience to cause them to adopt his view and act upon it. Antony was not content to read Cæsar's will, exhibit Cæsar's mantle, dwell upon Cæesar's virtues; he did not leave off working upon the mob until he saw that their own base passions would lead them on to deeds of furious vengeance against the conspirators, and until with one voice they cried :- 
"Revenge! About! Seek! Burn! Fire! Kill! Slay! Let not a traitor live!" 1

Then, well satisfied with his work, Antony soliloquizes:-

"Now let it work. - Mischief, thou art afoot.

Take thou what course thou wilt." 2

This rousing to action, unworthy though it often may be, is the hall-mark of pure oratory. The speech that leads men up to the gate of endeavor and cannot move them to press through its portals, is a failure, if action has been its object. Name the preachers, the political orators, and the agitators, whose names are on men's lips, and you will find that they are the orators who know the art of moving men to abandon their pampered sins and their cherished causes in order to adopt the life and thought the orator has urged.

\section{Summary}

It has been already intimated that all five of these forms of discourse may be used in public speech, but it must not be forgotten that they are seldom to be used singly, - they may be combined and even modified to suit your special end. The tone, the temper, the spirit of theme, orator, and occasion must determine which form of discourse shall dominate. The great danger is of failure to keep one form so evidently predominant that the hearer must recognize the use of the others as merely auxiliary.

1 Julius Cresar, Act III. Scene 2.

2 Ibid. 


\section{CHAPTER III}

\section{THE KINDS OF PUBLIC DISCOURSE}

I take it to be a principal rule of life not to be too much addicted to any one thing. - TERENCE.

All kinds of public discourse may be included under four heads: Impromptu Speeches, Extemporaneous Ad. dresses, Declamations, and Orations.

\section{Impromptu Speeches}

Such are addresses delivered without preparation. The ability to think on one's feet is a gift, or attainment, at once to be coveted and to be feared. Bismarck used to call it "the fatal gift of eloquence," referring to the fact that those who possess this ability are strongly tempted to neglect preparation, and so to substitute an array of words for real thought. There are occasions, however, when an impromptu speech is most opportune; but rarely, if ever, can the need of the hour be met except by one who has previously patiently trained himself in the fundamentals of prepared address. He may seem to be spinning the magic web of eloquence from the "thin, invisible air," but in reality he is drawing from the carefully husbanded resources of past thought 
and reading, and only the occasion was needed to weave the material into effective form.

As a rule, impromptu speakers are inexact in thought and in expression, freely indulging in glittering nothings, and in "epigrams made at the expense of truth." The successful few, who really speak ably "on the wing of occasion," have learned to do so through the discipline of prepared address.

\section{Extemporaneons Addresses}

The word extemporaneous has changed its meaning. It is now used to designate any production, such as a sermon, address, or argument, which has been carefully thought out before delivery, and yet not committed entirely, if even in part, to writing. The speaker may refer to briefs or notes during the delivery of the address. It is well to cultivate the art of speaking without notes, for the results - benefit to the memory, directness and force of presentation, and general impression upon the audience - fully compensate for the added labor of preparation involved.

\section{Declamations}

This kind of public effort may be defined as a selection of prose or poetry, recited in public from memory. Some writers distinguish as declamations only such selections as are either political or forensic, designating all descriptive and poetic material as recitations. Ora- 
tions pronounced by others than their writers are really declamations, and all speaking in the drama is either declamatory or recitative.

\section{Orations}

An oration is a formally prepared and dignified discourse, delivered upon a special occasion, upon a subject of personal import to the hearer, and appeals primarily to the emotions.

Two points of this definition require emphasis, both here and in succeeding sections.

(a) The truth of the oration is of personal import to the hearer. - Failing of this, the discourse becomes a mere speech, moving no life-interests and impelling to no action. Therefore the personal aim and tone determine its subject, matter, and style.

(b) Since it is personal, oratory appeals primarily to the emotions. - To be sure, it speaks also to the intellect, and the greater number of orations design to move the will; but it is in its appeal to the emotions that the oration seeks to reach the volition, so that herein also oratory essentially differs from mere public speech.

Many have deemed this emotional appeal to be so important that they have narrowed oratory down to such public speech as has for its end persuasion. Thus Aristotle conceived oratory to be "the faculty of finding all the means of persuasion on any subject." Important a part as persuasion admittedly plays in the great majority of orations, the philosopher's dictum is 
not a definition, for many orations employ no persuasive means whatsoever.

It will be seen, then, that we must carefully adhere to our definition when considering the oration. Whether the form adopted by the orator is that of extemporaneous discourse or of the carefully written and committed production, the distinctions just noted must be held in mind. The public patiently endures many spoken essays and disquisitions masquerading as orations, which lack the essential characteristics of oratory. Especially is this true of college platform efforts.

The distinction between the address to the intellect and the appeal to the emotions may be illustrated as follows :-

"A reasoner," Professor Genung says, "who is endeavoring to demonstrate that the planet Mars is inhabited is indeed handling an intricate argumentative problem; he is seeking to find a truth, or at least a balance of probability; but if he solves the problem ever so clearly, the answer cannot in the smallest degree appeal to the hearer's will." It may challenge his interest and excite his thought, but it bears no personal relation to him and cannot arouse a single emotion. Compare with this a notable episode in Daniel Webster's career, graphically described by Dr. Chauncey A. Goodrich.

In the celebrated "Dartmouth College Case," after Mr. Webster had exhaustively expounded the law governing private corporations, he ended with the 
following peroration, "the most remarkable ever delivered in a purely civil suit involving no personal rights" :"This, sir, is my case. It is the case, not merely of that humble institution, it is the case of every college in the land. It is more. It is the case of every eleemosynary institution throughout our country - of all those great charities formed by the piety of our ancestors, to alleviate human misery, and scatter blessings along the pathway of life. It is more! It is, in some sense, the case of every man among us who has property of which he may be stripped, for the question is simply this: Shall our State legislatures be allowed to take that which is not their own, to turn it from its original use, and apply it to such ends or purposes as they in their discretion shall see fit?

"Sir, you may destroy this little institution; it is weak; it is in your hands! I know it is one of the lesser lights in the literary horizon of our country. You may put it out. But, if you do so, you must carry through your work! You must extinguish, one after another, all those greater lights of science, which, for more than a century, have thrown their radiance over our land!

"It is, sir, as I have said, a small college, and yet there are those who love it."

"Here," continues the narrator, "the feelings, which he had thus far succeeded in keeping down, broke forth. His lips quivered; his firm cheeks trembled with emotion; his eyes filled with tears, his voice 
choked, and he seemed struggling to the utmost simply to gain that mastery over himself which might save him from an unmanly burst of feeling. I will not attempt to give you the few broken words of tenderness in which he went on to speak of his attachment to the college. The whole seemed to be mingled throughout with the recollections of father, mother, brother, and all the privations and trials through which he had made his way into life. Every one saw that it was wholly unpremeditated, a pressure on his heart, which sought relief in words and tears.

"The court-room during these two or three minutes presented an extraordinary spectacle. Chief Justice Marshall, with his tall and gaunt figure bent over, as if to catch the slightest whisper, the deep furrows of his cheek expanded with emotion, and his eyes suffused with tears; Mr. Justice Washington at his side, - with his small and emaciated frame, and countenance more like marble than I ever saw on any other human being, - leaning forward with an eager, troubled look; and the remainder of the court, at the two extremities, pressing, as it were, toward a single point, while the audience below wrapping themselves round in closer folds beneath the bench, to catch each look and every movement of the speaker. If a painter could give us the scene on canvas, - those forms and countenances, and Daniel Webster as he stood there in the midst, it would be one of the most touching things in the history of eloquence." 


\section{CHAPTER IV}

\section{THE KINDS OF ORATORY}

Oratory may be symbolized by a warrior's eye, flashing from under a philosopher's brow. - HARE, Guesses at Truth.

Since the days of Aristotle thinkers have generally divided orations into three classes. To these the advent of Christianity and the apostolic propaganda have added a fourth, that of the pulpit.

\section{Forensic, or Legal, Oratory}

Webster's plea in the " Dartmouth College Case" is an example of this kind of oratory. It proposes as its end the obtaining and the protecting of personal, corporate, or civil rights. The Greeks and Romans brought this style of oratory to a high degree of perfection, introducing, however, much material which to-day would be ruled out in any court of law. Modern nations have also given forensics much attention, but with the growth of the body of law this type of oratory has decidedly declined. Forensic oratory is of two kinds, - addresses to judges and addresses to juries.

\section{Deliberative, or Political, Oratory}

An excellent example is Burke's Speech on Conciliation with the American Colonies. Any speech ad- 
dressed to a number of deliberators with the object of inducing them to decide for or against the question at issue is termed forensic. The type dates from remote antiquity, and literature has preserved to us many brilliant specimens.

To-day the deliberative orator has abundant opportunity for the display of his powers, not alone in the many assemblies where questions are mooted and decided, but before audiences gathered to consider important questions of varied sorts. Deliberative oratory deals with personal questions, only as they affect the interests of a body of individuals.

\section{Sacred, or Pulpit, Oratory}

Beecher's sermon on Sowing and Reaping is a well-known example. The importance of pulpit oratory is greater than that of any other type, alike because of the number of those who are influenced by its power, and from the nature of the issues involved. Pulpit oratory is generally personal, the abstruse theological speculations of a century ago having given place to the more practical sermons of to-day.

\section{Demonstrative, or Occasional, Oratory}

This is the most widely inclusive of all types. It may propose for itself any one of a number of ends as will presently appear.

Forensic, deliberative, and pulpit orators seek to in- 
fluence the intellect and emotions so as to move the will. This is not necessarily the case in demonstrative oratory. It seeks to impress a truth rather than to impel to action; to please thought and feeling, rather than to arouse motive; to make just and fitting observations, rather than to convince the judgment. An examination of the several kinds of demonstrative orations will serve, better than definition, to make this difference apparent.

The most frequent type is the (a) Occasional, under which are included orations delivered upon special occasions, as (I) anniversary (as Chauncey M. Depew's oration on the One Hundredth Anniversary of the Inauguration of President George Washington); (2)dedicatory (as Abraham Lincoln's Gettysburg Speech); and (3) commemorative (as Daniel Webster's oration on the lives of John Adams and Thomas Jefferson).

(b) Eulogy and Invective, as kinds of demonstrative oratory, must be considered as but a single form. The terms are in themselves sufficiently definitive. When the speaker both eulogizes the admirable qualities, and denounces the faults, of a character, striving to present a just balance of criticism, the discourse is called an appreciation, meaning an estimate.

In his Modern American Oratory, R. C. Ringwalt observes that two methods of handling personal subjects are commonly adopted: "The first method, once much followed, is what may be called the biographical method. A life is treated chronologically. From the 
early years to the end the eulogist follows with minuteness the career of the subject, reserving only a brief space before the conclusion for observations and reflections." (Compare Edward Everett's eulogy of Lafayette.) The second method is the one employed by most speakers, because it is more likely to prove suggestive to the speaker and interesting to the audience. Instead of giving a chronological narrative, "an effort is made to single out and set forth clearly what the subject of the eulogy accomplished in his life; what he stood for; what influence he exerted; and what is likely to be his place in history." The advantages of this latter method are obvious.

(c) Popular Oratory may serve as a general term under which to group all remaining styles of demonstrative orations. Popular lectures, addresses before societies and schools on special occasions, school and college orations, and after-dinner oratory should be classified under this general head. There is here so much room for individual taste, and there are so many limitations arising from the nature of the occasion; that special comment would be valueless. The observations presented in Part II. will be found to bear more particularly upon Demonstrative and upon Pulpit Oratory. 


\section{CHAPTER V}

\section{ELOQUENCE}

List his discourse of war, and you shall hear A fearful battle rendered you in music.

- Shakespeare, Henry $V$. Act I. Scene I.

Sometimes the orator rises to the "vehement simplicity" of eloquence. Emerson said that eloquence is "a taking sovereign possession of the audience"; Lyman Beecher described it as "logic on fire"; and De Quincey wrote, "By eloquence we understand the outflow of powerful feelings upon occasions fitted to excite them." But this apotheosis of soul-communication can neither be taught nor exactly defined - we must approach it by exposition, precept, and example. Thus Daniel Webster has characterized it:-

"When public bodies are to be addressed on momentous occasions, when great interests are at stake, and strong passions excited, nothing is valuable in speech farther than as it is connected with high intellectual and moral endowments. Clearness, force, and earnestness are the qualities which produce conviction. True eloquence, indeed, does not consist in speech. It cannot be brought from far. Labor and learning may toil for it, but they will toil in vain. Words and phrases 
may be marshaled in every way, but they cannot compass it. It must exist in the man, in the subject, and in the occasion. Affected passion, intense expression, the pomp of declamation, all may aspire to it; they cannot reach it. It comes, if it comes at all, like the outbreaking of a fountain from the earth, or the bursting forth of volcanic fires, with spontaneous, original, native force. The graces taught in the schools, the costly ornaments and studied contrivances of speech, shock and disgust men, when their own lives, and the fate of their wives, their children, and their country, hang on the decision of the hour. Then words have lost their power, rhetoric is vain, and all elaborate oratory contemptible. Even genius itself then feels rebuked and subdued, as in the presence of higher qualities. Then patriotism is eloquent; then self-devotion is eloquent. The clear conception, outrunning the deductions of logic, the high purpose, the firm resolve, the dauntless spirit, speaking on the tongue, beaming from the eye, informing every feature, and urging the whole man onward, right onward to his object, - this, this is eloquence; or, rather, it is something greater and higher than all eloquence, - it is action, noble, sublime, godlike action."

Thus we see that a high and noble attitude of mind is inseparable from true eloquence, and therefore this rare excellence is found oftenest in one who feeds his nature upon lofty truth and expends his life in unselfish service. Eloquence is born of just such a sensitive 
spirit, powerfully wrought upon by an unusual thought, feeling, event, or occasion.

It is important to observe that eloquence is not purely subjective; it needs the responsive listener. No orator, how rare soever his gifts, can rise to eloquence unless he and his audience come to sympathize. Their thoughts and feelings must fuse. Not only must the orator win his hearers to his thought, feeling, and will, but he must be responsive to their influence as well. It is this mutual inspiration, at once so elusive and so essential, which creates that remarkable combination of art, gift, and environment that we call eloquence. Macaulay records of Pitt that "the lofty and spiritstirring eloquence which had made him supreme in the House of Commons, often fell dead in the House of Lords." Later we shall see that, though eloquence cannot be taught, the orator may do much to bring about the conditions, both in himself and in his audience, which make eloquence possible. 


\section{PART II}

\section{PREPARATION OF THE DISCOURSE}


Prepared on every side. - Motto of the IrISh EarL of Cavan.

In literary as in all other art, structure is all-important, felt, or painfully missed, everywhere - that architectural conception of work, which foresees the end in the beginning and never loses sight of it, and in every part is conscious of all the rest, till the last sentence does but, with undiminished vigor, unfold and justify the first - a condition of literary art, which . . . I shall call the necessity of mind in style. - Walter Pater. 


\section{PART II}

\section{PREPARATION OF THE DISCOURSE}

Only when the speaker understands the nature of public speech, is conversant with the literary forms in which it may be cast, and has determined upon the kind of speech or oratory he will attempt, - only then can he intelligently approach the work of specific preparation. The orator having thoroughly mastered these fundamental ideas, briefly outlined in the preceding chapters, the work of preparation is likely to proceed much more rapidly and effectively.

It should scarcely be necessary to dwell upon the importance of preparation, yet the prevalence of illconsidered addresses and the presumptuous reliance placed by many in the ability (?) to improvise, prove that too many speakers either prepare badly or prepare not at all.

Plutarch assures us that Demosthenes gave closest attention to preparation. From this some unthinking persons inferred that he was not a great orator. "Pytheas, in particular, told him that all his arguments smelled of the lamp. Demosthenes retorted sharply upon him: 'Yes, indeed, but your lamp and mine, my friend, are not conscious to the same labors.' To others 
he did not pretend to deny his previous application, but told them he neither wrote the whole of his orations, nor spoke without first committing part to writing." 1

Tytler says of this same great orator: "His voice was harsh and uncouth, his articulation indistinct, and his gestures awkward and constrained; but, sensible of his defects, he labored night and day in private exercises of elocution, till he completely subdued them; and then, confident of his powers, he broke forth at once, the most distinguished orator of his age."

The lives of orators abound with illustrations of this character. Surely no one who seriously hopes to attract and hold an audience will think of his hearers so contemptuously as to under-estimate the importance of preparation.

1 Life of Demosthenes, Plutarch. 


\section{CHAPTER VI}

\section{ORIGINALITY}

There are two kinds of artists in this world : those that work because the spirit is in them, and they cannot be silent if they would, and those that speak from a conscientious desire to make apparent to others the beauty that has awakened their own admiration. - Anna Katherine Green, The Sword of Damocles.

Samuel Johnson once said of Gray, the author of the Elegy, "He was dull in a new way, and that made many people think him great." 1 This savage criticism time has disallowed, but the critic has at least thrown a sidelight upon originality. The great mass of alleged original matter is merely old thought reset in new form, or a new combination of old materials. Originality is a relative term.

\section{The Test of Originality}

It is more important to know whether or not your own mind is creative than to determine that fact as to others. Here is a sure test:-

How does my mind act when it receives new truth?

Does it enjoy the truth, and then give it out again unaltered, in exactly or substantially the same words?

1 Life of Johnson, Boswell, p. 241. 
That is quotation, if credit is given to the author; otherwise it is literary theft.

Does my mind feel stimulated, upon receiving truth, to produce other thoughts, and yet utter the received truth without change? That is expansion.

Does my mind not only receive a stimulus from new truth, but also assimilate it, transform, clarify, and amplify it, so that in uttering that truth I utter it stamped with my own image and superscription? That is originality.

That is the test. It is as high as it is final. An original thought is a new birth, - the fruit of a union of truth from without and of thought from within. A fertile intellect, open to truth, sensitive to take it in, and ready both to act upon it and to be acted upon by it, is that rarest of all intellectual facts, an original mind.

In Vawder's Understudy James Knapp Reeve makes one of his characters remark that an original idea comes to a mind about once in a lifetime, and when it does come it should be entertained. This is too high an estimate for most minds. Ingenuity, novelty, cleverness, they may have, but originality never. "This is not a reason for disparagement. (They are in good company, and have plenty of it. Even an original mind cannot always demonstrate its fertility, and many keen, cultured intellects never rise to originality in the high sense just set forth. Furthermore, some truths never do any more than stimulate even a fertile mind, because they are complete in themselves. To change would be 
to destroy them. Their function is not to fructify but to stimulate the mind into which they enter. And a large part of our mental output is the result of such stimulating suggestion. This is not originality, in the strictest sense, though such it is according to the popular use of the term. It is the only creative spirit which many able orators possess, and it is second rate only to pure originality itself. Popularly, we call that man original who stands on his own feet, uses the thoughts of others only to stimulate and supplement his own, and who does his best to color borrowed thought with the hue of his own personality. Such a man, if he be not a creator, is at least a thinker, and a thinker need never be a literary thief.

A suggestive thought entering a well-furnished mind is sure to call up images, reflections, and trains of interesting ideas which will prove to be most valuable oratorical material. Such stimuli must by no means be under-estimated. If genuine originality is as rare as Mr. Reeve suggests, the entrance of any thought that will set the mind to working should be welcome indeed.

\section{The Sources of Originality}

Rare as genuine originality is, the number of those who attain thereto would be largely increased did orators make it the object of serious effort.

A study of the mental habits of original thinkers and speakers reveals several suggestive facts.

(a) Original minds are observers of nature.-The 
same perennial source-spring is open to all. Upon every hand are the facts of inanimate and animate nature which spoke so powerfully to others. Human beings are much the same to-day as when their characteristic traits proved so suggestive to Attic and to Roman orators. It needs but an alert, receptive mind to take these things and transform them into material for oratory. Ruskin took a common rock-crystal and saw hidden within its stolid heart lessons which have not yet ceased to move men's lives. Beecher stood for hours before the window of a jewelry store thinking out analogies between jewels and the souls of men. Gough saw in a single drop of water enough truth wherewith to quench the thirst of five thousand souls. Thoreau sat so still in the shadowy woods that birds and insects came and opened up their secret lives to his eye. Emerson observed the soul of a man so long that at length he could say, "I cannot hear what you say, for seeing what you are." Preyer for three years studied the life of his babe and so became an authority upon the child mind. Observation! Most men are blind. There are a thousand times as many hidden truths and undiscovered facts about us to-day as have made discoverers famous, - facts waiting for some one to "pluck out the heart of their mystery." But so long as men go about the search with eyes that see not, so long will these hidden pearls lie in their shells. Not an orator but who could more effectively point and feather his shafts were he to search nature rather than libraries. Too few can see "sermons in stones" and 
"books in the running brooks," because they are so used to seeing merely sermons in books and only stones in running brooks. Sir Philip Sidney had a saying, "Look in thy heart and write;" Massillon explained his astute knowledge of the human heart by saying, "I learned it by studying myself ;" Byron says of John Locke that "all his knowledge of the human understanding was derived from studying his own mind." Since multiform nature is all about us, originality ought not to be so rare.

(b) Original minds have learned to think consecutively. - This is an age of second-hand thinking. We all ask for our milk malted, our meats peptonized, and our books digested. Reviews, condensations, and reference books are quite as typical of the intellectual life of the period as are labor-saving devices characteristic of the material world. Short cuts are the mania of the age. One marked result of all this is its effect upon the mental powers. Men are losing both desire and ability to think consecutively along other than business lines. True, education is in part meeting this lack; but only in part, for education cannot cope with the hop-skipand-jump mental habits fixed by the fragmentary articles which the average man skims over in his daily reading. A book is generally voted dry-as-dust which requires consecutive thought.

Dr. Nicholas Murray Butler proposes five tests of education, in the broadest sense of the term, and among them he places reflection. Here they are :- 
I. Correctness and precision in the use of the mother tongue.

2. Those refined and gentle manners which are the expression of fixed habits of thought and of action.

3. The power and habit of reflection.

4. The power of intellectual growth.

5. Efficiency, the power to do.

But if the lack of consecutive thinking is such a general failing, all the greater are the rewards offered to the public speaker who to his powers of observation is willing to add the ability to reflect, and to think systematically. Originality waits for him to crown his desire with gift.

(c) Original minds cherish the companionship of great thoughts. - How much might here be said! Three sentences must suffice. He who would produce original ideas must fertilize his mind by contact with the epochmaking thoughts of all ages. These he will find preserved to him in a few great books, and animating the minds of living men and women who are worth knowing. If there is anything in a mind, such companionship will call it forth.

(d) Original minds dare to be themselves. ${ }^{1}$ - Dare! The word is not ill-chosen. The penalty for failure is as severe as the meed of success is great. "Insist on yourself - never imitate," said Emerson, - himself a most individual man. Yet originality has cost many a man martyrdom; countless others, loss of popularity; 
and all, some more or less serious temporary sacrifice. "Nothing succeeds like success." Successful men may be canonized, unsuccessful fellows are cannonaded.

The quality of an earnest mind may be tested in this: Am I willing to stand on my own feet now - and so strengthen myself for future walking, even by my very stumbling efforts - rather than to use crutches for the sake of more rapid progress in the beginning? The young speaker who dares to be himself, casting artificiality to the winds, will begin by making less brilliant speeches than his companions who copy and crib, but his power and invention will increase, and he will end far in advance of his less original rivals. Far better the occasional blunders of an original speaker than the inane and icy correctness of a lifeless imitator.

Doubtless natural gifts count for much, but let the young orator patiently observe nature, let him practise consecutive thinking, let him cherish the companionship of great thoughts, let him dare to be himself, and his mind will come to be as original as its native capacity will allow. 


\section{CHAPTER VII}

\section{THE SUBJECT}

Suit your topics to your strength, And ponder well your subject, and its length; Nor lift your load, before you're quite aware What weight your shoulders will, or will not, bear. - Byron, Hints from Horace.

The speaker is not always at liberty to select his theme. Moreover, circumstances frequently place such limitations upon its choice, if they do not positively decide what topic would be appropriate, that the field of selection is immediately narrowed - in many instances a not undesirable condition of affairs.

A primary consideration in selecting a subject is -

\section{What is Due the Occasion?}

Every address should be the best possible under the circumstances, and therefore you must accurately measure those circumstances. Even though you be neither a prophet nor the son of a prophet, there are some things you must try to forecast; for instance: Who will be there? What subjects should interest them? What will be the intelligence of the average auditor? What subjects are timely? What other 
speakers or exercises are on the program? What is my position on the program? What will be the spirit of the audience? What is the object of the meeting? Exactly how many minutes are assigned to me?

So important are these questions that upon their answers depends the fitness of the discourse to the occasion; in other words, its success or its failure. "He is a happy speaker"; "He always hits the nail on the head"; "He was like a square peg in a round hole"; "He floundered like a fish out of water" it is for the speaker to choose which of the foregoing figures shall aptly characterize his platform effort. ${ }^{1}$

\section{What is Due the Subject?}

Some themes may be treated satisfactorily in a few minutes, while others require hours. It is manifestly due a subject that you reject it if the circumstances forbid its adequate treatment. There is something personal in a subject, something which seems to resent an unworthy handling. And no speaker has a right to attempt a theme unless there is some assurance of his being able, under the circumstances, to discuss it adequately. If the subject is too broad, it is often possible to modify or adapt it. Indeed, most young speakers make the mistake of selecting too broad a subject; for, strange as it may seem to the uninitiated, the narrower the subject, the easier the treatment. It would be quite 
impossible adequately to discuss "The Suffrage Question" within such limits of time as are ordinarily set for an oration; whereas "A Limited Suffrage for the Negro," or "Woman's Ballot in National Elections," could be handled within a reasonable period of time. But even with such specific subjects as the foregoing, care must be taken to make the treatment general, or particular, according to the occasion, as well as to state clearly and forcefully the dominant proposition of the discourse. Though hackneyed subjects should be avoided, new light on old themes is always welcome, and some questions are of perennial interest. Above all, the subject must have unity; that is, it must not be a medley of loosely connected thoughts. ${ }^{1}$

\section{What is Due the Speaker?}

The author does not share the opinion of some, that an address is altogether for the audience. There are also, as we have seen, some things due the subject, and just as certainly some things are due the speaker.

No one has a moral right to make himself ridiculous upon a serious occasion. The speaker may fittingly repeat the Psalmist's prayer: "Keep back thy servant also from presumptuous sins," for offenses of this type before an audience are distressingly common. The man who does not know his own limitations will scarcely be able to profit his hearers. It is, therefore, due the 
speaker that he should not select a theme with which he is unacquainted, or which is beyond his abilities; that he should discard a subject too heavy or too trivial. to be handled satisfactorily in the time assigned, either for preparation or for delivery; and that, in fine, he should consider carefully the three phases of obligation set forth in this section before selecting or accepting a subject. $^{1}$

1 The two methods which may be employed in selecting a subject are discussed in section $\mathbf{I}$ of Chapter IX. 


\title{
CHAPTER VIII
}

\author{
THE TITLE
}

Call things by their names. - Robert HaLL.

There is a distinction to be made between the subject of a discourse and its title. The former is the substance, the latter the name.

\section{An Attractive Title}

Several important ends may be gained by the choice of an attractive title: it is likely to create a desire to hear the address, and so bring hearers to the assembly; it frequently assures interested attention at the beginning of the address - it rests with the speaker to maintain and augment that interest; it often reacts upon the speaker himself, imparting a keen desire to speak upon the theme as stated, and this zest for the occasion is half the victory.

Though it may be doubted whether the search for an attractive title should lead a speaker far from his real subject, here, as always, the "golden middle-way" (to use a German idiom) is likely to prove the wise course. Good taste, upon the one hand, will reject sensational and high-sounding titles; a keen mind, upon the other, will be quick to discard a dull and uninteresting form of 
statement and adopt a graceful phrase, a subtle allusion, a suggestive epithet, or a striking figure, instead.

It is easy to choose between such titles as: "Evils in Modern Charity Administration" and "Modern Charity - Wise and Otherwise" ; or between "Heredity the Subject of Choice" and "Choosing an Ancestor."

\section{A Truthful Title}

It is of no small importance that a title should not arouse anticipations which the discourse is likely to disappoint. It is fatal to a speaker's success to have the auditors find that they were cajoled by an attractive title into expecting a feast when only a fast was prepared. It is quite as disappointing to select a minor and obscure phase of the subject and announce it as though it were the dominant, working idea.

\section{A Descriptive Title}

This is insisted upon by some authorities, but in reality the choice in this respect depends upon the nature of the discourse. Titles of addresses designed to lead earnest minds along highways of thought upon which they have already entered, should doubtless be sufficiently descriptive to permit the prospective hearer to forecast the theme and determine as to its probable interest to him. The neglect of this simple act of justice naturally exasperates disappointed auditors. A wellknown speaker tells of an orator who announced a 
lecture upon "The Wine of the Scriptures." When the people assembled they found that in one respect only was the lecturer full of his subject.

A title which reveals its aptness only after the discourse has been heard, is certainly permissible, and even greatly to be commended, when indifferent auditors need to be allured and a zest of pleasant anticipation supplied to such as are already interested in either the speaker or the occasion. Let it be repeated, the object in view must decide.

From the announcement of such titles as "America, the Apostle of Peace," "Paternalism," "The Martyr in History," “Inspired Men," the prospective hearer could forecast the general tone of the discourse. But who could guess that "The Light That Failed" was not to be a discussion of Kipling's story, but of the failure of Reason as a guide during the French Revolution? No more would "An Unofficial Governor" indicate a treatment of the Citizens' Committee, nor "An Eye for an Eye" presage a discussion of capital punishment. Yet, as observed above, both classes of titles have their places, and the display of ingenuity and aptness is often desirable. 


\section{CHAPTER IX}

\section{THE MATERIALS}

General principles must be had from books, which, however, must be brought to the test of real life. - SAMUeL Johnson.

The learned reflect on what before they knew.

- POPE, Essay on Criticism.

We have seen the importance of choosing the subject for a discourse, and the conditions which should influence that selection have been pointed out. We must again touch upon this subject in considering the materials for the discourse.

\section{The Relation the Materials bear to the Subject}

Subject and materials influence each the other. This arises from the fact that there are two distinct ways in which a subject may be chosen, - by arbitrary choice, or by development from thought and reading.

(a) Arbitrary choice means the selection of a subject from reasons of its fitness. It involves a more or less painstaking examination of a number of available themes with a view to the wisest choice. Many speakers do not hesitate to say that this is the most difficult part of the labor of preparation. Choice is rarely as simple a matter as it seems, and is often most perplexing. 
To choose one subject from among a number involves so many important considerations that no speaker ever fails to appreciate the tone of satisfaction in the voice of him who triumphantly announces: "I have a subject!"

Do give me a subject! How often the weary teacher hears that cry. Then a list of themes is suggested, gone over, considered, and, in most instances, rejected, because the teacher can know but imperfectly what is in the pupil's mind. To suggest a subject in this way is like trying to discover the street on which a lost child lives, by naming over a number of streets until one strikes the little one's ear as sounding familiar.

(b) Choice by development is a very different process. It does not ask, What shall I say? It turns the mind in upon itself and asks, What do I think? Thus, the subject may be said to choose itself, for in the process of thought or of reading one theme rises into prominence and becomes a living germ, soon to grow into the discourse. He who has not learned to reflect is not really acquainted with his own thoughts; hence, his thoughts are not productive. Habits of reading and reflection will supply the speaker's mind with an abundance of subjects of which he already knows something from the very reading and reflection which gave birth to his theme. This is not a paradox, but sober truth.

It must be already apparent that the choice of a subject by development savors more of collection than of conscious selection. The subject "pops into the mind" - arises spontaneously. In the mind of the trained 
thinker it concentrates, by a process which we have seen to be induction, ${ }^{1}$ the facts and truths of which he has been reading or thinking. This is most often a gradual process. The scattered ideas may be but vaguely connected at first, but more and more they concentrate and take on a single form, until at length one strong idea seems to grasp the soul of the orator with irresistible force, and to cry aloud, "Arise, I am your theme! Henceforth, until you transmute me by the archemy of your inward fire into vital speech, you shall know no rest!" Happy, then, is that orator; for he has found a subject that grips him.

Of course, experienced speakers use both methods of selection. Even a reading and reflective man is sometimes compelled to hunt for a theme from Dan to Beersheba, and then the task of gathering materials becomes a serious one. But even in such a case there is a sense in which the selection comes by development, because no careful speaker settles upon a theme which does not represent at least some matured thought.

\section{Subordination of Material to the Object}

Oratory has not only a subject, but also an object. Even though that object may not be openly revealed to the audience, still, like the theme in a symphony, it will appear and reappear, with each recurrence gaining volume and momentum, until at length its swelling note of power takes possession of the whole composition, and rises to a climax of emotion and conviction. 
Now this central, dominating motive must not for a moment lose its influence in all the stages of the inception, birth, and life of an address; but especially must it control while the materials are being gathered. One word of caution, however. Whether the material be that of thought or of form, whether it fly sparkling hot from the beaten anvil of your own brain, or come scintillating from the treasure house of a wealthy past, resolutely discard it if it does not belong necessarily to your subject, if it does not in some real way help to accomplish your object. It may cost you a twinge, but it will save your audience a pang. Such a loss is a great gain. Effective speech owes quite as much to what the orator rejects as to what he selects. You must not say everything upon a subject - not even all of the important things - even if you could. Life is too short.

\section{Organizing Material around the Subject}

While considering the subject of originality the im. portance of observation, reading, and reflection was pointed out. These are the three mental operations employed in gathering materials. In direct proportion as these become habits of mind will the acquisition of something to say become a pleasure and not a punishment.

Perhaps enough about habits of observation and reflection has been said in Chapter VI. One word more must be set down regarding reading. If we except the gathering of facts directly necessary, such 
reading as is done for the preparation of a discourse had better be of the inspirational type. That is, of a sort which, by the vigor of its thought, will strike fire in the spirit, and make you feel and think. Glowing under the mighty warmth, you will rush to your notebook (always at hand) and set down the suggestions which come trooping to your help.

Nothing can be more hurtful than to follow the common advice: Wait until you have gathered all your material and then organize it. No! Be organizing it all the while you are gathering it. First, formulate your subject - which has already been compared to a germ, containing within itself the full-blown plant, the discourse - in a single, lucid, compact, vigorous sentence, so that the subject may be the whole discourse condensed, and the discourse only the subject expanded. Bear its impress upon your soul, sleeping or waking, and let it grow. The results of your reflection, observation, and reading will be its food, and from the plenitude of materials with which your faculties will come full-handed, you will incorporate into this growing thing of life such essential fiber and beauty as will give it at once vigor and charm.

\section{The Management of Notes}

This will grow easy with experience. The first thing many speakers do is to devote a separate slip of paper, or page of notebook, to each major section of the discourse, as, Introduction, etc. Upon each is set down 
such ideas as seem naturally to belong to that section. Even then it will be necessary later to classify facts and rearrange ideas still more accurately, and this can readily be done by lettering or numbering such as you may have set down out of the desired order, or even upon the wrong sheet. Thus gradually the discourse will assume coherence, and without coherence no discourse can cleave to the soul. Thus, too, will the material grow up about the subject, and not about the title. It is true, sometimes the title is the subject, but this is so rarely the case as to justify the iteration of this important maxim: Keep your subject - the clear, concentrated expression of the whole truth of your discourse-always as a thought-unit before you. 


\section{CHAPTER $\mathrm{X}$}

\section{THE WRITING}

Write till your ink be dry; and with your tears moist it again.

- Shakespeare, Two Gentlemen of Verona.

No general rule can be laid down as to whether men should or should not write their discourses. The question is involved and must find its issue in practice. Volumes have been penned for and against written preparation, but, after all, the obligations of the speaker to the occasion, to the subject, and to himself, must be the determining factors.

Those who adopt the extemporaneous method generally prepare a brief, or outline, of the discourse, to which they may refer during delivery. The preparation of the brief proceeds along the lines suggested in the preceding chapter. The only directions which can here be given are that the brief should be logical and cumulative in its order, suggestive or "catch" words and sentences should be used, and it should be so clearly set on paper that its divisions will quickly strike the eye. Type-written material is more difficult to read than good manuscript, because the individualities of 
personal writing are not there to catch the eye and assist the memory. ${ }^{1}$

But it is in the actual writing that the personality and worth of the materials must become apparent. A mass of materials is no more a discourse than a pile of stone and lumber is a cathedral. To select, adapt, fit, unify, and beautify materials is the duty alike of the builder and of the orator. It was Pascal who wrote: "In playing tennis both use the same ball, but one places it better than the other. It might be objected that I use current words; as if the same thoughts did not form a different body of discourse by a different arrangement." Here, then, the orator's personality becomes the prime factor. His breadth of knowledgeof rhetoric, logic, human nature, and, indeed, of everything - comes most powerfully into play.

Regarding this actual writing of a discourse some suggestions may be given. The work of organizing the material having so far advanced that a logical outline has been formed in the mind, and a considerable body of notes accumulated, you should commit to paper

\section{The Working Outline}

Young speakers may find this task both arduous and disappointing - faults look so glaring when spread, black on white, before the eye. But for this very

1 Excellent discussions of the preparation and use of the brief will be found in Argumentation, Baker; and in Briefs for Debate, Brookings and Ringwalt. 
reason let the beginner take heart of courage and persevere. The glow of final writing must not be depended upon to supply defects of thought structure, any more than an architect may expect paint to remedy the weakness of a truss. This outline will reveal faults in proportion, weak links in the chain of reasoning, and - those greatest foes to forceful oratory - cloudy ideas.

Study these wise words of Professor Genung:

"But in truth this learning to plan is the practical way of training the mind into the habit of seeking order; and when the habit is fully formed, the act of planning, which at the beginning seemed arbitrary and mechanical, will resolve itself into the discovery of the natural movement of a thought. Planning must begin awkwardly. It is well for the writer if he sticks to the work until he is at home in it. $\mathrm{He}$ may have to work through a period more or less wooden; he may be tempted to odd or fanciful structures of thought; he may at some stage be bitten with the craving for mere ingenuity, - strange if he is not. But gradually he will reach a point where with every subject the vision of a plan will rise before him; he will come to see it, not vaguely, but as an articulated whole; and by and by he can surrender himself to the natural working of his mind, because the artistic, the finely logical, has become nature." 1

As to the manner of tabulating thoughts in the out-

1 Working Principles of Rhetoric, pp. 432-433. 
line, the scheme of numerals, letters, and underscoring followed in this treatise may prove suggestive.

So much space has been given to the working outline because of its preëminent place in the preparation of all kinds of public address. Now, without entering the field of Rhetoric to discuss the laws of composition, some thoughts may be with profit suggested regarding the next step in composing the discourse.

\section{The First Writing}

When once pen is set to paper for the full writing of an address, the work of composition should be pressed with fervor, concentration, and rapidity. The audience should always be in the mind's eye, the subject clearly before you, and the object powerfully dominating every sentence, so that each succeeding passage may become increasingly an instrument to transfer your state of mind and feeling to your auditors. This is not to say that the object of the discourse must always stand out consciously. Sometimes it will simply pervade the mind while you write, a fire in your bones kindling thought and word, a power which drives you forward to expression, with irresistible energy. This motive must first possess you before it can possess your hearers. You must yield yourself to its sweep and swell as a strong swimmer yields to the rising of the waves; and yet, as does he, you must all the while deftly direct your own course. 
This surrender to the dominating spirit of the theme it is which will enable you to write in a glow, or at least, to write yourself into a glow. In such a mood do not strive too ardently for exactness. For the time, sacrifice all to fire and movement-reserve correction for the coldly critical hour of

\section{The Final Revision}

This must intervene between writing and delivery if you value correctness. But it is a duty that must be approached with a quite judicial impartiality, the mind alert to discover errors and remorseless to cut out passages, however attractive, which are not absolutely necessary. Before attempting this revision it would be well for young speakers to re-read some digest of rules, such as appears on pages I00-108 of this volume. But steer clear of the error of polishing the edge off of your discourse. "Some people," says Cowper, "are more nice than wise." Better that your style should limp than that your discourse should lack vitality - but good style and vitality are one. Do not revise the snap out of your discourse. Make your words hit the mind with the impact of a bullet. Rules should be your servants, not your masters. 


\section{CHAPTER XI}

\section{THE GRAND DIVISIONS OF THE DISCOURSE}

We may our ends by our beginnings know.

- Denham, Of Prudence.

All's well that ends well. - ShaKespeare.

From the days of the Greek rhetoricians and orators, certain grand divisions have been recognized in the structure of a public discourse. The most satisfactory partition seems to be a fourfold one: $(a)$ introduction, (b) statement, (c) discussion, $(d)$ peroration. Sometimes the second is merged with the third division.

This general arrangement will naturally be in the mind while the working outline is being formed, so that a harmonious progress of thought may be preserved throughout.

\section{The Introduction 1}

Not every address requires an introduction. It is always foolish "to preface something in particular by at least a paragraph of nothing in particular, bearing to the real matter in hand a relation not more inher-

${ }^{1}$ See Modern American Oratory, Ringwalt, pp. 55-60. 
ently intimate than that of the tuning of violins to a symphony." 1

When, however, the introduction is properly used, it is designed to put the audience in possession of such facts or ideas as will secure to the speaker sympathetic attention and confidence. In rare cases, the orator may be compelled even to placate hostility. ${ }^{2}$ Hence the opening words of a discourse should be brief, manly, modest, moderate, frank, and tactful. Many an unhappy orator has been compelled to bring into play all his resources of power in order to win back from his hearers the sympathy and confidence which he forfeited while speaking the introductory sentences he was fortunate in regaining so much as a part of what he had lost. A careful study of public assemblies will yield golden rewards to him who would learn the way of approach to an audience. ${ }^{3}$ )

The appended introductions may well be studied as revealing the practice of great orators.

Daniel Webster's deliberative oration, “ In Reply to Hayne," begins with this beautiful allusion :

"When the mariner has been tossed for many days in thick weather and on an unknown sea, he naturally avails himself of the first pause in the storm, the earliest glance of the sun, to take his latitude and ascertain how far the elements have driven him from his true course."

The orator then applies the illustration to the debate upon which he has entered.

${ }^{1}$ English Composition, Wendell, p. 167. ${ }^{2}$ See p. 151. ${ }^{3}$ See p. 149. 
Wendell Phillips thus begins his popular lecture on "Toussaint l'Ouverture" :-

"I have been requested to offer you a sketch of one of the most remarkable men of the last generation, the great Toussaint l'Ouverture. My sketch is at once a biography and an argument, - a biography of a negro statesman and soldier, and an argument in behalf of the race from which he sprang."

Henry W. Grady began his great after-dinner oration on "The New South" by making a quotation:-

" "There was a South of slavery and secession - that South is dead. There is a South of union and freedom - that South, thank God, is living, breathing, growing every hour.' These words, delivered from the immortal lips of Benjamin H. Hill, at Tammany Hall, in I866, true then, and truer now, I shall make my text tonight."

Judge Jeremiah S. Black prefaced his forensic oration on "The Right to Trial by Jury" with these words :"May it please your Honors: I am not afraid that you will underrate the importance of this case. It concerns the rights of the whole people. Such questions have generally been settled by arms. But since the beginning of the world no battle has ever been lost or won upon which the liberties of a nation were so distinctly staked as they are upon the results of this argument. The pen that writes the judgment of the court will be mightier for good or for evil than any sword that ever was wielded by mortal arm." 


\section{The Statement}

The office of this division is to set forth in clear, concise, exact words the end proposed by the discourse, the proposition to be proved, the precise nature of the subject, or the speaker's attitude toward his theme, - in a word, in the statement the orator declares his platform and defines his position.

Sometimes it may seem desirable to reserve the statement for later announcement, or even to omit it entirely.

Frequently the introduction and statement are deftly interwoven, as in some of the instances quoted under "The Introduction," and occasionally an orator will use no other introduction than a simple statement, as did Webster in the Dartmouth College Case :-

"The general question is, whether the acts of the legislature of New Hampshire of the twenty-seventh of June and of the eighteenth and twenty-sixth of December, I8I6, are valid and binding on the plaintiffs without their acceptance or assent."

The following, from Ruskin's lecture on "Turner and his Works," is both an introduction and a statement :-

"My object this evening is not so much to give you any account of the works or the genius of the great painter whom we have so lately lost (which it would require rather a year than an hour to do), as to give you some idea of the position which his works hold with respect to the landscape art of other periods, and of the general condition and prospects of the landscape art of 
the present day. I will not lose time in prefatory remarks, as I have little enough at any rate, but will enter abruptly on my subject."

Such statements place the hearer at once in the clear, and favorably dispose him toward the frankness of the orator.

Sometimes speakers include in the introduction-statement an announcement of the main heads or propositions of the discourse, as the following from Prof. Huxley:-

"The subject to which I have to beg your attention during the ensuing hour is 'The Relation of Physiological Science to Other Branches of Knowledge.'

[Here follows a paragraph of personal explanation.] "Regarding Physiological Science, then, in its widest sense, as the equivalent of Biology, the Science of Individual Life, we have to consider in succession :-

“I. Its position and scope as a branch of knowledge.

“2. Its value as a means of discipline.

"3. Its worth as practical information.

"4. At what period it may best be made a branch of education." 1

But this is too formal a method for brief platform efforts, and valuable only when it is highly necessary to keep clearly before the audience both the main proposition and the body of argument by which it is to be sustained. The same end is usually better attained by a rapid summary in the beginning of the peroration.

${ }^{1}$ Huxley, V. p. 72, quoted by J. M. Hart, Handbook of English Composition. 


\section{The Discussion}

The discussion constitutes the body of the discourse, hence to it the other parts must be joined in such a way as to make smooth connections, and to preserve its preëminence. It is the sine qua non of all oratory. And yet little valuable advice can be given as to the conduct of the discussion,- - beyond such suggestions concerning literary and logical forms as appear elsewhere, - for the reason that constantly varying conditions of theme, motive, orator, and audience give birth to ever changing ideas in the discussion. The most valuable precepts are those which urge the speaker to formulate his thoughts and to couch his language according to the laws of sound reason ${ }^{1}$ and of good English. ${ }^{2}$ As to the former, remember what Butler said of Hudibras :-

"He knew what's what, and that's as high As metaphysic wit can fly."

As to the latter, follow the advice of Francis Bacon: "Come home to men's business and bosoms."

\section{The Peroration}

The conclusion of the discourse, brief as it should be, must be regarded as furnishing an opportunity for the most effective oratory. Since final impressions remain long upon the mind, "the discourse should end with words that deserve distinction." 3

${ }^{1}$ See p. $10 . \quad{ }^{2}$ See p. 100.

${ }^{3}$ English Composition, Wendell, p. 103. 
The peroration may consist of: a summary of the entire theme, a recapitulation of the main points advanced, an enforcement of the central truth, a call to action, an appeal to the emotions, or a combination of several or all of these methods. Elevated style aná an impassioned appeal usually characterize the peroration in demonstrative oratory.

Though the concluding sentences should be in themselves a climax to the whole discourse, yet it is rarely wise to end the effort the very instant when emotion has reached the highest pitch. Rather should there be a moment of gentle subsidence from the lofty flight of impassioned utterance, so as to guard against a revulsion of feeling upon the part of the audience.

The study of good models will amply reward all who would cultivate the power of ending a discourse effectively.

Wendell Phillips concludes his speech on "A Metropolitan Police," with these words :

"Agitate, and we shall yet see the laws of Massachusetts rule even in Boston."

Edward Everett ends his oration on "Temperance" by generalizing this principle of action:-

"Let us, sir, mingle discretion with our zeal; and the greater will be our success in this pure and noble enterprise."

The same great orator employs this metaphor as the peroration for his oration on "The Importance of Scientific Knowledge" :- 
"When an acorn falls upon an unfavorable spot, and decays there, we know the extent of the loss - it is that of a tree like the one from which it fell; but when the mind of a rational being, for want of culture, is lost to the great ends for which it was created, it is a loss which no man can measure, either for time or for eternity."

A fine example of impassioned peroration is found in the closing words of Ruskin's lecture on "The Deteriorative Power of Conventional Art over Nations."

"Make, then, your choice boldly and consciously, for one way or other it must be made. On the dark and dangerous side are set the pride which delights in selfcontemplation + the indolence which rests in unquestioned forms + the ignorance that despises what is fairest among dod's creatures, and the dullness that denies what is marvelous in his working; there is a life of monotony for your own souls, and of misguiding for those of others. And, on the other side, is open to your choice the life of the crowned spirit, moving as a light in creation - discovering always - illuminating always, gaining every hour in strength, yet bowed down every hour into deeper humility; sure of being right in its aim, sure of being irresistible in its progress; happy in what it has securely done-happier in what, day by day, it may as securely hope; happiest at the close of life, when the right hand begins to forget its cunning, to remember, that there was never a touch of the chisel or the pencil it wielded, but has 
added to the knowledge and quickened the happiness of mankind."

\section{The Entire Discourse}

It is quite possible so perfectly to develop these grand divisions of the discourse singly, as to sacrifice the effect of the whole to the perfection of the parts a fatal blunder indeed. In their true relation each exists for the other, and all exist for the sake of the whole. ${ }^{1}$

The ideal discourse may be compared to an oval. The introductory statement presents the subject as a thought unit. Throughout the discussion this subject is expanded and amplified. In the peroration it is again compacted, and at length penetrates the minds of the auditors as a single impressiop.

${ }^{1}$ See p. 108, Section VI. 


\section{CHAPTER XII}

\section{HOW TO ACQUIRE AN ORATORICAL VOCABULARY}

The knowledge of words is the gate of scholarship. - WiLson.

It is not commonly remembered that the term "vocabulary" has a special as well as a general meaning. All vocabularies are indeed based upon the common every-day words of the language, but each special vocabulary possesses a number of words of peculiar value for its own objects. Such words may be used in other vocabularies also, but the fact that they are suited to a unique order of expression marks them as of special value to a particular craft or calling.

In this respect the orator differs not at all from the poet, the novelist, the scientist, the traveler. He must add to his every-day stock, words of value for the public presentation of thought. A study of the discourses of effective orators discloses the fact that they have a fondness for words signifying power, largeness, speed, action, color, light, and all their opposites. They frequently employ words expressive of the various emotions. Descriptive words, adjectives used in fresh relations with nouns, and apt epithets, are freely employed. Indeed, the nature of public speech permits the use of mildly exaggerated words which, by the time 
they have reached the hearer's judgment, will leave only a just impression.

No one truly possesses a word until he knows its exact meaning, understands its relation to other words, and has it ready for use.

How can this be accomplished?

Determination and method will do wonders. The student must apply the former - the author can only suggest the latter.

\section{Gather Words from the Written and Spoken Dis-}

\section{courses of Effective Speakers}

In studying oratorical words as well as oratorical forms, the true way is to note the usages of great orators. The careful analysis of one great oration will do you more good than chapters of theory.

In studying words, remember that the notebook habit is altogether admirable. The author has in mind a speaker of superior attainments who acquired his vocabulary by noting all new words he heard or read. These he mastered and put into use. Soon his vocabulary became large, varied, and accurate. Use a new word accurately five times and it is yours.

\section{Form the Dictionary Habit}

Do not be content with your general knowledge of a word. Press your, inquiry until you have grasped its individual shade of meaning and usage. Fluency 
may become despicable, but accuracy never. No dictionary is perfect, still, any standard lexicon contains the crystallized usage of intellectual giants. No one who would discourse effectively dare despise its definitions and discriminations.

\section{Seek Diligently for just the Right Word}

This involves a careful study of synonyms and antonyms. Fortunately, there is no lack of excellent manuals for the guidance of students and for ready reference.

"I am growing so peevish about my writing," says Flaubert. "I am like a man whose ear is true, but who plays falsely on the violin: his fingers refuse to reproduce precisely those sounds of which he has the inward sense. Then the tears come rolling down from the poor scraper's eyes and the bow falls from his hand." 1

The same brilliant Frenchman sent this sound advice to Guy de Maupassant: "Whatever may be the thing which one wishes to say, there is but one word for expressing it, only one verb to animate it, only one adjective to qualify it. It is essential to search for this word, for this verb, for this adjective, until they are discovered, and to be satisfied with nothing else."

Walter Savage Landor once wrote, "I hate false words, and seek with care, difficulty, and moroseness those that fit the thing." So did Sentimental Tommy, 
as related by James M. Barrie in his admirable novel bearing his hero's name as a title. No wonder T. Sandys became an author and a lion!

Tommy, with another lad, is writing an essay on "A Day in Church," in competition for a university scholarship. He gets on finely until he pauses for lack of a word. For nearly an hour he searches for this elusive thing, until suddenly he is told that the allotted time is up, and he has lost! Barrie may tell the rest :-

Essay! It was no more an essay than a twig is a tree, for the gowk had stuck in the middle of his second page. Yes, stuck is the right expression, as his chagrined teacher had to admit when the boy was cross-examined. He had not been "up to some of his tricks" ; he had stuck, and his explanations, as you will admit, merely emphasized his incapacity.

He had brought himself to public scorn for lack of a word. What word? they asked testily; but even now he could not tell. He had wanted a Scotch word that would signify how many people were in church, and it was on the tip of his tongue, but would come no farther. Puckle was nearly the word, but it did not mean so many people as he meant. The hour had gone by just like winking; he had forgotten all about time while searching his mind for the word.

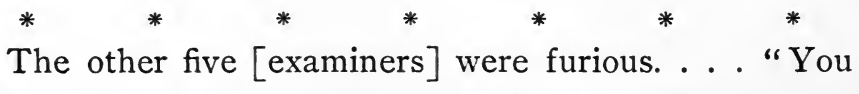
little tattie doolie," Cathro roared, "were there not a 
dozen words to wile from if you had an ill-will to puckle? What ailed you at manzy, or -"

"I thought of manzy," replied Tommy, wofully, for he was ashamed of himself, "but - but a manzy's a swarm. It would mean that the folk in the kirk were buzzing thegither like bees, instead of sitting still."

"Even if it does mean that," said Mr. Duthie, with impatience, "what was the need of being so particular? Surely the art of essay-writing consists in using the first word that comes and hurrying on."

"That's how I did," said the proud McLauchlan [Tommy's successful competitor]. . . .

"I see," interposed Mr. Gloag, "that McLauchlan speaks of there being a mask of people in the church. Mask is a fine Scotch word."

"I thought of mask," whimpered Tommy, "but that would mean the kirk was crammed, and I just meant it to be middling full."

"Flow would have done," suggested Mr. Lorrimer.

"Flow's but a handful," said Tommy.

"Curran, then, you jackanapes!"

"Curran's no enough."

Mr. Lorrimer flung up his hands in despair.

"I wanted something between curran and mask," said Tommy, doggedly, yet almost at the crying.

Mr. Ogilvy, who had been hiding his admiration with difficulty, spread a net for him. "You said you wanted a word that meant middling full. Well, why did you not say middling full - or fell mask ?" 
"Yes, why not?" demanded the ministers, unconsciously caught in the net.

"I wanted one word," replied Tommy, unconsciously avoiding it.

"You jewel!" muttered Mr. Ogilvy under his breath, but Mr. Cathro would have banged the boy's head had not the ministers interfered.

"It is so easy, too, to find the right word," said Mr. Gloag.

"It's no; it's as difficult as to hit a squirrel," cried Tommy, and again Mr. Ogilvy nodded approval.

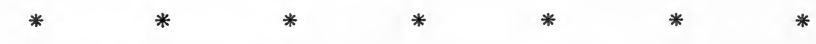

And then an odd thing happened. As they were preparing to leave the school [Cathro having previously run Tommy out by the neck], the door opened a little and there appeared in the aperture the face of Tommy, tear-stained but excited. "I ken the word now," he cried, "it came to me a' at once; it is hantle!"

Mr. Ogilvy . . . said in an ecstasy to himself, "He had to think of it till he got it - and he got it. The laddie is a genius!"

\section{Discuss Words with Those who Know Them}

Since public discourse closely follows the diction of every-day speech, many useful words may be acquired in conversation with cultivated men. And when such communication takes the form of disputation as to the meanings and usages of words, it must prove doubly valuable. 
HOW TO ACQUIRE AN ORATORICAL VOCABULARY 9I

5. Do not Overlook the Value of Translating Languages

\section{Study Word Derivations}

A notable sermon on "Joy," preached by the Rev. Dr. Maltbie D. Babcock, grew out of the orator's keen discriminations between the word joy and such kindred words as pleasure, happiness, amusement, and recreation. A flood of light may stream over a subject when the origin of a word is disclosed. A prefix or a suffix may essentially change the force of the stem, as in master-ful and master-ly, contempt-ible and contemptuous, envi-ous and envi-able. Thus to study words in groups, according to their stems, prefixes, and suffixes, is to gain a mastery over their shades of meaning, and introduce us to other related words.

\section{Do not Favor one Set or Kind of Words more than Another}

"Sixty years and more ago, Lord Brougham, addressing the students of the University of Glasgow, laid down the rule that the native (Anglo-Saxon) part of our vocabulary was to be favored at the expense of that other part which has come from the Latin and Greek. The rule was an impossible one, and Lord Brougham himself never tried seriously to observe it; nor, in truth, has any great writer made the attempt. Not only is our language highly composite, but the component 
92 HOW TO ACQUIRE AN ORATORICAL VOCABULARY words have, in De Quincey's phrase, 'happily coalesced.' It is easy to jest at words in -osity and -ation, as 'dictionary' words, and the like. But even Lord Brougham would have found it difficult to dispense with pomposity and imagination." 1

${ }^{1}$ Handbook of English Composition, Hart, p. $34 \mathbf{I}$. 


\section{CHAPTER XIII}

\section{STYLE IN PUBLIC DISCOURSE}

If I am ever obscure in my expression, do not fancy that therefore I am deep. If I were really deep, all the world would understand. - ChARLES KingsLey.

Clear writers, like clear fountains, do not seem so deep as they are. - Walter Savage Landor.

In the last chapter we saw the value of a large and accurate oratorical vocabulary. We are now to note by what means individual words are to become fused in the alembic of the soul and become a power in speech.

Walter Pater once said that a man should have "a vocabulary faithful to the coloring of his own spirit"; and Buffon wrote, "Style is the man himself." Both of these maxims recognize a truth fundamental to our theme -

\section{Personality must Dominate the Style in Public Discourse}

It is true that the qualities of Purity, Propriety, and Precision in diction, and of Clearness, Unity, Emphasis, Force, Harmony, and Vitality, in general composition, are of primary importance ${ }^{1}$ in spoken discourse as well

1 See pp. 100-108. 
as in written; it is furthermore true, as will presently appear, that other facts also help determine the style of the speaker; but personality must pervade and dominate them all.

"A poet is born; an orator, made," said Horace. This is only half true. The orator must possess certain native gifts which are susceptible to culture, and personality is one of these. Expression grows out of personality; hence the former must receive tone and spirit from the latter. When a man is surcharged with life, he can't help doing and saying things; if he did not, he would burst.

Thus we see that all the qualities and acquirements of manhood are influential in forming the speaker's style. He may simulate for a while the possession of qualities not his own, he may repress his real nature upon occasions, he may even act skillfully in delivering the words of others; but in the long run personality will color the matter as well as the style of his discourse.

According to the personality of the man and the "quality of the information in the treasure house of the understanding, will be the style - scant or plentiful in words, clear or confused in expression, vivacious or dull, yielding ideas leaden or golden, gems of paste, or diamonds rich and rare." 1

In view of this truth, let it be observed that modesty, sincerity, naturalness, earnestness, and all other personal characteristics, as revealed in style, cannot be 
taught by rhetoricians, but must be the outward expression of an inward character. The way to have them is to build them into the life. Then, and then only, can they find true expression.

The structure and the handling of language are indeed subjects of instruction; but only as instruments to convey thought, feeling, and will, are they part of the orator's equipment. His real power is from within. Personality is the dynamic of oratory. To cultivate it is the work of a life. First impression, then expression; first be, then speak; first will, then command. Do you suppose that anything other than the high plane of thought on which Gladstone constantly moved could have made possible and inevitable the lofty style which clothed his sentiments? Could aught but a spirit tremendously in earnest have given voice to such fervid periods as burned in the eloquence of Wendell Phillips? Could a heart less bound up in the interests of men and causes that he loved have inspired such bursts of moving appeal as gushed from the lips of Daniel Webster?

It is such full natures as these that give to their hearers the strong sense of power in reserve, and cause them to hang upon each word as it falls from the orator's lips as though within its compass were enfolded momentous issues. When such dynamic minds attempt utterance, quietness is not mistaken for dullness, nor gentleness for timidity. Theirs is not the gentleness of a limpid brook, which moves quietly because it has no 
power to rage; it is rather the sublime self-repression of the ocean when in placid mood. At any moment those gentle ripples may swell to mountains of irresistible power; and when once the rising tide of emotion breaks bounds within the orator's bosom, a wave of eloquence will sweep the sympathies of his audience along upon its towering crest.

This quality of individuality discloses itself in a score of ways, but nowhere more evidently than in style. Illustrations may be drawn from dress, from manners, from employments, from all life. Just so the orator will express his personality in his style; that is, his personality will so temper his use of the general qualities of style, will dictate their use in such combinations, as to produce his own style. To be sure, this development of a markedly personal style is to be looked for only in exceptional speakers; yet it is interesting to note how such individuality begins to show itself in a young speaker. A man of petulant nature will naturally adopt a short and crisp manner of expression; he who is easygoing and mild will reflect this temper in his speech; while the flustry, blustry fellow will lean to a style florid and wordy. It is precisely here that the value of rhetorical training appears, in that it gives the speaker command of such variety of expression that he may accomplish his end without either burying his personality or keeping it unpleasantly in the foreground. When the orator is at his best, all his words will be an adequate and sincere utterance of his best self. 
2. The Style of Public Discourse should be more Free than that of Written Discourse

The learned Dr. Gilchrist once wrote: "What one of the ancient philosophers said of laws may be truly said of rhetorical rules; they are like cobwebs which entangle the weak, but which the strong break through. The first rule of good composition is, that the composer be free and bold."

Truly, there are times when, as Pope declared, "A little knowledge is a dangerous thing." So long as the rules of rhetoric and logic are used as crutches, they cannot be shouldered and wielded as weapons. It is only when the technicalities of rule have been mastered and have become a sort of second nature that the writer or speaker moves with freedom and individuality. Be so familiar with the rules of discourse that they may be helps and not hindrances. Do not write by rule, but learn by rules how to write without rules.

"Prose is the literary evolution of conversation." 1 Therefore, the most natural and free public speech is conversational. But why emphasize this point here rather than in connection with delivery? Because there are so many like Tom Birch, of whom Dr. Johnson said, " $\mathrm{He}$ is as brisk as a bee in conversation; but no sooner does he take a pen in his hand than it becomes 
a torpedo to him, and benumbs all his faculties." To be able to write as though speaking to an audience is the highest attainment in preparation. In order to attain to this freedom it will be well to keep in mind several things : -

(a) You are delivering a message; be direct. - President Hyde, of Bowdoin College, relates how that a clergyman without a charge once came to the Rev. Dr. Joseph Parker, and asked to be helped to a parish. The great London preacher at once set his visitor to preaching a sermon. In the midst of its delivery. Dr. Parker interrupted with the pertinent comment, "Now I know why you do not have a parish, - you are speaking to get something off your mind, not into mine."

(b) Use the figures and idioms of every-day life.Don't go on stilts. Come down.

(c) Read aloud model orations to catch their direct, free style.

(d) Read aloud your own written preparation to see if it "speaks well."

(e) Use straight-forward declarative sentences freely. Avoid " the grand style."

(f) Hammer home important points by judicious repetition and summary.

(g) Don't speak over the heads of your audience. - Be intelligible and pointed.

(h) Never use the "editorial we," and seldom say "I." 
3. The General Style of Public Discourse must be determined by the Limitations of Speaker, Occasion, and Theme

As the speaker puts to himself this three-fold proposition, it will be seen that - the limitations of the speaker excepted, for of them he himself will be the best judge the problem of style will resolve itself into a question of occasion and theme. But these considerations determine the kind of discourse, therefore an examination of the subjoined outline will enable the speaker to suit the style of preparation to the kind of discourse he is to deliver. Further than this bare suggestion no directions will be attempted.

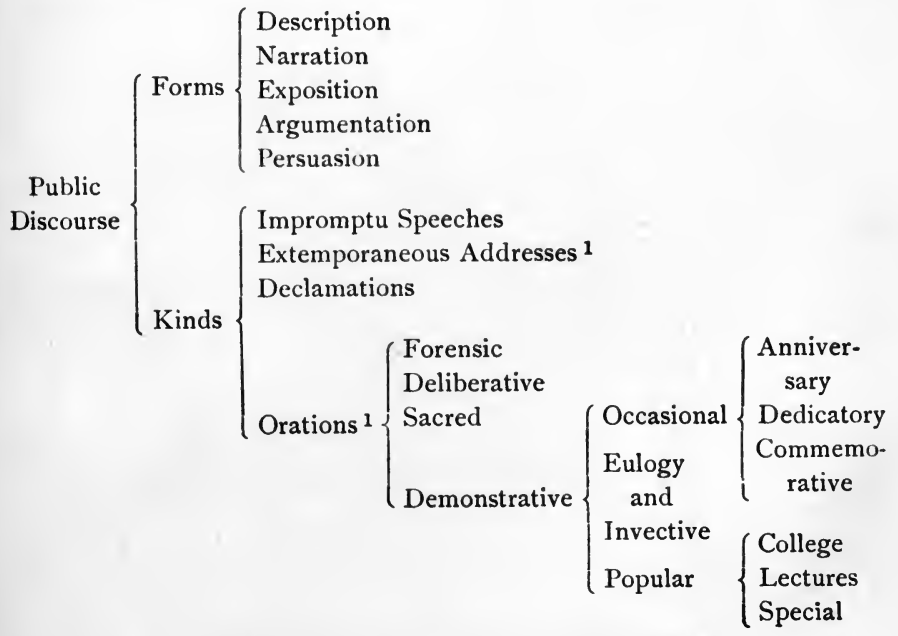

1 The oration is sometimes extemporaneous. 


\title{
CHAPTER XIV
}

DIGEST OF RHETORICAL RULES AS APPLIED TO PUBLIC DISCOURSE

Expression is the dress of thought, and still Appears more decent, as more suitable;

A vile conceit in pompous words express'd, Is like a clown in regal purple dress'd.

- Pope, Essay on Criticism.

\section{Diction - The Right Use of Right Words}

\begin{abstract}
I. Use neither obsolete words, nor words too new to be standard.

2. Avoid the use of localisms and tech-

(a) Pure nical terms in a popular address.

Words $\{3$. Do not employ a foreign word until it has become naturalized.

4. Follow the usage of the best speakers by refraining from slang, and from words not properly in the language.
\end{abstract}

\footnotetext{
5. Be too alert to use the wrong word

(b) Proper $\quad$ even if it sounds like the right one. Words

6. Do not use a word in more than one sense in the same paragraph.

7. When in doubt, consult the dictionary. 100
} 


\section{(c) Precise Words \\ 8. Among synonyms, use the word which conveys exactly your shade of meaning, both as to kind and as to degree. \\ 9. Simple words are most effective.}

\section{Sentences}

Io. Short sentences should be used for vigor, emphasis, rapid movement, and impassioned discourse.

I I. Too many short sentences produce a disconnected, jerky effect.

12. For detail, smoothness, and rhythm, use long sentences.

13. Use care lest long sentences conKinds fuse the meaning.

14. Use balanced sentences to bring out contrasts.

I5. To sustain interest, use periodic sentences.

16. For easy and informal discourse use loose sentences.

17. By no means confine yourself to any one kind, but learn to use all varieties of sentences. 
(a) Grammatical

iII. Essential Properties of Style Correctness

I8. "Confine the possessive mostly to persons." - Genung.

19. Use the subjunctive only when the condition is doubtful.

20. Use shall and will with care.

2r. "Do not let intervening words disturb the agreement of verb and subject." - Genung.

22. Never place an adverb between the parts of an infinitive.

23. Let the sense rather than grammar govern your treatment of collectives.

24. Place adverbs and adverb modifiers close to the words they modify.

25. Place a restrictive modifier where there can be no doubt as to what it modifies.

(b) Clearness $\{26$. "Between a word and its modifier do not put anything that can steal the modification." - Genung.

27. Be certain that each relative pronoun points clearly to its antecedent. 
28. A clause should not be used as the antecedent of a relative pronoun.

$\frac{\text { Clearness }}{(\text { Continued })}$

29. Let there be no doubt as to which, of two or more nouns of like number and gender, a personal pronoun relates.

30. Omit no parts not evidently implied (understood).

3r. During the course of a sentence do not change its subject or shift the standpoint of thought.

32. The sentence should be completely dominated by one main thought, and upon it directly should each subordinate thought depend.

33. Do not crowd together conflicting

ideas, nor thoughts not naturally related.

(c) Unity

Do not attach relative clauses to other clauses which are themselves dependent.

35. A too free use of parenthetical expressions tends to switch thought away from the subject.

36. Do not attach a supplementary expression to the end of an already complete sentence. 
IV. Special Properties of Style

(a) Emphasis

37. For emphasis, accord a conspicuous place in the sentence to the main idea, using the other parts as a background.

38. Invert the position of the modifier to give it emphasis.

39. An inverted sentence-order will emphasize the logical subject, or principal idea.

40. By putting subsidiary matter first, the logical subject will be emphasized (periodic sentence).

4I. Repetition, both of words and of sentence-forms, adds emphasis.

42. Use climax.

(b) Force

43. Plain, specific, short, and strong words give vigor to sentences.

44. Avoid' useless repetition of ideas, and the use of unnecessary words.

45. "End with words that deserve distinction." - Wendell.

46. For weighty force, cut out modifiers, condense clauses and phrases to equivalent words, and choose the most emphatically direct words.

47. Cut out superfluous connectives. 
48. To secure harmony adapt the sound of words to the sense.

49. Select synonymous words when it is necessary to repeat ideas.

(c) Harmony $\{$ 50. Use alliteration sparingly.

51. Arrange your material with an ear to the prevalence of harmonious sounds.

52. To give vitality to discourse, use direct, idiomatic English.

53. Distinguish between an idiom and

a worn-out stock expression.

54. Avoid the use of poetic forms.

(d) Vitality $\{$ 55. Beware the pitfall of a stilted and exaggerated style.

56. Rapid movement is secured by suppressing details, and using epithet to portray the characteristic points.

57. For condensed and vivid descrip- tion, use simile, metaphor, allu-

- sion, and personification.

(e) Figures 58. Interrogation, exclamation, and hyperbole are used for impressive assertion.

59. Apostrophe, and vision (the histori- cal present), are suited to dramatic narration. 
$\frac{\frac{\text { Figures }}{\text { of Speech }}}{(\text { Continued })}$

6o. For illustration, study the use of figures of comparison, as well as the handling of allegory, parable, and fable.

6r. Do not use figures except where you desire to add clearness, force, or beauty.

62. Figures should harmonize with the general character of the discourse.

63. Vary the use of figures by studying many different objects for suggestions.

64. Do not in the same sentence mix figures of speech with literal language.

65. Figures should neither be carried, so far as to be incongruous, nor be used to excess.

V. VARIETy OF EXPREsSion For Repeated IdeAs

Means of $R e$ 66. Empløy synønyms.

67. Leairn the use of denying the cøn trary of a prøposition (lit॰tes).

68. Used guardedly, circumløcution fur nishes variety.

peating Ideas

69. Study the art of recasting sen tences.

70. Have recourse to epithet.

7 I. Figures of speech afford variety. 
72. Use declarative, interrogatory, and exclamatory forms interchangeably.

73. Expression may be varied by changing the voice of the verb.

74. Study the inversion produced

Means of $R e$ peating Ideas (Continued) by introducing sentences with " there" and "it."

75. Learn to vary from direct to indirect quotation (discourse).

76. Employ the historical present.

77. Paraphrase poetic into prosaic language.

78. Practice contracting clauses into phrases and into words; and contrariwise, expanding words and phrases into clauses.

\section{The Thought-Divisions}

Relation of Thoughts
79. Each division of the whole discourse should be dominated completely by one main thought, and upon it directly should each subordinate thought depend.

8o. Each such thought-division must preserve its unity by including only its own logical material. 


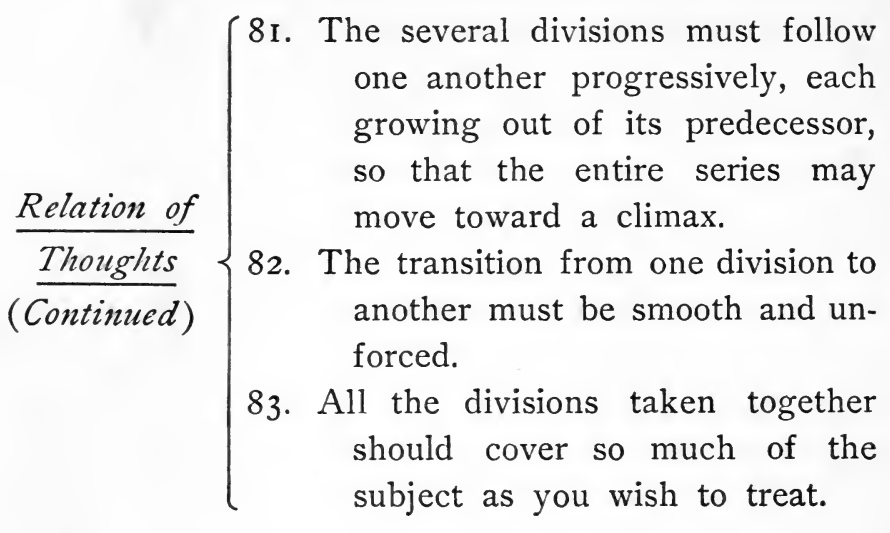

\section{The Whole Discourse}

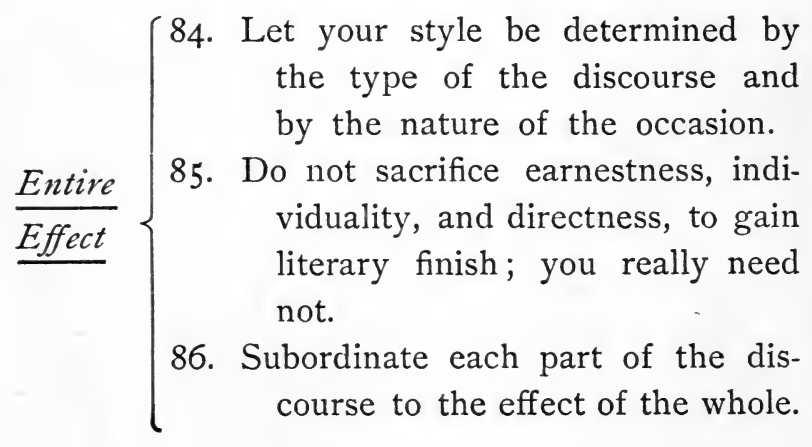




\section{PART III}

PREPARATION OF THE SPEAKER 
Speak not at all, in any wise, till you have somewhat to speak; care not for the reward of your speaking, but simply and with undivided mind for the truth of your speaking.

- Thomas Carlyle, Essay on Biography.

Education is the knowledge of how to use the whole of oneself. Many men use but one or two faculties out of the score with which they are endowed. A man is educated who knows how to make a tool of every faculty - how to open it, how to keep it sharp, and how to apply it to all practical purposes. - HENRY WARD BEECHER. 


\section{PART III}

\section{PREPARATION OF THE SPEAKER}

"The true orator speaks with his entire personality, with all the powers of his being, and for that reason, .. preceding his address, he should summon and concentrate all his instruments." 1

This culminating point of preparation brings the orator face to face with himself. Whatever of promise he may have put into his prepared discourse, it now rests with him to drive it home, true and strong, as a shaft to its target. But this cannot be done without a special kind of personal preparation, which, under three heads, we shall now briefly consider. Just how much time is to be given to this girding of the loins before the race will depend upon circumstances, and upon his previous training; but no speaker can afford to face his audience without serious attention to this three-fold preparation.

1 Art of Extempore Speaking, Bautain, p. 207. 


\section{CHAPTER XV}

\section{MENTAL PREPARATION}

Things done well, And with a care, exempt themselves from fear.

- Shakespeare, Henry VIII., Act I. Scene $2 \bullet$

When the discourse is once committed, wholly or in part, to writing, a sense of relief comes to the orator; he has delivered himself of a burden, but only to take it up again in a new form. And just here appears a danger, - that the mind may lose its sympathetic identity with the thing it has just produced.

\section{Gripping the Discourse}

Did your spirit glow during the writing, as thought after thought came to your mind, pleading for adequate expression? Then in your final preparation let those same thoughts kindle anew the glow, or melt your spirit in tenderness. Surrender your being into the possession of the message which you are to bear to living men and women. Or, as is too often the case, did thought flow sluggishly and emotion respond but feebly? All the more reason then to grip masterfully 
the completed thought and let it do, as a rounded, perfected unit, that which it could not do while as yet it was constructing: transfuse your being - to use Matthew Arnold's expressive phrase - with its "sweetness and light."

$\mathrm{Be}$ it remembered that these maxims apply quite as directly to the entire discourse as to any of its more striking parts. If you would leave a single, compact, powerful impression upon your audience, give soul-room to that impression yourself. Hold it up before your inner vision, epitomize it, let your imagination play upon it, see it in all its relations, realize the succession and inter-dependence of its divisions; grip it!

There is no better spirit than this with which to approach the work of memorizing for delivery. If the effort is to be a declamation, and the composition therefore the work of another, none the less must the mind be widely opened to receive the spirit of the selection. How did the speaker feel when he delivered the words? What audience sat before him, and upon what occasion? The appreciation of such considerations as these will change the work of memorizing into that of interpreting the spirit of the production - the order of the words will come with the mastery of the thought. The same is true of committing your own composition, whether in full or in outline. ${ }^{1}$

1 Those who would confine their public efforts to extempore speech are referred to the following excellent manuals: The Art of Extempore Speaking, Bautain; Before an Audience, Sheppard ; Extempore Speech, Pittenger. 


\section{Conserving Energy}

But gripping the discourse is not all of the work of mental preparation. The Rev. Dr. Parkhurst once lamented the popular inability to remain indignant, and assigned this as the reason why so many reform movements "peter out." How many an address, conceived in warmth, written in a glow, and begun with ardor, has "petered out" before an audience, from sheer lack of energy.

The athlete never does his utmost until he is actually competing for the prize. So must the orator conserve his energies. Physical conditions have a large influence here, but the trouble is chiefly mental.

After a certain point has been reached in your personal preparation, it is time to stop. A breathing spell is needed. Liken this to the soldier sleeping on his arms, to the lull before the conflict, to the calm before the storm; but by no means disregard it. A period of recuperation after mental strain - a period neither so long as to invite lethargy nor so short as to be useless - will be of incalculable value in sending you fresh and self-controlled to the platform.

The practice of orators differs widely in this respect. Some will work on their preparation until the last moment, and then rush before the audience with the glow of the final hour still suffusing them; while others habitually lay aside their manuscripts hours before delivery. The latter - and these seem to be the nor- 
mal public speakers - reserve the final hours for rest, for a short walk amid scenes of nature's beauty, for a stimulating book, for a pleasing conversation, - for something, for anything, so that they may be delivered from an exhausting nightmare of fear and trembling.

Who that has ever suffered it can forget the fearful heaviness, depression, and foreboding that will sometimes weigh upon the speaker just before he mounts the platform! Some find relief in the devices already mentioned, but nothing, it is said, can compose the nerves and lift the depression of some orators in those racking minutes. But, the opening sentences once pronounced, there often follows a stimulating elation as delightful as the mood of a moment before was distressing.

Human nature is cast in many molds. The author has known effective speakers who declare that their efforts are sure to be dull and lifeless unless they approach the rostrum with the very feelings of depression just described. Others, again, will even sleep immediately before speaking. The general rule holds: it is fatal to spend all the energies before the hour of delivery. 


\section{CHAPTER XVI}

\section{PREPARATION FOR EXPRESSION BY VOICE}

The tones of human voices are mightier than strings or brass to move the soul. - KLOPSTOCK.

The technical preparation of the speaker may mean much or little - it depends upon his object. There is a sense in which mental preparation covers the whole of education; and so technical training - in voice, attitude, and gesture - may be made the subject of exhaustive study, or simply of daily common-sense practice. If you expect to become an actor or a dramatic reader, you must follow the teaching of the schools; but if you are resolved to be an attractive platform speaker, you must teach yourself.

Does that mean that a teacher can do you no good? It means that he can do you no good unless you take his suggestions and become your own critic. You live with yourself, and so can hear yourself talk as often as you open your lips. Listen, and hear how your voice sounds. Cultivate what Nathan Sheppard calls the " ear for your own voice." 1

The basis of the maxims which follow in this chapter is a very simple one, but it contains a world of meaning:

1 Before an Audience, p. 18. 
You must enthrone your will. Will-power will enable you to change your voice from a squeaking-machine into an instrument of power; it will enable you to make what tones you wish, how you wish, and when you wish. As soon think of having an unmanageable foot, that kicks and jerks when you least expect, as of having a recąlcitrant voice, that goes up and down without consulting you.

You cannot do this by trying to manage your voice only when you are speaking in public or rehearsing for a public effort. You must fail if you try that. Master your voice in conversation. What you habitually do well in private speech you will do well in public discourse. Oratory is not a dress-suit any more than are good manners - neither the one nor the other can be donned for the occasion. Practice the succeeding exercises, not for effect, but to secure perfect control. Do not rest until you have made your voice so obedient that you will use the full, round, barytone in conversation as habitually as a good speaker uses it in oratory. This is the only way to secure power, flexibility, and naturalness. Whenever you speak, make your voice obey your will.

The accompanying principles are not a system of elocution. That is not what you need. They are suggestions gleaned from many sources, all tested by years of use-and all of no value unless you apply them under the domination of your will. Let your motto be, My will SHALl CONTROL My voice. 


\section{Hygiene of the Voice}

( I) Good health, sensible diet, and clean living are essential to a good voice.

(2) Avoid patent medicines - consult a throat specialist if your throat is sore.

(3) Use only cold water in bathing the neck and throat.

(4) Tight collars, alcoholics, narcotics, and sweetmeats will inflame a sensitive throat.

\section{Breathing}

(5) Habitually breathe with the mouth closed; if you can't, find out why you can't. ${ }^{1}$

(6) Practice deep breathing. ${ }^{2}$

\section{Elements of Expression}

(7) Vary the quality of the voice to suit the sentiment.

\section{EXAMPLES}

PURE : "Listen, my children, and you shall hear Of the midnight ride of Paul Revere."

OROTUND: "Roll on, thou deep and dark blue ocean, roll !" Aspirate: "Hush! sure, you heard it then!"

GutTURAL: "Let the carrion rot!"

(8) Vary the force of the voice so as to assist expression.

${ }^{1}$ Habitual Mouth Breathing, Wagner.

${ }^{2}$ Art of Breathing, Kofler. 


\section{EXERCISES}

Soft to Loud: I do NOT BELIEVE IT AT ALL !

LOUD TO SOFT: NEVER will $I$ consent !

LOUD, SOFT, LOUD : HOW STRONG soever may be OUR DEMANDS. SOFT, Loud, SofT: Even though you ADMIT THIS absurd claim.

$$
\begin{array}{r}
\text { A - WAY! A - WAY! } \\
\text { FOR - ward! FOR - ward! }
\end{array}
$$

(9) Vary the pitch of the voice to express shades of thought and feeling, and to avoid monotony.

\section{EXERCISES}

(Use your will, and so place your tone at any pitch you wish.)

\section{High : No !}

MIDDLE : No!

\section{Low : \\ NO !}

Say "Xes" so as to express (a) Contempt, (b) Conviction, $(c)$ Uncertainty, $(d)$ Tenderness, (e) Indignation, ( $f)$ Other emotions. Try the same process with "No."

See with how many different emotions you can pronounce the word "What," noting how you unconsciously vary the pitch.

LAUGHING SURPRISE :

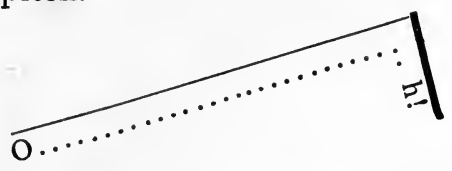

High.

Low: Is this the work of honest men? 


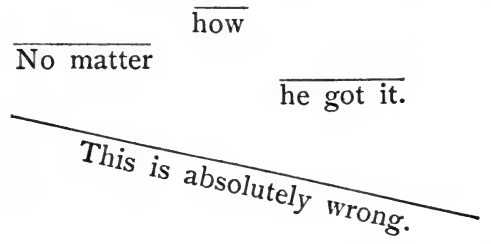

(I0) Vary the time to suit the spirit of the passage.

\section{EXERCISES}

SLow : "I will lift up mine eyes unto the hills from whence cometh my help."

HuRRIED: Run quickly, and summon the guard !

INCREASING: And do you dare to scorn me thus?

BROKEN : I - a poor, decrepit nan - reduced - to - beggary - am to become your - heir?

Moderate: These, then, are the considerations which should affect you.

(I I) Increase of time should generally be accompanied by increase of force, and variation of pitch (inflection).

\section{EXAMPLE}

Time Increasing: And do you DARE IO SCORN
(I2) When you decrease the time, lower the pitch.

\section{EXAMPLE}

Solemnly : "I | am | thy | father's | spirit."

(13) Beware of monotony of either pitch or time - both must constantly change. 
(I4) A pause is (generally) made where you would place a punctuation mark, - to indicate a break in the thought-movement.

(15) Emphasis is attained in any of the seven ways illustrated below.

\section{EXAMPLES}

INCREASED FORCE: A practice I have hated all my life.

Contrasted Force: "Socrates died like a philosopher; Jesus

Christ died like a God."

DECREASED ForCe: Let me whisper that fatal word - treason!

PaUSE: "Made way for liberty - and died!"

VoICE QuALITY: Well, did he snarl? (Guttural.)

Sound out the truth like thunder! (Orotund.)

I can hear the swish of the task-master's whip. (Aspirate.)

\section{VARIED PrTCH : That man my brother?}

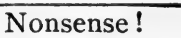

Prolonged Utterance: How he dr-aw-l-s his words.

(16) Thought, not rule, governs emphasis; such words and passages as contain the gist of the sense must be made to stand out.

(I7) The elements of expression are to be used in combination, - it is this which gives such infinite variety to expression.

(I8) First learn to hear yourself speak; then let your will so dominate your voice that you can change its quality, control its force, place its pitch (tones), 
regulate its time (rate of speech), and direct its emphasis, that it will obey you as promptly as the fingers respond to the will of a pianist.

(19) Invent other exercises based upon the principles expressed in the preceding maxims.

\section{Pronunciation}

In popular usage, pronunciation, enunciation, and articulation are synonymous terms; but in reality pronunciation includes three distinct processes, and may therefore be defined as, the utterance of a word or of a syllable with regard to its articulation, accentuation, and enunciation.

This is one of the most important considerations of public speech. How preposterous it is to hear a speaker making sounds of "inarticulate earnestness" under the fond delusion that he is telling something to his audience! Telling? Telling means communicating by word of mouth, and how can he tell without making every word distinct?

Slovenly pronunciation, in the three-fold sense of articulation, accentuation, and enunciation, results from either physical deformity or habit. Will-power in self-observation, and resolution in drill, will break the habit. All depends upon whether you think it worth while.

This defect is so widespread that freedom from it is the exception. It is painfully common to hear public 
speakers mutilate the king's English. If they do not actually murder it, as Curran once said, they often knock an $i$ out.

A Canadian clergyman, writing in the Homiletic Review, relates that in his student days "a classmate who was an Englishman supplied a country church for a Sunday. On the following Monday he conducted a missionary meeting. In the course of his address he said some farmers thought they were doing their duty toward missions when they gave their 'hodds and hends' to the work, but the Lord required more. At the close of the meeting a young woman seriously said to a friend : ' I am sure the farmers do well if they give their hogs and hens to missions. It is more than most people can afford.' "

By what right does any man so impose upon the public as to garble his mother tongue before an audience? It is insufferable effrontery for a man who persists in driving the $h$ out of happiness, home, and heaven, to attempt to be a public educator, as all speakers are. $\mathrm{He}$ does not show enough self-control even to correct his errors. If he can do no better, he should be silent. If he will do no better, he should also be silent. If he really wishes to do better, he can, by observing his pronunciation and correcting its defects. It would weary you to hear the roll called of those eloquent and forceful orators who resolutely overcame slovenly habits of speech.

Excepting insuperable physical deficiencies, and rare 
natural gifts, the whole question is one of will. "The less there is of yourself the more need for you to make the most of what there is of you." 1

Each of these three elements of accurate pronunciation must now be examined. No one who would attract and hold an audience can afford to disregard any of them.

(a) "Articulation is the formation, and jointing together into syllables, of the elementary sounds of speech." 2

From the forty-four elementary sounds in our language are produced the (about) one third of a million distinct words which go to make up our English vocabulary. It will be conceded that the right use of these elemental sounds is important indeed. Many can glibly recite them all; but how few approach correct usage!

Where lies the trouble?

Aside from physical defects, which only the skill of a surgeon or of a dentist can remedy, the real difficulties are to be found in four evident facts: ignorance of the elemental sounds; failure to discriminate between sounds nearly alike; a slovenly, lazy use of the vocal organs; and a torpid will. Any one who is still master of himself will know how to handle each of these defects.

The vowel sounds are the most vexing source of errors, especially where diphthongs are found. What

1 Before an Audience, Sheppard, p. 21.

2 Elocution, McIlvaine, p. 199. 
refined ear has not quivered to hear such errors as are humorously hit off in Dr. Holmes's inimitable verse:-

"Learning condemns beyond the reach of hope The careless lips that speak of sŏap for sōap;

Her edict exiles from her fair abode

The clownish voice that utters rŏad for rōad;

Less stern to him who calls his cōat a cŏat,

And steers his bōat believing it a bŏat.

She pardoned one, our classic city's boast,

Who said at Cambridge, mǒst instead of mōst,

But knit her brows and stamped her angry foot

To hear a Teacher call a rōt a rōt."

No one seems to find it difficult to say beauty, but many persist in articulating duty as though it were spelled either dooty or juty. No more do we hear few uttered as foo, but how few articulate new as they do few? It is not only from untaught speakers that we hear such slovenly articulations as certen for certain, pritty for pretty, crick for creek, but even great orators occasionally offend quite as unblushingly as less noted mortals.

The most common errors in articulating vowel sounds are found in uttering words of the kind already noted. Nearly all are errors of carelessness, not of pure ignorance, - of carelessness because the ear never tries to hear what the lips articulate. To be sure, it must be exasperating to a foreigner to find that the elemental sound ou gives him no hint for the articulation of bough, cough, rough, thorough, and through. We can 


\section{I26 PREPARATION FOR EXPRESSION BY VOICE}

well forgive even a man of culture who occasionally loses his way amidst the intricacies of English articulation, but there can be no excuse for the slovenly utterance of the simple vowel sounds which form at once the life and the beauty of our language. $\mathrm{He}$ who is too lazy to speak distinctly should hold his tongue.

The consonant sounds can occasion serious trouble to those only who do not look with care at the spelling of words about to be pronounced. Nothing but carelessness can account for saying Jacop, Babtist, sevem, alwus, or sadisfy.

"He that hath yaws to yaw, let him yaw," is the rendering which an English clergyman gave of the familiar scripture, "He that hath ears to hear, let him hear."

After hearing the name of Sir Humphry Davy pronounced, a Frenchman who wished to write to the eminent Englishman thus addressed the letter: "Serum Fridavi." Pronounce the proper name as carelessly as men usually do, and then say if the Frenchman did not do quite well.

(b) Accentuation is the process of placing stress upon the proper syllables of words. This is what is popularly called pronunciation. For instance, we properly say that a word is mispronounced when it is accented $i n^{\prime}$-vite instead of in-vite', though it is really an offense against only one form of pronunciation.

It is the work of a lifetime to learn the accents of a large vocabulary and to keep pace with changing 
usage ; but a keen ear, the study of word-origins, and the dictionary habit, will prove mighty helpers in a task which can never be perfectly consummated.

(c) Correct enunciation is the complete utterance of all the sounds of a syllable or a word. Wrong articulation gives the wrong sound to the vowel or vowels of a word or a syllable; wrong enunciation is the incomplete utterance of a syllable or a word, the sound omitted or added being usually consonantal. To say chuck-full instead of chock-full is a wrong articulation; to say doin for doing is improper enunciation. The one gives the word a positively wrong sound; the other fails to touch all the sounds in a word, or carelessly adds a sound not to be properly found there.

“ My tex' may be foun' in the fif' and six' verses of the secon' chapter of Titus; and the subjec' of my discourse is 'The Gover'ment of ar Homes.' " 1

What did this preacher do with his final consonants? This slovenly dropping of essential sounds is as offensive as the common habit of running words together so that they lose their individuality and distinctness. Lighten dark, uppen down, doncher know, up te date, lots $o$ ' snow, zamination, are all too common to need comment.

Imperfect enunciation is due to lack of attention and to lazy lips. It can be corrected by resolutely attending to the formation of syllables as they are uttered. Flexible lips will enunciate difficult combinations of sounds 
without slighting any of them, but such flexibility cannot be attained except by habitually uttering words with distinctness and accuracy. A daily exercise in enunciating a series of sounds will in a short time give flexibility to the lips and alertness to the mind, so that no word will be uttered without receiving its due complement of sound.

Sound every consonant in the following

\section{EXERCISES}

"Foolish Flavius, flushing feverishly, fiercely found fault with Flora's frivolity." 1

Mary's matchless mimicry makes much mischief.

Seated on shining shale she sells sea shells.

You youngsters yielded your youthful yule-tide yearnings yesterday.

Returning to our definition, we see that when the sounds of a word are properly articulated, the right syllables accented, and full value given to each sound in its enunciation, we have correct pronunciation. Perhaps one word of caution is needed here, lest any one, anxious to bring out clearly every sound, should overdo the matter and neglect the unity and smoothness of pronunciation. Be careful not to bring syllables into so much prominence as to make words seem long and angular. The joints must be kept decently dressed.

Before delivery, do not fail to go over your manu-

${ }^{1}$ School and College Speaker, Mitchell, p. xxix. 
script and note every sound which may possibly be mispronounced. Consult the dictionary and make assurance doubly sure. If the arrangement of words is unfavorable to clear enunciation, change either words or order, and do not rest until you can follow Hamlet's directions to the players :-

"Speak the speech, I pray you, as I pronounced it to you, trippingly on the tongue: but if you mouth it, as many of our players do, I had as lief the town crier spoke my lines." 1

${ }^{1}$ Act III. Scene 2. See also pp. 159, 160. 


\section{CHAPTER XVII}

\section{PREPARATION FOR EXPRESSION BY ACTION}

Action is eloquence, and the eyes of the ignorant

More learned than the ears.

- Shakespeare, Coriolamus, Act III. Scene 2.

In one aspect, the matters touched upon in this chapter belong in strictness to the subject of delivery, but since those who would turn these hints into helps must make use of them while preparing, the existing arrangement is probably better.

There are two points to bear in mind here. First, Action is expression. Wherefore, do those things, and those things only, which help to carry your thought and feeling effectively home to your audience. Words are cold without action. Smiles and tears, caresses and blows, movement and gesture, are all gifts of a beneficent Creator, intended to express the self within. Voice is expression appealing to the ear. Action is expression appealing to the eye.

Two men are accused of wrong-doing. Neither of them speak a word, yet both are expressing themselves. See the indignant surprise gleaming from the face, straining from the tense limbs, quivering in the whole action, of the one. See the hang-dog spirit that utters itself in every pose and movement of the other. Actions 
speak louder than words. True, we may be deceived by both, but action comes the more sincerely to the surface. The very look of an intensely earnest man is eloquent. Action is expression. What have you to express? No man can be magnetic with nothing in his mental and spiritual battery. First let your message kindle your soul. Then make your soul kindle your body. Both together will kindle any audience. Hence the second point:-

II Action must be kindled and controlled by will. When it is not, a man is dreaming, or nervous, or crazy. Do not let your legs"and arms manage you-manage them. Does that mean that you must be always thinking of your movements? Are you always thinking of your feet in company? You keep them where they belong, with the least possible attention. Just so you must subject your body to your will, that you may be able to put your trunk and limbs anywhere you want them to be, and make them stay there until it is proper to move.

\section{Carriage}

Healthy muscles are easily controlled. Therefore, exercise your body. It is beginning at the wrong end to tell a man not to plunk down his feet with a thump, not to stand "pigeon-toed" or with feet pointed aggressively straight toward his audience, not to shift nervously from one foot to the other, not to lose his balance, not to walk as though he had spent all his life in 
jail; all this is beginning at the wrong end. The head controls the feet - or ought to. Let the will take care of the legs, and soon the maxims of the elocutionist will become unnecessary. Not all men are graceful; not all men can be; but all men can put erectness, selfrespect, decision, and self-control into their carriage. There is no difference between walking respectably in a drawing-room and walking easily on the platform. If the chin and abdomen are thrust forward and the chest depressed in every-day life, the clothes will not fit when an erect carriage is attempted before an audience. Carriage must become habitual. It requires muscle to keep the chest up and chin in, - muscle and will.

It is not denied that directions as to how to stand and walk are valuable. They are. But what is insisted upon is that presence must express attitude of mind and feeling, and that the will must control: in a word, that the way to look like a man is to be a man.

" Only be natural," say the manuals. It will not do for some men to be natural. That were too bad. "It is perfectly natural," says Nathan Sheppard, "for some people to lose their heads just when their heads are most needed." Be natural, is not safe advice ; but it is safe to urge a man to be his best possible self when he speaks in public - as well as when nobody sees him.

\section{The Head and Face.}

All that has preceded in this chapter may well apply to the head and face. A wobbly head, frenzied eyes, 
nervous grimaces, unconscious scowling, all can be stopped by resolution; but it cannot in a moment supply the lack of soul. Light of eye, lines of face, poise of head, are expressions of something inside. If that something is not within, put it there. When trees do not bear fruit, men get at their roots; they do not tie fruit upon the branches. Cultivate your soul. If you have an earnest spirit, form the habit of expressing it in your features.

Test this. Awaken within yourself successively the emotions of Depression, Exaltation, Joy, Affection, Adoration, Confidence, Doubt, Suspicion, Arrogance, Contempt. Let the head change its position, the eyes their light, and the face its lines, so as to express each emotion in turn. Do this, not by thinking how you have seen others act in such moods, but observe how you would express it if you were mute and your life depended upon making some one else understand your feeling by your head and face alone. Test this.

What an inspiration it is to look into the faces of some speakers! How wooden are others, and how are their thoughts handicapped in their utterance. A mobile, sensitive, expressive face is as much a matter of habit as brushing the teeth - and to the public speaker quite as imperative a duty.

\section{Gesture}

"When Voltaire was preparing a young actress to appear in one of his tragedies, he tied her hands to her sides with pack thread in order to check her 


\section{34 PREPARATION FOR EXPRESSION BY ACTION}

tendency toward exuberant gesticulation. Under this condition of compulsory immobility she commenced to rehearse, and for some time she bore herself calmly enough; but at last, completely carried away by her feelings, she burst her bonds and flung up her arms. Alarmed at her supposed neglect of his instructions, she began to apologize to the poet; he smilingly reassured her, however; the gesture was then admirable, because it was irrepressible." 1

Problems differ. The author's difficulty has been to get pupils to become so enthusiastic as to break the pack thread of their own inert delivery. It is comparatively easy to repress vivacity. Anybody can grow cold, not every one can become hot in public speech. The lack of physical earnestness has killed more speeches than has over-demonstration. Both are evils, but fly to the latter rather than embrace the former. Voltaire's actress had too much spirit, most public speakers have too little. Let it not be overlooked, however, that pounding the desk is not expounding the subject.

So gesture is more than the explosion of physical earnestness. It is also a medium of expression for thought, feeling, and will. How you gesticulate must depend upon these conditions.

The gesture of the actor is not that of the public speaker. The speaker does not sink himself in the character whose words he is repeating in either illustration or declamation. $\mathrm{He}$ is still himself, and a too exact

1 The Actor's Art, Redway, p. 48. 
personation is offensive. The speaker "must suggest the picture and allow the imagination of the audience to paint it. . . T The drawing of a dagger may be indicated, but there is no necessity for sheathing it." 1

But if the orator may not adopt the methods of the actor, he may at least learn from him a lesson in dramatic earnestness - a lesson, however, not to be found in books. If it kindles in the heart it will suffuse the body and burst out in the flame of ation. Moral earnestness and physical vim God yoked together; let no man divorce them. See to it that a reality of belief in your theme, a realization of its importance, exists in your heart, and then you will not need to act, for you will express. The actor may teach you how to use physical earnestness, but moral earnestness must be yours before you begin.

George Whitefield, the early Methodist preacher, attained to such dramatic power of utterance that Garrick became jealous, while the skeptic Hume "went great distances to hear doctrines that he detested delivered in a style that fascinated him."

One day, while preaching, Whitefield "suddenly assumed a nautical air and manner that were irresistible with him," and broke forth in these words: "Well, my boys, we have a clear sky, and are making fine headway over a smooth sea before a light breeze, and we shall soon lose sight of land. But what means this sudden lowering of the heavens, and that dark cloud arising

1 Practical Elocution, Fulton and Trueblood, p. 341. 
from beneath the western horizon? Hark! Don't you hear distant thunder? Don't you see those flashes of lightning? There is a storm gathering! Every man to his duty! The air is dark! — the tempest rages! our masts are gone!-the ship is on her beam ends! What next?" At this a number of sailors in the congregation, utterly swept away by the dramatic description, leaped their feet and cried: "The løngbøat! take to the løngbøat!" 1

Upon another occasion, "when Whitefield acted an old blind man, advancing by slow steps toward the edge of the precipice, Lord Chesterfield started up and cried, 'Good God, he is gone!' " 1

You can do this if there is a Whitefield under your vest. At any rate, you can be your best possible self. David could not fight in Saul's armor, but he slew the giant with a pebble from the brook.

But, it is said, have you no rule for making gestures? Yes, one: Think! Observe, imitate, practice, of course; but think. Does it require anything more than cool thinking to enable the veriest novice to evolve the following rules, all seriously set forth in manuals of Elocution?-

"Avoid awkwardness."

"The Fist gesture represents that which is forcible in its character, addressing itself to the will and the activities; when used descriptively, it represents that which can grasp, confine, or control."

1 Before an Audience, Sheppard, p. 88. 
“The Hand Index points out, counts, analyzes, warns, accuses, threatens."

"Do not make too many gestures with one hand."

"Don't hold the hands as though you had bird-shot in each hollow, and feared that it would roll out."

"In the act of sitting, the body should be in front of the chair, and the back toward it."

Upon reading such inspiring directions one feels the irresistible impulse to cry out, Of course! Some things may with safety be left to common sense. The author has never yet found a pupil who hankered to sit down while his body was back of the chair. It is futile to give directions to imbeciles, but the earnest speaker may find out the points of gesture by thinking. Holyoake says, "Sincerity is not always elegance, nor is earnestness always grace; nevertheless, earnestness is the best schoolmaster in gesture - if, it may be added, earnestness has learned to think."

"Back to nature," the philosophers are crying. Let us echo the cry. Observe the human form in all its moods, catch inspiration from great speakers, study the poses reproduced by the master painters, emulate the freedom and dignity the ancient sculptors carved in their deathless marbles - Think! WILL! 


\section{CHAPTER XVIII \\ PREPARATION BY DRILL}

Suit the action to the word, and the word to the action.

- Shakespeare, Hamlet, Act III. Scene 2.

Not every one makes a practice of rehearsing an address; not every one should. The remarks in this chapter are directed to those speakers, especially college declaimers and orators, to whom rehearsal is important.

Let it be remembered that there are some things rehearsals can do, and some things they cannot. They are useful in discovering whether the written discourse is suited to public utterance - is the introduction easy, are the climaxes well arranged, is the style direct and forceful, is the conclusion effective? If not, remedy the defect at once.

Again, rehearsals will reveal defects of utterance, bearing, and gesture. How fully such weaknesses may be removed in the short time allotted for rehearsal is an individual problem.

Upon the other hand, private drill can give you no adequate impression of the power of your audience to hinder or to help. The fright and the stimulus alike 
are lacking. Therefore, do not place all reliance in rehearsal, but reserve your forces of self-command and resourcefulness to the hour of delivery.

\section{General Suggestions}

The first step is to read the production aloud so as to interpret it intelligently. The next is the work of memorizing. Not until these two important preliminaries have been disposed of should the regular rehearsals begin.

Do not rehearse so long and so often as to rob your efforts of zest, nor so infrequently as to send you to the platform illy prepared. In training for a contest, the athlete takes care to be neither under-trained nor trained to the point of staleness.

Before mind and body have become jaded with the day's work is the best time for rehearsal. Fifteen minutes in the fresh of the morning are worth an hour of listless labor at night. Never continue rehearsals up to within an hour or two of delivery; at that late moment you can add nothing of value to your degree of preparedness - you are pretty certain to detract therefrom.

If possible, some of the rehearsals should take place in the auditorium in which the discourse is to be de. livered. But at all events private "vehement reflection" upon your subject, in which you rehearse it without uttering a word aloud, is a most valuable form of drill. 


\section{The Will in Rehearsal}

It is of prime importance that the will should dominate in rehearsal. Are you weary, has your production lost interest for you, are you torpid - what difference? The youth of to-day is entirely too susceptible to the state of his feelings in relation to the performance of duty. Just as little as a soldier would think of giving over drill for some slight cause, so little must you permit trifling matters to interfere with rehearsal. If your drills are conducted in the presence of an instructor, he may be suffering ten times the weariness and lack of interest in the theme which afflict you, yet at the call of duty he will arouse his energies to put life into his teaching. And you can do so as well. Compel yourself to put snap and alertness into your work. "I don't feel like it" should no more be taken as an excuse for indifferent performance in the rehearsal of a speech than in business, football, or any other matter requiring vim and ardor. He who wills to do his best at every rehearsal, speaking always with his audience in fancy before him; who trains his faculties to respond to the spur of his resolution; who strives to be as conscientious in delivery before a single critic as he would be in the presence of a multitude, - he may be depended upon in delivery to excel his best effort during rehearsal. Many an orator is said to "rise to the occasion," when he has simply prepared carefully. 


\section{Criticism during Rehearsal}

Burns sang of a universal need in his familiar lines :-

" $\mathrm{O}$, wad some power the giftie gie us

To see oursels as others see us !

It wad frae monie a blunder free us,

And foolish notion:

What airs in dress an' gait wad lea'e us,

And e'en devotion." 1

Now the public speaker may be quite sure that others will both see and criticise him; but he may be equally sure that sharp criticism during rehearsal will lessen adverse comment after delivery. Do not be hypersensitive. "The strength of criticism," says Longfellow, "lies only in the weakness of the thing criticised." Let the orator learn to turn even unjust criticism to account - it may at least teach him humility.

Cicero once asked a friend to write him what opinion Julius Cæsar had expressed of Cicero's verses, and requested a frank answer, "for," said the orator, "whatever he says, I should not think a hair the less of myself."

How different this from the spirit of Plato, who, when he was told that even the boys in the streets were laughing at his singing, replied, "Aye, then I must learn to sing better."

Criticism during rehearsal may come from three 
sources: from an instructor, who will speak for himself ; from a friend, who is less likely to speak his mind freely; from the orator himself, who is prone to be either too biased or too severe a critic. Yet selfcriticism is often the orator's only resort, his best friend. Emerson said that we need some one to make us do what we can. The orator must often perform this service for himself. Happy is he whose mind is so sensitive that it serves as a sort of triplicate mirror in which he views his own oratorical efforts. Therein he will study himself as calmly, as impartially, and with as little morbid sensitiveness as he would the delivery and the deliverances of another. His mental alertness will make him to perceive faults which his eye cannot see, and to feel the propriety of an expression or of a movement without the aid of any other critic.

One great danger is that the critic of self will become hypercritical. When once this faculty is aroused, it easily degenerates into morbidness, unless held in the grip of common sense. Audiences are neither perfect critics nor of an extraordinary average culture, therefore be moderate in self-judgment. It will not do to treat yourself as Thackeray treated the public. "The tinker thinks every pot is unsound. The cobbler doubts the stability of every shoe. So at last it grew to be the case with Thackeray. ... Keenness became so aggravated by the intenseness of his search that the slightest speck of dust became to his eyes as a foul stain." "St. Michael would have carried his armor amiss, and 
St. Cecilia have been snobbish as she twanged her harp." 1

The attitude of wise self-criticism is based upon knowledge ; it is upset by self-conceit ; it is distorted by oversensitiveness. The knowledge of a thousand rules cannot be actively present in the mind during either preparation or delivery, but these same rules, once mastered, become unified in the mind into a standard of excellence. Now it is the function of self-criticism to measure self, and the products of self, by this standard. In other words, the canons of logic, rhetoric, and elocution must cease to be mere canons and become an attitude of mind. Then, when the critic of self judges his own productions, he will do so without conscious reference to rules.

Of course, it is too much to expect that an inexperienced orator should have brought the art of self-valuation to this degree of perfection. Therefore, until the hour of such attainment, it may be well for him to apply to the discourse and to its delivery the tests suggested throughout this treatise.

${ }^{1}$ Life of Thackeray, Trollope, Chap. II. 



\section{PART IV}

\section{DELIVERY}


For an orator delivery is everything. - GoETHE.

Tact is not a sixth sense, but it is the life of all the five. It is the open eye, the quick ear, the judging taste, the keen smell, and the lively touch; it is the interpreter of all riddles, the surmounter of all difficulties, the remover of all obstacles.

Talent is power, tact is skill; talent is weight, tact is momentum; talent knows what to do, tact knows how to do it. Tact makes no false steps; it hits the right nail on the head; it loses no time; it takes all hints ; and, by keeping its eye on the weathercock, is ready to take advantage of every wind that blows.

- Condensed from London Atlas. 


\section{PART IV \\ DELIVER Y}

The crown, the consummation, of the discourse is its delivery. Toward it all preparation looks, for it the audience waits, by it the speaker is judged. Whatever of stress has been laid upon previous chapters has been for the sake of bringing the discourse to a successful delivery. All the forces of the orator's life converge in his oratory. The logical acuteness with which he marshals the facts about his theme, the rhetorical facility with which he orders his language, the control to which he has attained in the use of his body as a single organ of expression, whatever richness of acquisition and experience are his, - these all are now incidents, the fact is the sending of his message home to his hearers. Inventive genius, materials, workmanship, completed gun, powder, marksmanship, yes, and ball itself, exist not more singly and really for the sake of sending that projectile to the enemy's vital point, than do all the instruments of public speech exist for the sake of its effective delivery. You cannot over-estimate this truth. The hour of delivery is the "supreme, inevitable hour" for the orator. It is this fact that makes lack of ade- 
quate preparation such an impertinence. And it is this that sends such thrills of indescribable joy through the orator's whole being when he has achieved a success it is like the mother forgetting her pangs for the joy of bringing a son into the world. 


\section{CHAPTER XIX}

\section{HELPS AND HINDRANCES IN THE AUDIENCE}

Eloquence is in the assembly, not merely in the speaker.

- William Pitt.

The orator speaks not only to his auditors, but for them as well. Therefore let him study them : to know what manner of men they are, where lies the way to their hearts, how the strongholds of their approval may best be taken, - in short, how to attract and hold them.

There is not an hour in all his preparation when the speaker dare lose sight of his audience. They must ever sit before him, with all their helping and hindering habits; so that, when at last he comes to face them, they shall not seem strangers, even though he has never seen a single man of them before.

Whom are you to talk to? Forecast the answer as fully as you can. There is much to be found out without actual contact with an audience. What is the nature of public assemblies? What characteristics of a successful speaker seem most to please or arouse his hearers? What themes are listened to with most eager interest? Do refined audiences respond to the same style of material and delivery as move assemblies of the com- 
mon people? What conditions and circumstances seem to affect the mood of an audience?

Audiences differ quite as widely as authors' themes, so why should the speaker think to handle the one without thought when he bestows such care upon the other? Some of the greatest platform successes have been made by this nice appreciation of what is due an audience, both in extemporaneous and in written effort; while many brilliant speakers have failed because of a misapprehension of the spirit of those whom they were addressing or about to address. It is a problem of adjusting means to ends, of knowing human nature, and of saying the right word at the right time.

Abraham Lincoln once said: "I always assume that my audiences are in many things wiser than I am, and I say the most sensible thing I can to them. I never found that they did not understand me."

This great man's biographers assert that he strove to establish an alliance with his hearers - he never talked at them, but with them. Most audiences are not unfriendly, but apathetic. They stand an immense amount of nonsense before they get up (with creaking boots) and impressively retire. Seldom do auditors speak out so frankly as did a little chap whom the author once knew. A tedious speaker had long been droning through a Sunday-school address, when the lad impatiently called out to the superintendent, "Oh pshaw, let's sing number thirty-six!" It served the speaker right. He should have suited his preparation to his audience. Pericles 
had so much respect for his hearers that before addressing them he prayed to the gods that he might utter no words unsuited to the auditors or to the occasion. Once he was heard to say to himself, "Remember, Pericles, that thou art going to speak to men born in the arms of liberty, to Greeks, to Athenians."

While a common-sense forecast will do much, it will not supply a want of tact when once the speaker stands upon the rostrum. Macaulay says, "There is a certain tact, resembling an instinct, which is often wanting in great orators and philosophers." This statement is too strong. Rarely does an orator become great without a large natural endowment of tact, greatly strengthened, no doubt, by a varied experience with the vagaries of public assemblies. Occasionally such embarrassing circumstances may confront a speaker as to leave him no leg to stand on, if his tact does not come to the rescue. He may have resolved never to "rub the face of an audience the wrong way," but causes beyond his control sometimes knock his best-laid plans into chaos.

During the Civil War, Henry Ward Beecher handled a turbulent audience in Liverpool with consummate skill and tact. The many sympathizers with secession raised such an uproar that he could scarcely proceed. See how in his introduction he met the exigency:-

"Now, personally, it is a matter of very little consequence to me whether I speak here to-night or not. [Laughter and cheers.] But, one thing is very certain, if you do permit me to speak here to-night, you will 
hear very plain talking. [Applause and hisses.] You will find a man - [interruption] - you will not find me a man that dared to speak about Great Britain three thousand miles off, and then is afraid to speak to Great Britain when he stands on her shores. [Immense applause and hisses.] And if I do not mistake the tone and temper of Englishmen, they had rather have a man who opposes them in a manly way - [applause from all parts of the hall] — than a sneak that agrees with them in an unmanly way. [Applause and 'Bravo!'] Now, if I can carry you with me by sound convictions, I shall be immensely glad - [applause]; but if I cannot carry you with me by facts and sound arguments, I do not wish you to go with me at all; and all that I ask is simply FaIr Play. [Applause, and a voice: 'You shall have it, too.']"

In his epigrammatic style Nathan Sheppard says: "It is always pleasant to speak to a Scotch audience. They always understand you. If you have a point they see it, and if you have not a point they see that." Scotch audiences are not singular in possessing that discerning characteristic. The American audience is keenly alive to a good point, - though not very free in demonstrating its satisfaction, - and equally quick to rebuke the first sign of trickery, cajolery, or lack - of frankness in a speaker, by an ominous withdrawal of its sympathies.

Professor Phelps so far confirms Macaulay's remarks on the lack of tact in great orators, as to relate of 
Patrick Henry that once he thought to win the favor of the backwoodsmen of Virginia by thus imitating their colloquial dialect: "All the larnin upon the yairth are not to be compared with naiteral pairts." But his sagacious hearers knew that he knew better, and resented the imputation that they did not.

There is no finer opportunity for the display of tact than in the introduction of wit and humor into a discourse. Wit is keen and like a rapier, piercing deeply, sometimes even to the heart. Humor is good-natured, and does not wound. Wit is founded upon the sudden discovery of an unsuspected relation existing between two ideas. Humor deals with things out of relation, with the incongruous. It was wit in Douglass Jerrold thus to retort upon the scowl of a stranger whose shoulder he had familiarly slapped, mistaking him for a friend: "I beg your pardon, I thought I knew youbut I'm glad I don't." It was humor in a Southern orator to liken the pleasure of spending an evening with a Puritan girl to that of sitting on a block of ice in winter, cracking hailstones between his teeth.

Times without number a witty retort or, better still, a brief humorous illustration has tided the speaker over a critical period of embarrassment and impending failure. Whether tact may be acquired by those who utterly lack it is a question by no means germane to this treatise. But since alertness of mind and self-possession are its marked characteristics, it certainly may be strengthened by observation and experience. 


\section{CHAPTER XX}

FACING THE AUDIENCE

The effective public speaker receives from his audience in vapor what he pours back on them in a flood.-GLAdstone.

Public speakers of long experience have said that they never face an audience without undergoing that painful discomposure called stage fright.

\section{Just before Speaking}

is a critical moment. Scores of methods for inducing repose of mind and body have been suggested, but beyond the ideas touched upon in Chapter XV, Section 2, of this volume (which see), only one word of advice will be attempted: Maintain your confidence. If you have made faithful, intelligent preparation, you know more of your phase of the subject than any one in your audience is likely to know. If you are speaking from a sense of duty, go forward as to a duty. If you have committed all or part of the address to memory (and committing to memory means handing a thing over to the memory), you must not bear the burden too heavily upon your spirit. Be confident by a supreme effort of the will. Be confident because of reliance upon pre- 
paratory effort, upon the teachings of experience, upon the good sense of your audience, upon your ability to hold yourself in hand. This is not advising presumption. Far from it. It is simply urging the importance of asserting your nerve as determinedly before speaking as you would before going to the dentist. No better advice than the foregoing could apply also to

\section{The First Moments of Delivery}

An audience yields everything to a firm and confident speaker. Even when you are quaking in your boots with the ague of fear, and your teeth fain would beat "retreat," you must assume a boldness you do not feel. For doing this there is nothing like deep, steady breathing, a firm look at the dreaded audience, and - if you are not-caught at it - a clenched fist. But do not fear your auditors. They want you to succeed, and always honor an exhibition of pluck. They are fair, and know that you are only one man against a thousand. In these climes audiences do not eat the pre-prandial orator after hearing his discourse. Besides, if you are half so bad as at that moment you feel yourself to be, you are not good enough to eat. Look at your audience, squarely, earnestly, expressively. Why do so many men denounce big hats if they do not wish to catch the eloquent gleam of the orator's eye? The habit of looking at the walls or the ceiling during delivery robs the orator of much of his power. Mirabeau used to transfix his auditors by the intensity of his gaze, and though he crossed their 
dearest purposes, they dared not lift a finger in opposition to the flood of his eloquence.

Will to be self-controlled if you cannot be calm. The audience is not whirling madly in a circle, there are only the usual number of lights, the rostrum is not heaving, Niagara is not roaring beside you. No! Put these phantasms down by will-power. No one who has not experienced it can imagine the terrors of stage fright; but no one who has not cultivated it can understand the power of the human will.

The true nature of the introductory sentences has been dwelt upon in a previous chapter. ${ }^{1}$ A firm grip upon the opening words is necessary, so that you could repeat them even if the roof should collapse. Begin at a moderate pitch, in a moderate tone, and do not let yourself get too fiery in the introduction. You will need some of that fire in five minutes. This much of Dr. Leifchild's rule is good :-

Begin low,

Go on slow;

Rise higher,

And take fire.

It is related of the second Henry Grattan that he " could not utter a half-dozen sentences without getting into such a passion and indulging in such violence of gesture that it was quite unsafe for any member to sit within reach of his right arm."

${ }^{1}$ See pp. $76-78$. 


\section{The Course of Delivery}

Excess of feeling at the outstart must be checked, not choked. It is just as offensive for a speaker to go to sleep on his feet, as for him to rant. Indeed, ranting is the lesser of the two evils. The same vital power of will which keeps emotion within bounds will serve to call it forth when needed. It is not necessary to argue the psychological question of whether emotion can be made, nor is it needful to study the actor's tricks in simulating emotion; it is sufficient to know that you can arouse yourself from torpor on the platform, that you can get into sympathy with your theme, that you can make yourself feel anything on which you think intently enough, from a creeping chill to hot indignation. Just now, while you are reading, you can taste the sour of acid on the tip of your tongue, feel an itching on your left shoulder-blade, or a tickling in your throat - if you will to do so.

This excitation of the emotions for oratorical purposes may be cultivated. Artificiality! sneers some one. Trickery! complains another. "Stale indignation, and fervor a week old!" laughs Sidney Smith. All wrong. It is physical earnestness. It is a legitimate calling upon the body to be what it was created to be: the instrument of the soul, responsive to its moods and tenses. "He who reigns within himself and rules his passions, desires, and fears, is more than a king." $1 \mathrm{He}$ 
is an orator. You would not think of condoling with a bereaved friend in a harsh, unfeeling tone. Even if you had a headache or were pre-occupied, you would command the delicately sympathetic word and tone. This is not hypocrisy, it is common decency. And so in public speech you must be so responsive to your thought that emotion will arise when needed. Take your message to heart - you can if you have prepared with sincerity and conviction. Make the cause for emotion in your discourse a personal cause, and it will call forth your own emotions.

Never think for a moment that effective oratory can be an accident. Certainly the inspiration of delivery will often carry the orator beyond himself, and give his discourse a sweep and power as unpremeditated as it is convincing. But just as certainly such eloquence could not be attained had the orator failed to call into play notice, call into play - all his powers of body, mind, and spirit. Holyoake relates of Shiel, the little Irish orator, that when he replied in the House of Commons to the Duke of Wellington, who had said that the Irish were aliens in race, blood, and religion, "his accents were in his hair, his eyes, in his arms, in every limb. He was alive all over, and from this confluence of action proceeded a piercing stream of sentences of scorn and fire." 1

The annals of oratory abound in instances of great speakers who made the most of their physical endowment, and of many who, by sheer force of determination, 
won in spite of the handicap of diminutive body, squeaking voice, lisping tongue, or sluggish blood.

How do you clench your hand for a fist gesture - so weakly that it would not hurt a child? Or do you throw your whole muscular organization into that clenched fist? How do you set your teeth in speaking of determination? Does your eye fade or flash when you press home your point? Does your voice ring or falter in direct appeal? Naturalness, ease, dignity, variety, elasticity, quickness, - these are the expressions of a body vitalized and made responsive to the inner man.

What is true of physical earnestness is true of manner in delivery. Does the thought require the familiarity of colloquial expression, the directness of appeal, the dignity of elevated mood, or the fervor of passion? Then rely upon the will in delivery. Are you, like Sir Henry Irving and uncounted others, the victim of offensive mannerisms? Simply stop them by thinking and willing. Do not lose the kind offices of so good a friend as your will by lack of acquaintance with its power to do you good.

No more wise advice regarding delivery was ever given public speaker than that offered by Hamlet to the players.

"Nor do not saw the air too much with your hand, thus ; but use all gently ; for in the very torrent, tempest, and (as I may say) whirlwind of your passion, you must acquire and beget a temperance, that may give it smoothness. $\mathrm{O}$, it offends me to the soul, to hear a robustious 
periwig-pated fellow tear a passion to tatters, to very rags, to split the ears of the groundlings $;^{1}$ who, for the most part, are capable of nothing but inexplicable dumb show, and noise. I would have such a fellow whipped for o'er-doing Termagant; it out-herods Herod. Pray you avoid it.

"Be not too tame, neither, but let your discretion be your tutor: suit the action to the word, the word to the action; with this special observance, that you o'erstep not the modesty of nature; for anything so overdone is from the purpose of playing, whose end, both at the first, and now, was, and is, to hold, as 'twere, the mirror up to Nature, to show Virtue her own feature, Scorn her own image, and the very age and body of the time his form and pressure. Now, this overdone, or come tardy off, though it make the unskillful laugh, cannot but make the judicious grieve; the censure of the which one must, in your allowance, o'erweigh a whole theater of others. Oh, there be players that I have seen play and heard others praise, and that highly - not to speak it profanely, that, neither having the accent of Christians, nor the gait of Christian, pagan, or man, have so strutted and bellowed that I have thought some of Nature's journeymen had made men, and not made them well, they imitated humanity so abominably." 2

\section{Ending the Discourse}

The thoughts and examples presented in section 4 of Chapter XI. will be of value here. The peroration must

${ }^{1}$ Auditors on the ground floor.

2 Hamlet, Act III. Scene 2. 
fittingly end the discourse. Happy are you if it shall be said of you, in the words of "rare Ben Jonson," "The fear of every man that heard him was lest he should make an end." How often is the fear quite of an opposite sort. Few speakers discern that length does not indicate depth. Better stop before you are through than go on after you have finished. Only makers of short speeches are invited to speak again. We have all heard speakers who were manifestly in the predicament of the lad who, having unwisely grabbed a dog by the tail, was afraid of the consequences should he relax his grip, so he called out to his comrades, "Some one o' youse fellers come out here and help me let go!"

Uncommon sense will be found the best teacher in all such difficulties.

Matthew Arnold, in many aspects of his mind a modern Greek, used to emphasize the Greek idea of unity of effect. He complained that many writers were so engrossed with perfecting the sentence, the figure of speech, the detached idea, that they lost out of their sight the object of leaving upon the mind a single, compact effect of the whole. Quite the same is true of orators. If the progress of the discourse has in any wise failed - oh, sad failure!-to keep clearly before the auditor the grand movement of thought, by no means neglect leaving in the conclusion a final compact impression by summary and enforced teaching. 


\section{CHAPTER XXI}

DO'S AND DON'T'S FOR DISCOURSE-HINTS FOR SELFCRITICISM

To thine own self be true.

- Shakespeare, Hamlet, Act I. Scene 3.

Speak with such simplicity that your humblest auditor must understand you. Winston Churchill declares in The Crisis: "The importance of plain talk can't be overestimated. Any thought, however abstruse, can be put in speech that a boy or negro can grasp."

Be explicit; speak things that mean something, and mean them when you speak.

Be brief. Pope wrote of his great master :-

"E'en copious Dryden wanted or forgot

The last and greatest art, the art to blot."

- Essay on Criticism.

If you are in doubt as to the clearness of a thought, write it out and read it to the hired girl.

If you would convince your hearers, pin them down to your view of the question. 
Don't leave the highway of your thought to chase a butterfly, be it never so beautiful. Macaulay said of Burke that he "almost always deserted his subject before he was abandoned by his audience."

Henry Ward Beecher said that "The secret of eloquence is truth."

If you would be eloquent, study the tastes of your hearers. To Juliet,

$$
\text { "Every tongue that speaks }
$$

But Romeo's name, speaks heavenly eloquence."

- Romeo and Juliet, Act III. Scene 2.

Don't be carried away by applause, it is "the spur of able minds, and the aim of weak ones."

Don't be disconcerted if an American audience is cold. With Theseus confidently say :-

"Out of this silence, yet, I pick'd a welcome."

- Midsummer Night's Dream, Act V. Scene I.

When the object of your discourse is emotional, use different means to attain it than when your object is intellectual.

Don't arouse an emotion - either in yourself or in your auditors - which you are unable to direct.

Don't mistake bathos for pathos.

To stand erect, grasp your scalp lock and pull straight up, drawing your chin in. 
Don't bow as though you had hinges in your neck.

Look in the direction of a locative gesture, but not in the direction of a gesture for emphasiṣ.

Don't let your voice become inaudible toward the close of a word or of a sentence.

Nathan Sheppard gives this advice for the care of the throat: "If you awake in the night and find your mouth open, get up and shut it."

Don't seek after novelty. Carlyle says :-

"The merit of originality is not novelty, it is sincerity."

- The Hero as a Priest.

Don't permit the skeleton of your address to parade its bones. Clothe it with flesh so vital that it would bleed at the prick of a needle.

Don't think that any amount of talent can atone for habitual lack of preparation. Milton conceived Paradise Lost at thirty-two, but did not compose it until he had added, by twenty years of further preparation, to his already well-stored mind.

In $A$ Summer Hymnal, John Trotwood Moore says : "If brain-workers would only do like cows, - gather up their material as they walk around in the fields and woods and assimilate it while resting, - they would have more brains."

Learn to think in good English and practice your vocabulary in conversation. 
Rarely permit yourself to indulge in impromptu speech. Lowell makes one of his characters say :-

"I made the follerin' observation

Extrump'ry, like most other tri'ls o' patience."

- Biglow Papers.

Don't wait to dive for pearls of thought until you mount the platform. It might be painful to the audience.

Don't write too soon after getting a new thought; let it work.

Thomas Wentworth Higginson thus advises speakers: "Plan for one good fact and one good illustration under each head of your subject."

Don't be afraid to apologize if you must.

Shenstone compared long sentences in a short address to large rooms in a small house.

Don't let your words be bigger than your ideas.

Don't let your personality overtop the importance of your subject. 


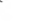

t

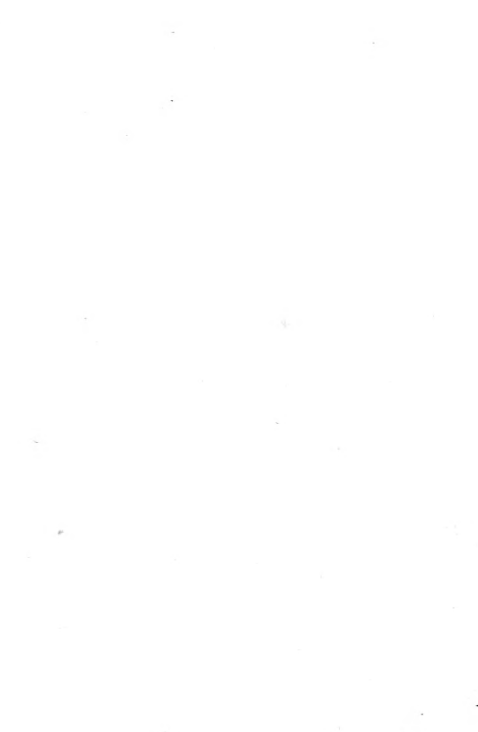

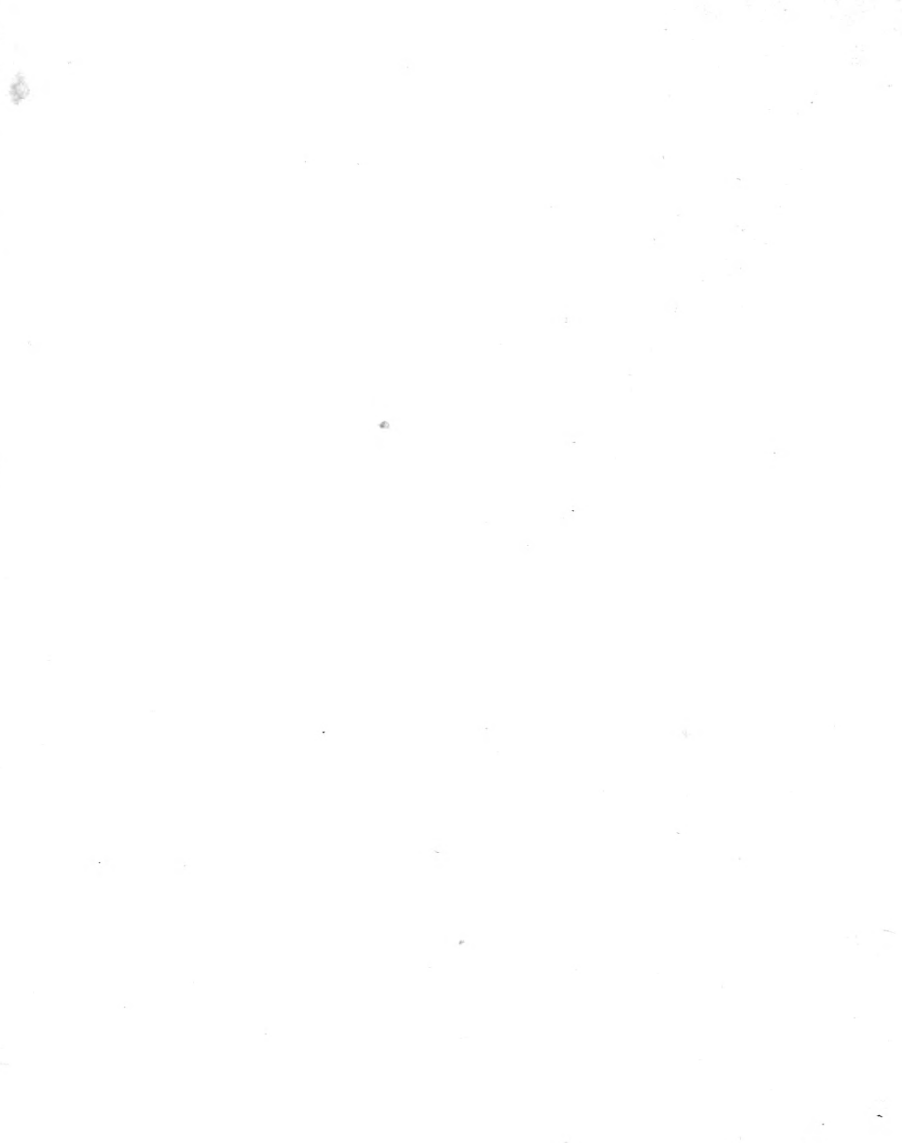
. . . . (.) 
APPENDICES 
I succeeded in Parliament by resolving to succeed.

- Lord Chesterfield.

Sweat of the brow, and up from that to sweat of the brain; sweat of the heart, up to that "agony of bloody sweat," which all men have called divine! Oh, brother, ... this is the noblest thing yet discovered under God's sky. - Thomas Carlyle.

The longer I live, the more I am certain that the great difference between men - between the feeble and the powerful, the great and the insignificant - is energy, invincible determination, a purpose once fixed, and then, death or victory! That quality will do anything that can be done in this world; and no talents, no circumstances, no opportunities, will make a two-legged creature a man without it. - SIR Fowell BUXTON. 


\section{APPENDICES}

\section{THE STUDY OF ORATORICAL MODELS}

WHATEVER is valuable in oratorical theory has been arrived at by observing the lives, characters, and methods of successful orators. Hence it is evident that a critical examination of famous orations must be of unusual service to all who aspire to attract and hold audiences. It is far more important for the orator to determine by what means great speakers have overcome difficulties and commanded "the applause of listening Senates," than it is to make up a list of fancied characteristics which "the ideal orator" possesses. The problem may be quite simply stated, if not easily answered: What lessons from the practice of great orators may I learn and apply to my own case?

The method of study suggested is that of analysis. In examining oratorical models attention should be given to the following lines of inquiry :-

\section{Biography.}

I. Natural talents and natural defects.

2. Facts in the orator's life that tended to make him a great speaker. 


\section{ORations.}

I. Circumstances of delivery.

2. Object of the speaker.

3. General style of the discourse.

4. Logical structure.

5. Rhetorical structure.

6. Comparison with orations of other speakers.

To assist in the study of oratorical models, Appendix $A$ and Appendix B have been prepared. The practice of analyzing the structure of notable discourses will yield large returns to the student, especially an increased facility in constructing his own oration framework. The outlines ${ }^{1}$ presented in Appendix A may serve as models, either for analysis or for constructive work. Attention is called to the discussions found in Chapters IX., X., and XI. of this treatise.

It is not necessary to include in these pages biographical material regarding orators - that is to be found in any complete encyclopedia, and well deserves careful study; but in Appendix B there are given a number of great orations, upon a diversity of themes, of varied kinds, and by well-known speakers. In most instances the orations have been abbreviated so as to present only such parts as are most characteristic of the orator and most worthy of careful study. They may also be used for public declamations.

${ }^{1}$ For a full discussion of the brief and the outline, refer to Principles of Argumentation, Baker. 


\section{APPENDIX A}

\section{MODEL ORATION OUTLINES}

\section{I}

PERICLES' FUNERAL ORATION OVER THE ATHENIAN DEAD, ${ }^{1} 43 \circ$ B.C.

I. Introduction.

Words are inadequate to sound the praises of the brave.

II. The Sources of Athenian Greatness.

I. The deeds of noble ancestors who brought Athens to freedom and power.

2. The admirable form of the Athenian government.

3. The refinements of her life.

4. Her superiority in war.

5. The public spirit of her citizens.

6. In brief : Athens is the mother of Hellas.

III. Eulogy of the Fallen Heroes.

I. The praise of Athens reflects upon her dead.

2. "Death is the final seal of their virtues and secures them from all change of fortune."

1 This oration, reported by Thucydides, the Greek historian, was commemorative of the Athenian heroes who had fallen during the first year of the Peloponnesian War. 
3. Their praises have extended to the whole earth, and Athens holds their example as a precious heritage.

IV. Consolations for their Kindred.

I. Parents.

2. Sons, brothers, and widows.

V. Conclusion.

"Athens crowns her sons" by honorably interring them and rearing their children "at the public charge."

\section{II}

ORATION OF ÆSCHINES AGAINST CTESIPHON, 33I B.C.

I. INTRODUCTION.

Existence of factions in the state; these lead to illegal proceedings; the factions must be stopped.

II. The Proceedings of Ctesiphon as to DemosTHENES WERE ILlEgal.

I. Because the law forbids a magistrate to be crowned before the accounts of his office have been accepted.

2. The fact that Demosthenes has expended his own money in the public service does not exempt him from the law.

3. Demosthenes held two offices at the time Ctesiphon proposed to crown him.

4. Ctesiphon proposed the coronation in an illegal place. 
III. Demosthenes did not Deserve this Honor, BECAUSE OF -

I. His private character.

2. His public character.

IV. Greater Strictness Should be observed in conferring Public Honors.

V. Eschines compares himself with DemostheNES.

VI. He Reaffirms the Illegality of the Decree AND THE Unworthiness OF Demosthenes.

VII. He cautions the Judges not to BE Sivayed By the Eloquence of Demosthenes, NOR BY FRIENDSHIP FOR HIM.

VIII. Conclusion.

\section{III}

DEMOSTHENES ON THE CROWN, ${ }^{1} 33$ B.C.

I. InTRODUCTION.

I. Demosthenes appeals to the gods.

2. He asserts his right to follow his own order of defense (which Æschines had opposed).

II. He Refutes the Accusations foreign to the INDICTMENT.

I. He declines to consider the charges against his private life, but permits the judges, who know him, to decide upon their validity.

1 This oration is a reply to the accusations made against Demosthenes in Aschines' oration against Ctesiphon. 
2. He dismisses the (foreign) charges as to his public life by referring to their evident falsity and malicious intent.

III. He Refutes the Accusations found in the INDICTMENT.

I. He reviews his public life and measures. (Under nine heads he discusses his relations with Philip of Macedon, the course he - Demosthenes - had urged upon Athens, and various other public measures.)

2. He maintains the legality of Ctesiphon's proposal to crown him.

(a) He was not responsible for his accounts.

(b) This had been acknowledged by Æschines.

(c) The place named was in accordance with the law.

IV. He compares the Character and Policy of Æschines WITH hIS OWN.

I. The character of Æschines.

2. The policy of Æschines.

3. Demosthenes' policy.

4. Further comparisons between himself and Æschines.

5. His answer to the warning of $Æ s c h i n e s$ as to Demosthenes' oratory.

6. Final reasons for being crowned.

(a) Because he had never taken bribes.

(b) Because of his policy.

(c) Because of his patriotism.

V. Conclusion. 


\section{[David Hume says of Demosthenes :-}

"His style is rapid harmony exactly adjusted to the sense; it is vehement reasoning, without any appearance of art; it is disdain, anger, boldness, freedom, involved in a continuous argument; and of all human productions the orations of Demosthenes present to us the models which approach the nearest to perfection."]

\section{IV}

WASHINGTON'S CONTRIBUTION TO NATIONALITY ${ }^{1}$

I. His Personality was Preëminent.

I. In molding the plastic elements of the country.

(a) The survivors of his army.

(b) The commercial and creditor classes.

2. Over contemporary statesmen.
(a) Hamilton.
(b) Jefferson.

II. His Statesmanship encouraged the Spirit of Nationality.

I. By pacifying angry political factions.

(a) In his cabinet.

(b) Between the English and the French parties.

2. By his foreign policy of neutrality.

(a) As in England's quarrel with France.

(b) Favoring Jay's treaty.

3. By arousing respect for his domestic policy.

(a) Respect for the new forms of government.

(b) Respect for public credit and for law.

4. By his devotion to the Union.

${ }^{1}$ Condensed from Composition-Rhetoric, Scott and Denney, pp. 274, 275. 


\section{V}

FOREIGN IMMIGRATION SHOULD BE RESTRICTED ${ }^{1}$

(Note the variation of cause and effect.)

I. FACt as CAUSE: Many immigrants are paupers. (A paragraph of proofs involving statistics or statements of authorities on this point.)

II. Fact as Effect: They fill our alms-houses and become a public charge. (A paragraph of proofs involving statistics or statements of authorities.)

III. Fact as Cause: Some of them are criminals.

$(\mathrm{A}$ paragraph of proofs.)

IV. Fact AS EFfect: They reënforce the criminal classes. (A paragraph of proofs.)

V. Fact as Cause: Many of them know nothing of the duties of free citizenship. (A paragraph of. proofs.)

VI. Fact as Effect: Such immigrants recruit the worst element in our politics. (A paragraph of proofs.)

\section{VI}

RAILROADS ARE A UNIVERSAL BENEFIT

I. They promote Material Prosperity :

I. By promoting commercial prosperity -

(a) For they facilitate exchanges,

(b) And help labor to migrate.

1 Composition-Rhetoric, Scott and Denney, p. 241. 
2. By promoting physical prosperity -
(a) For they raise the standard of living,
(b) And furnish labor to the poor,
(c) And render wars improbable.

II. They promote Social Prosperity:

I. By promoting intelligence -

(a) For they carry reading matter,

(b) And save time for reading,

(c) And encourage travel.

2. By promoting morals -

(a) For they arrest crime,

(b) And make men more broad-minded.

\section{VII}

\section{ATTENTION}

I. INTRODUCTION.

Attention indispensable to the performance of any great work.

II. Defined and Illustrated.

I. From common observation.

2. From the lives of great men.

III. Its Relation to other Mental Powers.

I. Reason.

2. Will.

3. Imagination.

4. Memory. 
IV. Attention may be cultivated.

I. Involuntary attention.

2. Voluntary attention.

V. Conclusion.

The consequences of inattention and of attention.

\section{VIII}

THE NORSE DISCOVERY OF AMERICA ${ }^{1}$

I. The Norse Medikeval Historians state that about IOOO A.D. Certain Norse Sailors FOUND, TO THE SOUTHWEST OF GREENLAND, A Land which they called Vineland. This Account is worthy of Credence, Because-

I. It is given as history, not as fiction. If the account had been imaginative, the narrators would probably have peopled the land with dragons, unicorns, and similar marvels; instead of which they refer throughout to objects and incidents which indicate observation rather than fancy.

2. It is related or referred to in many Norse books of history, dating from 900 years ago down to the present.

${ }^{1}$ The reasoning is taken from Discovery of America, Fiske, Vol. I. pp. 148-226; and the brief follows that found in Elements of Rhetoric and English Composition, Carpenter, pp. 114-115. 
II. IT IS NOT UnNatural that the NoRthmen SHOULD HAVE DISCOVERED THE COAST OF North America, Because -

I. They were of a roving disposition, good seamen, and had vessels capable of taking long voyages, as is shown by
(a) Their voyages to Constantinople and the White Sea, etc.,
(b) By the fact that they had settled in Ice- land, and
(c) That they had settled in Greenland and explored Baffin Bay.

2. The settlers in Greenland had a motive in exploring for and visiting new coasts, for the sake of
(a) Wood, which was scarce in Greenland and Iceland, and which they needed for shipbuilding; and

(b) Barter with the natives.

3. The relative position of the northeastern coast of North America is such that ships could easily be driven there from the vicinity of Greenland by northeast gales and currents.

III. The Accounts given of Vineland obviously refer to the North American Coast, BECAUSE -

I. Vineland was said to be southwest of Greenland, and 
2. The statements regarding the character of the coast, the vegetation, animals, and inhabitants could apply only to the American coast, for the narrative speaks of
(a) Shorter days.
(b) Corn.
(c) Grapes.
(d) Inhabitants corresponding accurately to the Indians.

IV. Conclusion.

We are justified in believing in the Norse discovery of America.

\section{IX}

\section{HOW PROSPERITY CAME ${ }^{1}$}

The country ripe for prosperity. - Great wheat crop in 1897. - Importance of the farmer bringing good times. - Effect of the Spanish-American War on the new prosperity. - Fortuitous circumstances that assisted. - Increased gold production and its results. - Comparison of stores of gold in the United States with those in Europe. - Extraordinary increase in per capita circulation.-Compared with great foreign nations. - Concluding reflections.

1 This is a summary of the contents of Chapter II., Our New Prosperity, Ray S. Baker. 


\section{$\mathrm{X}$}

\section{A NATION OF CITIES 1}

I. Remarkable Growth of Cities in the United States during Last Quarter Century.

This is due to

I. The application of scientific methods, and of machinery, to agriculture. This drives many men from the farms, because

(a) There is a natural limit to the demand for farm products.

(b) Wages would fall below the living point were all the laborers to remain, since

- fewer men can now do an increased amount of work.

(c) Many men can find employment on the farms at only the harvest season.

2. The substitution of mechanical for muscular power in manufactures draws many laborers to the cities.
(a) Labor is made lighter.
(b) Women and children find employment.
(c) Unskilled laborers earn more than they could by mere manual labor.

3. The railway has made the city easily accessible
(a) To those seeking employment,
(b) To buyers, and
(c) This gives employment to more producers and sellers.

1 Suggested by Chapter II., The Twentieth Century City, Strong. 
4. The life of the city is attractive to those bred in the country, and affords opportunities for advancement.

II. This Remarkable Growth gives rise to Grave PROBLEMS.

(Here the brief might be indefinitely expanded by a discussion of the various problems.)

I. Our country has shown a masterful spirit in solving great problems as they have arisen.

2. We may confidently expect that these religious, economic, and political problems will likewise be satisfactorily solved.

\section{$\mathrm{XI}$}

THE UNITED STATES A CHRISTIAN NATION

I. Introduction: Why the subject is timely. Influences operative against this position.

II. Consider the Fact that Christianity PResided over the Early History of America.

I. First practical discovery by a Christian explorer. Columbus worshiped God on the new soil.

2. The Huguenot.

3. The Cavalier.

4. The Puritan.

III. The Birth of our Nation was under Christian Auspices.

I. Christian character of Washington.

2. Other Christian patriots. 
IV. Our Later History has only emphasized THIS FACT.

V. Our Governmental Forms and many of our Laws ARE OF a Christian Temper.

I. The use of the Bible in public ways.

2. The Bible in our public schools.

3. Christian chaplains minister to our law-making bodies, to our army, and to our navy.

4. The Christian Sabbath is officially and generally recognized.

5. The Christian family and the Christian system of morality are at the basis of our laws.

VI. The Life of the People testifies of the POWER OF Christianity.

VII. Other Nations Regard Us AS A Christian People.

VIII. Conclusion: The attitude which may reasonably be expected of all good citizens toward questions touching the preservation of our standing as a Christian nation.

\section{XII}

\section{MANHOOD AND MONEY}

Money does not make the man. - Not all men accept this statement as true. - Manhood is worth millions, for it is constantly in demand.-Positions which nothing but manhood can fill. - Manhood often tested by the power of money. - Examples. - False ideals held by too many 
with regard to money-making. - Manhood and moneymaking not necessarily incompatible. - Money will pass, but manhood never. - The universal cry, in all departments of life, is: Wanted - a man!

\section{XIII}

LOT'S ESCAPE ${ }^{1}$

I. An Alarm, "Escape for thy life."

II. A Caution, "Look not behind thee."

III. An Exhortation, "Escape to the mountain."

\section{XIV}

A BLESSED PARADOX: AN EASY YOKE AND A LIGHT BURDEN ${ }^{2}$

I. A Service of Love.

II. An Assisted Service.

III. A Service along God's Path.

IV. A Service of Hope.

\section{XV}

THE POWER OF THE GOSPEL ${ }^{3}$

I. It is An Informing Power.

For it brings knowledge of momentous questions to the individual, and spreads enlightenment to the whole earth.

${ }^{1}$ A sermon from Genesis xix. I7.

2 A sermon from Matthew xi. 30 .

${ }^{3}$ A sermon from I Thessalonians i. 5. 
II It is a Reforming Power.

For it has formed anew the methods of thought, government, and life wherever it has been preached.

III. It is a Transforming Power.

For it transforms the human heart from a well of evil to a spring of sweetness and purity.

IV. It is a Deforming Power.

For its enlightening influence is destructive of superstition, untruth, and evil.

V. It is A Conforming Power.

For its end is the conforming of the believer to the image of Christ. 


\section{APPENDIX B}

\section{MODEL ORATIONS}

Most of the following orations have been prefaced with brief analyses, for the purpose of indicating the general structure of the thought. In no case, however, is the outline so full as to make more minute analysis unprofitable. Indeed, no two students are likely to analyze an oration in just the same way. Several of the discourses have been presented entirely free of suggestive outline.

\section{I}

\section{THE AMERICAN IDEA}

\section{By Daniel Webster (1782-1852)}

[The following selected passages are from a commemorative oration delivered June I7, I825, on the fiftieth anniversary of the battle of Bunker Hill. Upon this occasion the cornerstone of the monument was laid. So much of the oration as can here be given may be thus outlined: (I) The remarkable nature of the American Revolution. (2) The advanced civilization under which the orator and his hearers live. (3) Direct eulogy of the patriots who fought in the battle of Bunker Hill. (4) Great changes noted when the present occasion is compared with fifty years ago.]

The great event in the history of the continent, which we are now met here to commemorate, - that prodigy 
of modern times, at once the wonder and blessing of the world, - is the American Revolution. In a day of extraordinary prosperity and happiness, of high national honor, distinction, and power, we are brought together in this place by our love of country, by our admiration of exalted character, by our gratitude for signal service and patriotic devotion. ...

We live in a most extraordinary age. Events so various and so important that they might crowd and distinguish centuries, are in our times compressed within the compass of a single life. When has it happened that history has had so much to record, in the same term of years, as since the I 7 th of June, I775? Our own Revolution, which under other circumstances might itself have been expected to occasion a war of half a century, has been achieved; twenty-four sovereign and independent states erected; and a general government established over them, so safe, so wise, so free, so practical, that we might well wonder its establishment should have been accomplished so soon, were it not far the greater wonder that it should have been established at all.

We now stand here to enjoy all the blessings of our own condition and to look abroad to the brightened prospects of the world, while we still hold among us some of those who were active agents in the scenes of I775, and who are now here, from every quarter of New England, to visit once more, and under circumstances so affecting, - I had almost said overwhelming, - this renowned theatre of their courage and patriotism.

Venerable men! you have come down to us from a former generation. Heaven has bounteously length- 
ened out your lives, that you might behold this joyous day. You are now where you stood fifty years ago, this very hour, with your brothers and your neighbors, shoulder to shoulder, in the strife for your country. Behold, how altered! The same heavens are indeed over your heads; the same ocean rolls at your feet; but all else how changed! You hear now no roar of hostile cannon; you see no mixed volumes of smoke and flame rising from burning Charlestown. The ground strewed with the dead and the dying; the impetuous charge; the steady and successful repulse; the loud call to repeated assault; the summoning of all that is manly to repeated resistance; a thousand bosoms freely and fearlessly bared in an instant to whatever of terror there may be in war and death, - all these you have witnessed, but you witness them no more. All is peace. The heights of yonder metropolis, its towers and roofs, which you then saw filled with wives and children and countrymen in distress and terror, and looking with unutterable emotions for the issue of the combat, have presented you to-day with the sight of its whole happy population, come out to welcome and greet you with a universal jubilee. Yonder proud ships, by a felicity of position appropriately lying at the foot of this mount, and seeming fondly to cling around it, are not means of annoyance to you, but your country's own means of distinction and defense. All is peace : and God has granted you this sight of your country's happiness, ere you slumber in the grave. He has allowed you to behold and to partake the reward of your patriotic toils; and He has allowed us, your sons 
and countrymen, to meet you here, and in the name of the present generation, in the name of your country, in the name of liberty, to thank you!

\section{II}

\section{THE CHILDREN OF THE POOR}

By Theodore Parker (1810-1860)

[This descriptive excerpt was delivered as part of a public lecture in Boston. It contains three parts: (I) A description of the poor waifs. (2) An appeal for sympathy. (3) An argument for prison reform.]

If you could know the life of one of those poor lepers of Boston, you would wonder and weep. Let me take one of them at random out of the mass. He was born, unwelcome, amid wretchedness and want. His eoming increasedh. Miserably he struggles through his infancy, less tended than the lion's whelp. He becomes a boy. He is covered only with rags, and those squalid with long-accumulated filth. He wanders about your streets, too low even to seek employment, now snatching from a gutter half-rotten fruit which the owner flings away. He is ignorant; he has never entered a schoolhouse; to him even the alphabet is a mystery. He is young in years, yet old in misery. There is no hope in his face. He herds with others like himself, low, ragged, hungry, and idle. If misery loves company, he finds that satisfaction. Follow him to his home at night; he herds in a cellar; in the same sty with father, mother, brothers, sisters, and perhaps yet other families of like 
degree. What served him for dress by day is his only bed by night.

Well, this boy steals some trifle, a biscuit, a bit of rope, or a knife from a shop window. He is seized and carried to jail. The day comes for trial. $\mathrm{He}$ is marched through the streets in handcuffs, the companion of drunkards and thieves, thus deadening the little self-respect which Nature left even in an outcast's bosom. He sits there chained like a beast; a boy in irons! the sport and mockery of -men vulgar as the common sewer. His trial comes. Of course he is convicted. The show of his countenance is witness against him. His rags and dirt, his ignorance, his vagrant habits, his idleness, all testify against him. That face so young, and yet so impudent, so sly, so writ all over with embryo villainy, is evidence enough. The jury are soon convinced, for they see his temptations in his look, and surely know that in such a condition men will steal: yes, they themselves would steal. The judge represents the law, and that practically regards it a crime for a boy to be weak and poor. Much of our common law, it seems to me, is based on might, not right. So he is hurried off to jail at a tender age, and made legally the companion of felons. Now the State has him wholly in her power; by that rough adoption has made him her own child, and sealed the indenture with the jailer's key. His handcuffs are the symbol of his sonship to the State. She shuts him in her college for the little. What does that teach him; science, letters; even morals and religion? Little enough of this, even in Boston, and in most counties of Massachusetts, I think, nothing 
at all, not even a trade which he can practice when his term expires. I have been told a story, and I wish it might be falsely told, of a boy, in this city, of sixteen, sent to the house of correction for five years because he stole a bunch of keys, and coming out of that jail at twenty-one, unable to write, or read, or calculate, and with no trade but that of picking oakum. Yet he had been five years the child of the State, and in that college for the poor! Who would employ such a youth; with such a reputation; with the smell of the jail in his very breath? Not your shrewd men of business, they know the risk; not your respectable men, members of churches and all that; not they! Why, it would hurt a man's reputation for piety to do-goed-in that way. Besides, the risk is great, and it argues a great deal more Christianity than it is popular to have, for a respectable man to employ such a youth. He is forced back into crime again. I say, forced, for honest men will not employ him when the State shoves him out of jail. Soon you will have him in the court again, to be punished more severely. Then he goes to the state prison, and then again, and again, till death mercifully ends his career! 


\section{III}

\section{FREEDOM OR SLAVERY}

\section{By Patrick Henry (I736-i 799)}

[This famous deliberative oration was delivered on March 23, I775, in the Virginia Convention of Delegates. It was a plea for the organization of the Virginia militia. Patrick Henry's complete orations may be found in his Life, Correspondence, and Speeches, edited by William Wirt Henry, New York.

The following is a brief analysis: (I) The illusions of hope. (2) The value of experience. (3) The true meaning of Britain's actions. (4) The means of reconciliation exhausted. (5) An appeal to arms necessary. (6) Objections stated and met. (7) The patriotic decision.]

Mr. President, it is natural to man to indulge in the illusions of hope. We are apt to shut our eyes against a painful truth, and listen to the song of that siren, till she transforms us to beasts. Is this the part of wise men, engaged in a great and arduous struggle for liberty? Are we disposed to be of the number of those who, having eyes, see not, and having ears, hear not, the things which so nearly concern our temporal salvation? For my part, whatever anguish of spirit it may cost, I am willing to know the whole truth; to know the worst, and to provide for it.

I have but one lamp by which my feet are guided; and that is the lamp of experience. I know of no way of judging of the future but by the past. And judging by the past, I wish to know what there has been in the conduct of the British Ministry for the las $\iota$ ten years to justify those hopes with which gentlemen have been 
pleased to solace themselves and the House? Is it that insidious smile with which our petition has been lately received? Trust it not, sir; it will prove a snare to your feet. Suffer not yourselves to be "betrayed with a kiss"! Ask yourselves, how this gracious reception of our petition comports with those warlike preparations which cover our waters and darken our land? Are fleets and armies necessary to a work of love and reconciliation? Have we shown ourselves so unwilling to be reconciled, that force must be called in to win back our love? Let us not deceive ourselves, sir. These are the implements of war and subjugation, the last "arguments" to which kings resort.

I ask gentlemen, sir, what means this martial array, if its purpose be not to force us to submission? Can gentlemen assign any other possible motive for it? Has Great Britain any enemy in this quarter of the world, to call for all this accumulation of navies and armies? No, sir, she has none. They are meant for us; they can be meant for no other. They are sent over to bind and to rivet upon us those chains which the British Ministry have been so long forging. And what have we to oppose to them? Shall we try argument? Sir, we have been trying that for the last ten years. Have we anything new to offer upon the subject? Nothing. We have held the subject up in every light of which it is capable; but it has been all in vain. Shall we resort to entreaty and humble supplication? What terms shall we find which have not been already exhausted? Let us not, I beseech you, sir, deceive ourselves longer. Sir, we have done everything that could 
be done, to avert the storm which is now coming on. We have petitioned, we have remonstrated, we have supplicated, we have prostrated ourselves before the throne, and have implored its interposition to arrest the tyrannical hands of the Ministry and Parliament. Our petitions have been slighted; our remonstrances have produced additional violence and insult; our supplications have been disregarded, and we have been spurned with contempt from the foot of the throne. In vain, after these things, may we indulge in the fond hope of peace and reconciliation. There is no longer any room for hope. If we wish to be free, if we mean to preserve inviolate those inestimable privileges for which we have been so long contending; if we mean not basely to abandon the noble struggle in which we have been so long engaged, and which we have pledged ourselves never to abandon until the glorious object of our contest shall be obtained, we must fight; I repeat it, sir, we must fight! An appeal to arms, and to the God of Hosts, is all that is left us!

They tell us, sir, that we are weak - " unable to cope with so formidable an adversary"! But when shall we be stronger? Will it be the next week, or the next year? Will it be when we are totally disarmed, and when a British guard shall be stationed in every house? Shall we gather strength by irresolution and inaction? Shall we acquire the means of effectual resistance, by lying supinely on our backs, and hugging the delusive phantom of hope, until our enemies have bound us hand and foot? Sir, we are not weak, if we make a proper nuse of those means which the God of Nature hath 
placed in our power. Three millions of people, armed in the holy cause of Liberty, and in such a country as that which we possess, are invincible by any force which our enemy can send against us. Besides, sir, we shall not fight our battles alone. There is a just Power who presides over the destinies of nations, and who will raise up friends to fight our battles for us. The battle, sir, is not to the strong alone; it is to the vigilant, the active, the brave. Besides, sir, we have no election. If we were base enough to desire it, it is now too late to retire from the contest. [There is no retreat, but in submission and slavery. Our chains are forged. Their clanking may be heard on the plains of Boston. The war is inevitable; and let it come! I repeat it, sir, let it come! It is in vain, sir, to extenuate the matter. Gentlemen may cry "Peace, peace!" but there is no peace! The war is actually begun! The next gale that sweeps from the north will bring to our ears the clash of resounding arms! Our brethren are already in the field! Why stand we here idle? What is it that gentlemen wish? What would they have? Is life so dear, or peace so sweet, as to be purchased at the price of chains and slavery? Forbid it, Almighty Powers!I know not what course others may take; but as for me, give me liberty or give me death ! 


\section{IV \\ NAPOLEON TO THE ARMY OF ITALY}

By NAPOleon BoNaparte (1769-1821)

[This demonstrative oration was delivered to the Army of Italy on May 15, 1796, six days after the battle of Lodi. In response, the French beat back the Austrians into Austria, after nearly one year of fierce fighting.

The plan of the address follows:

I. You have done much.

(a) Extent of your achievement.

(b) Its effect upon France.

2. Much still remains to be done.

3. The nature of the fruits of victory.]

Soldiers! You have precipitated yourselves like a torrent from the Apennines. You have overwhelmed or swept before you all that opposed your march. Piedmont, delivered from Austrian oppression, has returned to her natural sentiments of peace and friendship toward France. Milan is yours ; and over all Lombardy floats the flag of the Republic. To your generosity only do the Dukes of Parma and Modena now owe their political existence. The army which proudly threatened you finds no remaining barrier of defense against your courage. The Po, the Ticino, the Adda, could not stop you a single day. Those vaunted ramparts of Italy proved insufficient; you traversed them as rapidly as you did the Apennines. Successes so numerous and brilliant have carried joy to the heart of your country. Your representatives have decreed a festival to be celebrated in all the communes of the Republic, in honor of 
your victories. There will your fathers, mothers, wives, sisters, all who hold you dear, rejoice over your triumphs, and boast that you belong to them.

Yes, soldiers, you have done much; but much still remains for you to do. Shall it be said of us that we knew how to conquer, but not how to profit by victory? Shall posterity reproach us with having found a Capua in Lombardy? Nay, fellow-soldiers! I see you already eager to cry "to arms!" Inaction fatigues you; and days lost to glory are to you days lost to happiness. Let us, then, begone! We have yet many forced marches to make; enemies to vanquish; laurels to gather; and injuries to avenge! Let those who have sharpened the poniards of civil war in France, who have pusillanimously assassinated our Ministers, who have burned our vessels at Toulon, - let them now tremble! The hour of vengeance has knolled!

But let not the people be disquieted. We are the friends of every people; and more especially of the descendants of the Brutuses, the Scipios, and other great men to whom we look as bright exemplars. To reëstablish the Capitol; to place there with honor the statues of the heroes who made it memorable; to rouse the Roman people, unnerved by many centuries of oppression, - such will be some of the fruits of our victories. They will constitute an epoch for posterity. To you, soldiers, will belong the immortal honor of redeeming the fairest portion of Europe. The French people, free and respected by the whole world, shall give to Europe a glorious peace, which shall indemnify it for all the sacrifices which it has borne the last six 
years. Then, by your own firesides you shall repose, and your fellow-citizens, when they point out any one of you, shall say, "He belonged to the army of Italy!"

\section{V \\ DEDICATION OF GETTYSBURG CEMETERY}

By Abraham Lincoln (I809-1865)

[This oration was delivered at the dedication of the National Cemetery at Gettysburg, Pennsylvania, November 19, 1863. It consists of (I) A contrast. (2) What dedication means. (3) A call to patriotic duty.]

Fourscore and seven years ago, our fathers brought forth upon this continent a new nation, conceived in liberty and dedicated to the proposition that all men are created equal. Now we are engaged in a great civil war, testing whether that nation - or any nation so conceived and so dedicated - can long endure.

We are met on a great battlefield of that war. We are met to dedicate a portion of it as the final restingplace of those who have given their lives that that nation might live. It is altogether fitting and proper that we should do this.

But, in a larger sense, we cannot dedicate, we cannot consecrate, we cannot hallow, this ground. The brave men, living and dead, who struggled here, have consecrated it, far above our power to add or to detract. The world will very little note nor long remember what we say here; but it can never forget what they did here.

It is for us, the living, rather, to be dedicated here to the unfinished work they have thus far so nobly carried 
on. It is rather for us to be here dedicated to the great task remaining before us: that from these honored dead we take increased devotion to that cause for which they here gave the last full measure of devotion; that we here highly resolve that these dead shall not have died in vain; that the nation shall, under God, have a new birth of freedom, and that government of the people, by the people, for the people, shall not perish from the earth.

\section{VI \\ A PLEA FOR PATRIOTISM \\ By Benjamin Harrison (I833-I9OI)}

[This extract is from an after-dinner speech given at a banquet in New York City, April 30, 1889. It commemorates the one hundredth anniversary of the inauguration of George Washington as the first President of the United States.

The order of thought is : (I) Congratulations on the observance of the anniversary. (2) Patriotic effect of this observance noted. (3) A plea for a still deeper effect. (4) "Our Country" not a material but a spiritual ideal. (5) A plea for a reconsecration to patriotism.

The address in full will be found in the Nerv York Tribune of May I, 1889.]

I congratulate you to-day, as one of the instructive and interesting features of this occasion, that these great thoroughfares, dedicated to trade, have closed their doors and covered the insignia of commerce with the Stars and Stripes; that your great exchanges have closed, and that into the very heart of Wall Street the flag has been carried. Upon this old historic spot the 
men who give their time and energies to trade have given these days to their country, to the cause of her glory, and to the aspiration for her honor and development.

I have great pleasure in believing that the love of country has been intensified in many hearts here; not only of you who might be called, and some who have been called, to witness your love for the flag in battlefields by sea and land, but in these homes, among these fair women who look down upon us to-night, and in the thoughts of those little children who mingled their piping cries with the hoarser acclaims as we moved along your streets to-day.

I believe that patriotism has been blown into a higher and holier flame in many hearts. These banners with which you have covered your walls, these patriotic inscriptions, must come down, and the ways of commerce and trade be resumed here again.

I will ask you to carry these banners that now hang on the wall into your homes, into the public schools of your city, into all your great institutions where children are gathered, and to drape them there, that the eyes of the young and of the old may look upon that flag as one of the familiar adornments of the American home.

Have we not learned that not stocks nor bonds nor stately houses nor lands nor the products of the mill is our country? It is a spiritual thought that is in our minds. It is the flag and what it stands for. It is its glorious history. It is the fireside and the home. It is the high thoughts that are in the heart, born of the inspiration which comes by the stories of their fathers, 
the martyrs to liberty; it is the graveyards into which our careful country has gathered the unconscious dust of those who have died. Here, in these things, is that thing we love and call our country rather than in anything that can be touched or handled.

To elevate the morals of our people; to hold up the law as that sacred thing, which, like the ark of God of old, cannot be touched by irreverent hands, and frowns upon every attempt to displace its supremacy; to unite our people in all that makes home pure and honorable, as well as to give our energies in the direction of our material advancement, - these services we may render, and out of this great demonstration do we not all feel like reconsecrating ourselves to the love and service of our country?

\section{VII \\ DEFENSE OF ROWAN \\ By John Philpot Curran (1750-1817)}

[The great Irish orator delivered in 1794 the forensic oration from which the following passages are taken. After a masterly plea, he urges the following additional points, as set forth in the excerpta here given :-

The consideration upon which a verdict should be founded is character.

I. Mr. Rowan has a good character.

I. He is known as a public man.

2. He is known as a champion of the helpless.

3. He is known as a charitable man.

II. The inference is, that such a man could not be a lawless person. III. The orator considers the possible verdict.

I. If it be favorable.

2. If it be unfavorable.] 
Gentlemen, if you still have any doubt as to the guilt or innocence of the defendant, give me leave to suggest to you what circumstances you ought to consider, in order to found your verdict. You should consider the character of the person accused; and in this your task is easy. I will venture to say there is not a man in this nation more known than the gentleman who is the subject of this prosecution; not only by the part he has taken in public concerns, and which he has taken in common with many, but still more so by that extraordinary sympathy for human affliction, which, I am sorry to think, he shares with so small a number. There is not a day that you hear the cries of your starving manufacturers in your streets that you do not also see the advocate of their sufferings, - that you do not see his honest and manly figure, with uncovered head, soliciting for their relief, - searching the frozen heart of charity for every string that can be touched by compassion, and urging the force of every argument and every motive, save that which his modesty suppresses, the authority of his own generous example.

Or, if you see him not there, you may trace his steps to the private abodes of disease, and famine, and despair, - the messenger of Heaven, bringing with him food, and medicine, and consolation. Are these the materials of which you suppose anarchy and public rapine to be formed? Is this the man on whom to fasten the abominable charge of goading on a frantic populace to mutiny and bloodshed? Is this the man likely to apostatize from every principle that can bind him to the State, his birth, his property, his education, his character, - 
and to his children? Let me tell you, gentlemen of the jury, if you agree with his prosecutors in thinking that there ought to be a sacrifice of such a man on such an occasion, and upon the credit of such evidence you are to convict him, never did you, never can you, give a sentence, consigning any man to public punishment, with less danger to his person or to his fame; for where, to fling contumely or ingratitude at his head, could the hireling be found, whose private distresses he had not endeavored to alleviate, or whose public condition he had not labored to improve?

I will not relinquish the confidence that this day will be the period to my client's sufferings; and that, however mercilessly he has been hitherto pursued, your verdict will send him home to the arms of his family, and the wishes of his country. But if (which Heaven forbid!) it hath still been unfortunately determined, that, because he has not bent to power and authority,--because he would not bow down before the golden idol, ${ }^{1}$ and worship it, - he is to be bound and cast into the furnace, I do trust in God that there is a redeeming spirit in the Constitution, which will be seen to walk with the sufferer through the flames, and to preserve him unhurt by the conflagration.

${ }^{1}$ The original has the word "calf" in place of "idol." Curran confused Aaron's golden calf (Exodus xxxii.) with Nebuchadnezzar's golden idol, which the three Hebrews refused to worship, and so were thrown into the fiery furnace (Daniel iii.). Had the Irish orator been as faithful a student of the Bible as was Daniel Webster, he would not have fallen into this error. 


\section{VIII \\ THE WAR WITH AMERICA}

\section{By William Pitt, Earl of Chatham (1 708-i778)}

[The elder Pitt's famous deliberative oration was delivered in the House of Lords, November 18, I777. It was on "An Address to the Throne concerning Affairs in America." This was the earl's last speech, for he did not live to see his predictions fulfilled. The outline of the part of the oration here given is simple: (I) Pitt points out the serious crisis. (2) He declares, "You cannot conquer America." (3) He protests against the barbarity of the practice of employing Indians to fight the Americans.]

I cannot, my Lords, I will not, join in congratulation on misfortune and disgrace. I cannot concur in a blind and servile address, which approves and endeavors to sanctify the monstrous measures which have heaped disgrace and misfortune unon us. This, my Lords, is a perilous and tremendous moment! It is not a time for adulation. The smoothness of flattery cannot now avail - cannot save us in this rugged and awful crisis. It is now necessary to instruct the Throne in the language of truth. We must dispel the illusion and the darkness which envelop it, and display, in its full danger and true colors, the ruin that is brought to our doors.

Can the minister of the day now presume to expect a continuance of support in this ruinous infatuation? Can Parliament be so dead to its dignity and its duty as to be thus deluded into the loss of the one and the violation of the other? To give an unlimited credit and support for the steady perseverance in measures not proposed for our parliamentary advice, but dictated and 
forced upon us - in measures, I say, my Lords, which have reduced this late flourishing empire to ruin and contempt! "But yesterday, and England might have stood against the world: now none so poor to do her reverence." The desperate state of our arms abroad is in part known. No man thinks more highly of them than I do. I love and honor the English troops. I know their virtues and their valor. I know they can achieve anything except impossibilities; and I know that the conquest of English America is an impossibility. You cannot, I venture to say it, you cannot conquer America. Your armies in the last war effected everything that could be effected; and what was it? It cost a numerous army, under the command of a most able general, now a noble Lord in this House, ${ }^{1}$ a long and laborious campaign, to expel five thousand Frenchmen from French America. My Lords, you cannot conquer America. What is your present situation there? We do not know the worst; but we know that in three campaigns we have done nothing and suffered much.

You may swell every expense, accumulate every assistance, and extend your traffic to the shambles of every German despot; your attempts will be forever vain and impotent-doubly so, indeed, from this mercenary aid on which you rely; for it irritates, to an incurable resentment, the minds of your adversaries, to over-run them with the mercenary sons of rapine and plunder, devoting them and their possessions to the rapacity of hireling cruelty. If I were an American, as I am an Englishman, while a foreign troop was landed in my

1 Lord Amherst. 
country, I never would lay down my arms-never, never, never!

But, my Lords, who is the man, that, in addition to the disgraces and mischiefs of the war, has dared to authorize and associate to our arms, the tomahawk and scalping-knife of the savage? - to call, into civilized alliance, the wild and inhuman inhabitant of the woods? - to delegate to the merciless Indian the defense of disputed rights, and to wage the horrors of his barbarous war against our brethren? My Lords, these enormities cry aloud for redress and punishment. But, my Lords, this barbarous measure has been defended, not only on the principles of policy and necessity, but also those of morality; " for it is perfectly allowable," says Lord Suffolk, "to use all the means which God and nature have put into our hands." I am astonished, I am shocked, to hear such principles confessed; to hear them avowed in this House, or in this country. My Lords, I did not intend to encroach upon so much of your attention, but I cannot repress my indignation - I feel myself impelled to speak. My Lords, we are called upon, as members of this house, as men, as Christians, to protest against such horrible barbarity! - "That God and nature have put into our hands!" What ideas of God and nature that noble Lord may entertain, I know not; but I know that such detestable principles are equally abhorrent to religion and humanity. What! to attribute the sacred sanction of God and nature to the massacres of the Indian scalping-knife! - to the cannibal savage, torturing, murdering, devouring, drinking the blood of his mangled victims! Such notions shock every precept of morality, 
every feeling of humanity, every sentiment of honor. These abominable principles, and this more abominable avowal of them, demand the most decisive indignation!

\section{IX}

\section{THE NEW AMERICANISM}

\section{By Henry Watterson (1840- )}

[The following after-dinner oration was delivered at the annual meeting of the New England Society, in New York City, December 22, 1894. The New York Tribune of the following day contains the full address. Its outline may be set down as follows: (I) Introductory reference to Henry W. Grady's oration, "The New South." 1 (2) Lincoln the typical American. (3) Appeal to all sections of the country for tolerance.]

Eight years ago to-night, there stood where I am standing now a young Georgian, who, not without reason, recognized the "significance" of his presence here, and, in words whose eloquence I cannot hope to recall, appealed from the New South to New England for a united country.

$\mathrm{He}$ is gone now. But, short as his life was, its heavenborn mission was fulfilled; the dream of his childhood was realized; for he had been appointed by God to carry a message of peace on earth, good will to men, and, this done, he vanished from the sight of mortal eyes, even as the dove from the ark.

Grady told us, and told us truly, of that typical American who, in Dr. Talmage's mind's eye, was coming, but who, in Abraham Lincoln's actuality, had already come. In some recent studies into the career of 
that man, I have encountered many startling confirmations of this judgment; and from that rugged trunk, drawing its sustenance from gnarled roots, interlocked with Cavalier sprays and Puritan branches deep beneath the soil, shall spring, is springing, a shapely tree - symmetric in all its parts - under whose sheltering boughs this nation shall have the new birth of freedom Lincoln promised it, and mankind the refuge which was sought by the forefathers when they fled from oppression. Thank God, the ax, the gibbet, and the stake have had their day. They have gone, let us hope, to keep company with the lost arts. It has been demonstrated that great wrongs may be redressed and great reforms be achieved without the shedding of one drop of human blood; that vengeance does not purify, but brutalizes; and that tolerance, which in private transactions is reckoned a virtue, becomes in public affairs a dogma of the most far-seeing statesmanship.

So I appeal from the men in silken hose who danced to music made by slaves - and called it freedom - from the men in bell-crowned hats, who led Hester Prynne to her shame - and called it religion - to that Americanism which reaches forth its arms to smite wrong with reason and truth, secure in the power of both. I appeal from the patriarchs of New England to the poets of New England; from Endicott to Lowell; from Winthrop to Longfellow; from Norton to Holmes; and I appeal in the name and by the rights of that common citizenship - of that common origin - back of both the Puritan and the Cavalier - to which all of us owe our being. Let the dead past, çonsecrated by the blood of 
its martyrs, not by its savage hatreds - darkened alike by kingcraft and priestcraft - let the dead past bury its dead. Let the present and the future ring with the song of the singers. Blessed be the lessons they teach, the laws they make. Blessed be the eye to see, the light to reveal. Blessed be Tolerance, sitting ever on the right hand of God to guide the way with loving word, as blessed be all that brings us nearer the goal of true religion, true Republicanism, and true patriotism, distrust of watchwords and labels, shams and heroes, belief in our country and ourselves. It was not Cotton Mather, but John Greenleaf Whittier, who cried :-

"Dear God and Father of us all, Forgive our faith in cruel lies, Forgive the blindness that denies.

"Cast down our idols - overturn Our bloody altars - make us see Thyself in Thy humanity!"

\section{$\mathrm{X}$}

THE GUILLOTINE

By Victor Hugo (I802-1885)

[This passionate fragment of forensic eloquence was spoken in defense of the orator's son, under circumstances set forth in the oration itself.

(I) The orator "denounces" himself and defends his son. (2) He then attacks the law. (3) Next, he narrates the circumstances which led up to his son's protest. (4) Finally, he presents the protest in its true light, and submits the case to the jury.]

Gentlemen of the Jury, if there is a culprit here, it is not my son, - it is I-I, who for these twenty-five 
years have opposed capital punishment, - have contended for the inviolability of human life, - have committed this crime for which my son is now arraigned. Here-I-denounce myself,-Mr. Advocate General! I have committed it under all aggravated circumstances; deliberately, repeatedly, tenaciously. Yes, this old and absurd lex talionis - this law of blood for blood - I have combated all my life all my life, Gentlemen of the fury! And, while I have breath, II will continue to combat it, by all my efforts as a writer, by all my words and all my votes as a legislator! I declare it before the crucifix; before that Victim of the penalty of death, who sees and hears us; before that gibbet, to which, two thousand years ago, for the eternat instruction of the generations; the human law nailed the Divine!

In all that my son has written on the subject of capital punishment and for writing and publishing which he is now on trial, - in all that he has written, he has merely proclaimed the sentiments with which, from his infancy, I have inspired him. Gentlemen Jurors, the right to criticise a law, and to eritieise-it severely - especially a penal law - is placed beside the duty of amelioration, like the torch beside the work under the artisan's hand. The right of the journalist is as sacred, as necessary, as imprescriptible, as the right of the legislator.

What are the circumstances? A man, a convict, a sentenced wretch, is dragged, on a certain morning, to one of our public squares. There he finds the scaffold! $\mathrm{He}$ shudders, he struggies, he refuses to die. $\mathrm{He}$ is young yet - only twenty-nine. Ah! I know what you 
will say, - "He is a murderer!" But hear me. Two officers seize him. His hands, his feet, are tied. $\mathrm{He}$ throws off the two officers. A frightful struggle ensues. His feet, bound as they are, become entangled in the ladder. He uses the scaffold against the scaffold! The stuggle is prolonged. Horror seizes on the crowd. The officers, - sweat and shame on their brows, - pale, panting, terrified, despairing, cesparing with I know not what horrible despair, - shrinking under that public reprobation which ought to have visited the penalty, and spared the-passive-instrument, the executioner; - the officers strive savagely. The victim clings to the scaffold, and shrieks for pardon. His clothes are torn, his shoulders bloody, - still he resists. At length, after three quarters of an hour of this monstrous effort, of this spectacle without a name, of this agony, -agony for-all, be-it understoed, - agony for the assembled spectators as well as for the condemned man, - after this age of anguish, Gentlemen of the Jury, they take back the poor wretch to his prison.

The People breathe again. The People, naturally merciful, hope that the man will be spared. But no, the guillotine, though vanquished, remains standing. There it frowns all day, in the midst of a sickened population. And at night, the officers, reënforced, drag forth the wretch again, so bound that he is but an inert weight, - they drag him forth, haggard, bloody, weeping, pleading, howling for life, - calling upon God, calling upon his father and mother, - for like a very child had this man become in the prospect of death, - they drag him forth to execution. He is hoisted on the scaffold, 
and his head falls! - And then through everenseience runs a shudder. Never had legal murder appeared with an aspect so indecent, so abominable. All feel jointly implicated in the deed. It is at this-yery moment that from a young man's breast escapes a cry, wrung from his very heart, - a cry of pity and of anguish, - a cry of horror, - a cry of humanity. And this cry you would punish! And in the face of the appalling facts which I have narrated, you would say to the guillotine, "Thou art right!" and to Pity, saintly Pity, "Thou art wrong!" Gentlemen of the Jury, it cannot be! Gentlemen, I have finished.

\section{$\mathrm{XI}$}

\section{ADDRESS TO THE AMERICAN TROOPS}

By George WAshington (I732-I799)

[This demonstrative address was spoken to the patriot soldiery just before the battle of Long Island, August 27, 1776. It consists of three thought-divisions: (I) Washington presents the alternatives. (2) He urges the motives for heroic resistance. (3) Final appeal and directions.

Washington's complete writings have been published under the editorship of W. C. Ford, New York, I 888.]

The time is now near at hand which must probably determine whether Americans are to be freemen or slaves; whether they are to have any property they can call their own; whether their houses and farms are to be pillaged and destroyed, and themselves consigned to a state of wretchedness from which no human efforts will deliver them. The fate of unborn millions will now depend, under God, on the courage and/conduct of this 
army. Our cruel and unrelenting enemy leaves us only the choice of a brave resistance, or the most abject submission. We have, therefore, to resolve to conquer or to die. "Our own, our country's honor, calls upon us for a vigorous and manly exertion; and if we now shamefully fail, we shall become infamous to the whole world. Let us, then, rely on the goodness of our cause, and the aid of the Supreme Being, in whose hands victory is, to animate and encourage us to great and noble actions. The eyes of all our countrymen are now upon us: and we shall have their blessings and praises, if happily we are the instruments of saving them from the tyranny meditated against them. Let us, therefore, animate and encourage each other, and show the whole world that a freeman contending for liberty on his own ground is superior to any slavish mercenary on earth.

Liberty, property, life, and honor, are all at stake. Upon your courage and conduct rest the hopes of our bleeding and insulted country. Our wives, children, and parents expect safety from us only; and they have every reason to believe that Heaven will crown with success so just a cause. The enemy will endeavor to intimidate by show and appearance; but remember they have been repulsed on various occasions by a few brave Americans. Their cause is bad - their men are conscious of it; and, if opposed with firmness and coolness on their first onset, with our advantage of works, and knowledge of the ground, the victory is most assuredly ours. Every good soldier will be silent and attentive, wait for orders, and reserve his fire until he is sure of doing execution. 


\section{XII}

\section{ROBESPIERRE'S LAST SPEECH}

By Maximilian Marie Isidore de Robespierre (I758-1794)

[Before his execution on the guillotine, Robespierre addressed the populace of Paris. His words consist of: (I) A defence against the charge that he was a tyrant. (2) An explanation of his true motives. (3) A declaration that he is superior to mere personal considerations. (4) An appeal to history. (5) An appeal to France.]

The enemies of the Republic call me tyrant! Were I such they would grovel at my feet. I should gorge them with gold, I should grant them immunity for their crimes, and they would be grateful. Were I such, the kings we have vanquished, far from denouncing Robespierre, would lend me their guilty support; there would be a covenant between them and me. Tyranny must have tools. But the enemies of tyranny, - whither does their path tend? To the tomb, and to immortality! What tyrant is my protector? To what faction do I belong? Yourselves! What faction, since the beginning of the Revolution, has crushed and annihilated so many detected traitors? You, the people, - our principles, are that faction - a faction to which I am devoted, and against which all the scoundrelism of the day is banded!

The confirmation of the Republic has been my object; and I know that the Republic can be established only on the eternal basis of morality. Against me, and against those who hold kindred principles, the league is formed. My life? Oh! my life I abandon without a 
regret! I have seen the past; and I foresee the future. What friend of this country would wish to survive the moment when he could no longer serve it, - when he could no longer defend innocence against oppression? Wherefore should I continue in an order of things, where intrigue eternally triumphs over truth; where justice is mocked; where passions the most abject, or fears the most absurd, over-ride the sacred interests of humanity? In witnessing the multitude of vices which the torrent of the Revolution has rolled in turbid communion with its civic virtues, I confess that I have sometimes feared that I should be sullied, in the eyes of posterity, by the impure neighborhood of unprincipled men, who had thrust themselves into association with the sincere friends of humanity; and I rejoice that these conspirators against my country have now, by their reckless rage, traced deep the line of demarcation between themselves and all true men.

Question history, and learn how all the defenders of liberty, in all times, have been overwhelmed by calumny. But their traducers died also. The good and the bad disappear alike from the earth; but in very different conditions. O Frenchmen! O my countrymen! Let not your enemies, with their desolating doctrines, degrade your souls, and enervate your virtues! No, Chaumette, no! Death is not "an eternal sleep"! Citizens! efface from the tomb that motto, graven by sacrilegious hands, which spreads over all nature a funereal crape, takes from oppressed innocence its support, and affronts the beneficent dispensation of death! Inscribe rather thereon these words: "Death is the commencement of 
immortality!" I leave to the oppressors of the People a terrible testament, which I proclaim with the independence befitting one whose career is so nearly ended; it is the awful truth, _ " Thou shalt die!"

\section{XIII}

\section{THE GLORIES OF THE DAWN}

\section{By Edward EveretT (1794-1865)}

[The following descriptive passage is from an oration delivered in Albany, New York, August 28, 1856.]

Much as we are indebted to our observatories for elevating our conceptions of the heavenly bodies, they present even to the unaided sight scenes of glory which words are too feeble to describe. I had occasion, a few weeks since, to take the early train from Providence to Boston; and for this purpose rose at two o'clock in the morning. Everything around was wrapped in darkness and hushed in silence, broken only by what seemed at that hour the unearthly clank and rush of the train. It was a mild, serene, midsummer's night - the sky was without a cloud - the winds were whist. The moon, then in the last quarter, had just risen, and the stars shone with a special lustre but little affected by her presence. Jupiter, two hours high, was the herald of the day; the Pleiades, just above the horizon, shed their sweet influence in the east; Lyra sparkled near the zenith; Andromeda veiled her newly discovered glories from the naked eye in the south; the steady pointers far beneath the pole looked meekly up from the depth of the north to their sovereign. 
Such was the glorious spectacle as I entered the train. As we proceeded, the timid approach of twilight became more perceptible; the intense blue of the sky began to soften; the smaller stars, like little children, went first to rest; the sister beams of the Pleiades soon melted together; but the bright constellations of the west and north remained unchanged. Steadily the wondrous transfiguration went on. Hands of angels hidden from mortal eyes shifted the scenery of the heavens; the glories of night dissolved into the glories of the dawn. The blue sky now turned more softly gray; the great watch-stars shut up their holy eyes; the east began to kindle. Faint streaks of purple soon blushed along the sky; the whole celestial concave was filled with the inflowing tides of the morning light, which came pouring down from above in one great ocean of radiance; till at length, as we reached the Blue Hills, a flash of purple fire blazed out from above the horizon, and turned the dewy tear-drops of flower and leaf into rubies and diamonds. In a few seconds the everlasting gates of the morning were thrown wide open, and the lord of day, arrayed in glories too severe for the gaze of man, began his state.

\section{XIV}

\section{EULOGY OF LINCOLN}

By John Philip Newman (1826- )

Human glory is often fickle as the winds, and transient as a summer day; but Abraham Lincoln's place in history is assured. All the symbols of this world's 
admiration are his. He is embalmed in song, recorded in history, eulogized in panegyric, cast in bronze, sculp. tured in marble, painted on canvas, enshrined in the hearts of his countrymen, and lives in the memories of mankind. Some men are brilliant in their times, but their words and deeds are of little worth to history; but his mission was as large as his country, vast as humanity, enduring as time. No greater thought can ever enter the human mind than obedience to law and freedom for all. Some men are not honored by their contemporaries, and die neglected. Here is one more honored than any other man while living, more revered when dying, and destined to be loved to the last syllable of recorded time. He has this threefold greatness - great in life, great in death, great in the history of the world. Lincoln will grow upon the attention and affections of posterity, because he saved the life of the greatest nation, whose ever widening influence is to bless humanity. Measured by this standard, Lincoln shall live in history from age to age.

Great men appear in groups, and in groups they disappear from the vision of the world; but we do not love or hate men in groups. We speak of Gutenberg and his coadjutors, of Washington and his generals, of Lincoln and his cabinet; but when the day of judgment comes, we crown the inventor of printing, we place the laurel on the brow of the father of his country, and the chaplet of renown upon the head of the savior of the republic.

Some men are great from the littleness of their surroundings; but he only is great who is great amid 
greatness. Lincoln had great associates - Seward, the sagacious diplomatist; Chase, the eminent financier; Stanton, the incomparable Secretary of War, - with illustrious senators and soldiers. Neither could take his part nor fill his position. And the same law of the coming and going of great men is true of our own day. In piping times of peace genius is not aflame, and true greatness is not apparent; but when the crisis comes, then God lifts the curtain from obscurity and reveals the man for the hour.

Lincoln stands forth on the page of history, unique in his character, and magnetic in his individuality. Like Milton's angel, he was an original conception. He was raised up for his times. He was a leader of leaders. By instinct the common heart trusted him. He was of the people and for the people. He had been poor and laborious; but greatness did not change the tone of his spirit or lessen the sympathies of his nature. His character was strangely symmetrical. He was temperate, without austerity; brave, without rashness; constant, without obstinacy. He put caution against hope, that it might not be premature; and hope against caution, that it might not yield to dread or danger. His marvelous hopefulness never betrayed him into impracticable measures. His love of justice was only equaled by his delight in compassion. His regard for personal honor was only excelled by love of country. His self-abnegation found its highest expression in the public good. His integrity was never questioned. His honesty was above suspicion. He was more solid than brilliant; his judgment dominated his imagination; his ambition was 
subject to his modesty; and his love of justice held the mastery over all personal considerations. Not excepting Washington, who inherited wealth and high social position, Lincoln is the fullest representative American in our national annals. He had touched every round in the human ladder. He illustrated the possibilities of our citizenship. We are not ashamed of his humble origin. We are proud of his greatness.

We are to judge men by their surroundings and measure their greatness by the difficulties which they surmounted. Every age has its heroes, every crisis its master. Lincoln came into power in the largest and most violent political convulsion known to history. In nothing is the sagacity and might of Lincoln's statesmanship more apparent than in his determination to save the Union of these States. This was the objective point of his administration. He denied state sovereignty as paramount to national sovereignty. States have their rights and their obligations; and their chief obligation is to remain in the Union. Some political philanthropists clamored for the overthrow of slavery, and advocated the dissolution of the Union rather than live in a country under whose government slavery was tolerated. But Lincoln was a wiser and a better philanthropist than they. He would have the Union, with or without slavery. He preferred it without, and his preference prevailed. How incomparably worse would have been the condition of the slave in a Confederacy with a living slave for its corner-stone than in the Union of the States! Time has vindicated the character of his statesmanship, that to preserve the Union was to save this 
great nation for human liberty, and thereby advance the emancipated slave to education, thrift, and political equality.

\section{XV}

A PLEA FOR CUBA

By John Mellen Thurston (1847- )

[This deliberative oration was delivered in the United States Senate on March 24, I898. It is recorded in full in the Congressional Record of that date. Mrs. Thurston died in Cuba. As a dying request she urged her husband, who was investigating affairs in the island, to do his utmost to induce the United States to intervene-hence this oration.]

Mr. President, I am here by command of silent lips to speak once and for all upon the Cuban situation. I shall endeavor to be honest, conservative, and just. I have no purpose to stir the public passion to any action not necessary and imperative to meet the duties and necessities of American responsibility, Christian humanity, and national honor. I would shirk this task if I could, but I dare not. I cannot satisfy my conscience except by speaking, and speaking now.

I went to Cuba firmly believing that the condition of affairs there had been greatly exaggerated by the press, and my own efforts were directed in the first instance to the attempted exposure of these supposed exaggerations. There has undoubtedly been much sensationalism in the journalism of the time, but as to the condition of affairs in Cuba, there has been no exaggeration, because exaggeration has been impossible. 
Under the inhuman policy of Weyler not less than four hundred thousand self-supporting, simple, peaceable, defenseless country people were driven from their homes in the agricultural portions of the Spanish provinces to the cities, and imprisoned upon the barren waste outside the residence portions of these cities and within the lines of intrenchment established a little way beyond. Their humble homes were burned, their fields laid waste, their implements of husbandry destroyed, their live stock and food supplies for the most part confiscated. / Most of the people were old men, women, and children. They were thus placed in hopeless imprisonment, without shelter or food. There was no work for them in the cities to which they were driven. They were left with nothing to depend upon except the scanty charity of the inhabitants of the cities and with slow starvation their inevitable fate. . . .

The pictures in the American newspapers of the starving reconcentrados are true. They can all be duplicated by the thousands. I never before saw, and please God I may never again see, so deplorable a sight as the reconcentrados in the suburbs of Matanzas. I can never forget to my dying day the hopeless anguish in their despairing eyes. Huddled about their little bark huts, they raised no voice of appeal to us for alms as we went among them. . . .

Men, women, and children stand silent, famishing with hunger. Their only appeal comes from their sad eyes, through which one looks as through an open window into their agonizing souls.

The government of Spain has not appropriated and 
will not appropriate one dollar to save these people. They are now being attended and nursed and administered to by the charity of the United States. Think of the spectacle! We are feeding these citizens of Spain; we are nursing their sick; we are saving such as can be saved, and yet there are those who still say it is right for us to send food, but we must keep hands off. I say that the time has come when muskets ought to go with the food.

We asked the governor if he knew of any relief for these people except through the charity of the United States. He did not. We asked hirn, "When do you think the time will come that these people can be placed in a position of self-support?" He replied to us, with deep feeling, "Only the good God or the great government of the United States will answer that question." I hope and believe that the good God by the great government of the United States will-answer that question.

I shall refer to these horrible things no further. They are there. God pity me, I have seen them; they will remain in my mind forever - and this is almost the twentieth century. Christ died nineteen hundred years ago, and Spain is a Christian nation. She has set up more crosses in more lands, beneath more skies, and under them has butchered more people than all the other nations of the earth combined. Europe may tolerate her existence as long as the people of the Old World wish. God grant that before another Christmas morning the last vestige of Spanish tyranny and oppression will have vanished from the Western Hemisphere !... 
The time for action has come. No greater reason for it can exist to-morrow than exists to-day, Every hour's delay only adds another chapter to the awful story of misery and death. Only one power can intervenethe United States of America. Ours is the one great nation in the world, the mother of American republics. She holds a position of trust and responsibility toward the peoples and affairs of the whole Western Hemisphere. It was her glorious example which inspired the patriots of Cuba to raise the flag of liberty in her eternal hills. We cannot refuse to accept this responsibility which the God of the universe has placed upon us as the one great power in the New World. We must act! What shall our action be?

Against the intervention of the United States in this holy cause there is but one voice of dissent; that voice is the voice of the money-changers. They fear war! Not because of any Christian or ennobling sentiment against war and in favor of peace, but because they fear that a declaration of war, or the intervention which might result in war, would have a depressing effect upon the stock market. Let them go. They do not represent American sentiment; they do not represent American patriotism. Let them take their chances as they can. Their weal or woe is of but little importance to the liberty-loving people of the United States. They will not do the fighting; their blood will not flow ; they will keep on dealing in options on human life. Let the men whose loyalty is to the dollar stand aside while the men whose loyalty is to the flag come to the front.

Mr. President, there is only one action possible, if 
any is taken; that is, intervention for the independence of the island. But we cannot intervene and save Cuba without the exercise of force, and force means war; war means blood. The lowly Nazarene on the shores of Galilee preached the divine doctrine of love, "Peace on earth, good will toward men." Not peace on earth at the expense of liberty and humanity. Not good will toward men who despoil, enslave, degrade, and starve to death their fellow-men. I believe in the doctrine of Christ. I believe in the doctrine of peace; but, $\mathrm{Mr}$. President, men must have liberty before there can come abiding peace.

Intervention means force. Force means war. War means blood. But it will be God's force. When has a battle for humanity and liberty ever been won except by force? What barricade of wrong, injustice, and oppression has ever been carried except by force?

Force compelled the signature of unwilling royalty to the great Magna Charta; force put life into the Declaration of Independence and made effective the Emancipation Proclamation; force beat with naked hands upon the iron gateway of the Bastile and made reprisal in one awful hour for centuries of kingly crime; force waved the flag of revolution over Bunker Hill and marked the snows of Valley Forge with blood-stained feet; force held the broken line of Shiloh, climbed the flame-swept hill at Chattanooga, and stormed the clouds on Lookout Heights ; force marched with Sherman to the sea, rode with Sheridan in the valley of the Shenandoah, and gave Grant victory at Appomattox; force saved the Union, kept the stars in the flag, made "niggers" men. 
The time for God's force has come again. Eet the impassioned lips of American patriots once more take up the song:-

"In the beauty of the lilies, Christ was born across the sea, With a glory in His bosom that transfigures you and me; As He died to make men holy, let us die to make men free, While God is marching on."

Others may hesitate, others may procrastinate, others may plead for further diplomatic negotiation, which means delay; but for me, I am ready to act now, and for my action $I$ am ready to answer to my conscience, my country, and my God.

\section{XVI}

\section{THE NEW SOUTH}

\section{By Henry Woodfin Grady (1850-1889)}

[Mr. Grady's now famous after-dinner oration was delivered before the New England Society of New York City, on the occasion of their eighty-first annual banquet, December 22, I886. It was as nearly an impromptu effort as any great speech can be.]

"There was a South of slavery and secession - that South is dead. There is a South of union and freedom — that South, thank God, is living, breathing, growing every hour." These words, delivered from the immortal lips of Benjamin H. Hill, at Tammany Hall, in I866, true then, and truer now, I shall make my text to-night.

Mr. President and Gentlemen: Let me express to you my appreciation of the kindness by which I am permitted to address you. I make this abrupt acknowledg.. 
ment advisedly, for I feel that if, when I raised my provincial voice in this ancient and august presence, I could find courage for no more than the opening sentence, it would be well if, in that sentence, I had met in a rough sense my obligation as a guest, and had perished, so to speak, with courtesy on my lips and grace in my heart.

Permitted, through your kindness, to catch my second wind, let me say that I appreciate the significance of being the first Southerner to speak at this board, which bears the substance, if it surpasses the semblance of original New England hospitality, and honors a sentiment that in turn honors you, but in which my personality is lost and the compliment to my people made plain.

I bespeak the utmost stretch of your courtesy tonight. I am not troubled about those from whom I come. You remember the man whose wife sent him to a neighbor with a pitcher of milk, and who, tripping on the top step, fell, with such casual interruptions as the landings afforded, into the basement, and, while picking himself up, had the pleasure of hearing his wife call out : "John, did you break the pitcher?"

"No, I didn't," said John, "but I be dinged if I don't."

So, while those who call to me from behind may inspire me with energy, if not with courage, I ask an indulgent hearing from you. I beg that you will bring your full faith in American fairness and frankness to judgment upon what I shall say. There was an old preacher once who told some boys of the Bible lesson he was going to read in the morning. The boys, find- 
ing the place, glued together the connecting pages. The next morning he read on the bottom of one page: "When Noah was one hundred and twenty years old he took unto himself a wife, who was" - then turning the page - " one hundred and forty cubits long, forty cubits wide, built of gopher wood, and covered with pitch inside and out." He was naturally puzzled at this. $\mathrm{He}$ read it again, verified it, and then said, "My friends, this is the first time I ever met this in the Bible, but I accept it as an evidence of the assertion that we are fearfully and wonderfully made." If I could get you to hold such faith to-night, I could proceed cheerfully to the task I otherwise approach with a sense of consecration.

Pardon me one word, Mr. President, spoken for the sole purpose of getting into the volumes that go out annually freighted with the rich eloquence of your speakers - the fact that the Cavalier, as well as the Puritan, was on the continent in its early days, and that he was "up and able to be about." I have read your books carefully and I find no mention of that fact, which seems to me an important one for preserving a sort of historical equilibrium, if for nothing else.

Let me remind you that the Virginia Cavalier first challenged France on this continent; that Cavalier John Smith gave New England its very name, and was so pleased with the job that he has been handing his own name around ever since; and that while Miles Standish was cutting off men's ears for courting a girl without her parents' consent, and forbade men to kiss their wives on Sunday, the Cavalier was courting everything in sight; and that the Almighty had vouchsafed great 
increase to the Cavalier colonies, the huts in the wilder. ness being as full as the nests in the woods.

But having incorporated the Cavalier as a fact in your charming little book, I shall let him work out his own salvation, as he has always done with engaging gallantry, and we will hold no controversy as to his merits. Why should we? Neither Puritan nor Cavalier long survived as such. The virtues and traditions of both happily still live for the inspiration of their sons and the saving of the old fashion. Both Puritan and Cavalier were lost in the storm of the first Revolution, and the American citizen, supplanting both, and stronger than either, took possession of the republic bought by their common blood and fashioned to wisdom, and charged himself with teaching men government and establishing the voice of the people as the voice of God.

My friend, Dr. Talmage, has told you that the typical American has yet to come. Let me tell you that he has already come. Great types, like valuable plants, are slow to flower and fruit. But from the union of these colonist Puritans and Cavaliers, from the straightening of their purposes and the crossing of their blood, slow perfecting through a century, came he who stands as the first typical American, the first who comprehended within himself all the strength and gentleness, all the majesty and grace of this republic, Abraham Lincoln. He was the sum of Puritan and Cavalier; for in his ardent nature were fused the virtues of both, and in the depths of his great soul the faults of both were lost. $\mathrm{He}$ was greater than Puritan, greater than Cavalier, in that he was American, and that in his 
homely form were first gathered the vast and thrilling forces of his ideal government charging it with such tremendous meaning, and so elevating it above human suffering, that martyrdom, though infamously aimed, came as a fitting crown to a life consecrated, from the cradle, to human liberty. Let us, each cherishing the traditions and honoring his fathers, build with reverent hands to the type of his simple but sublime life, in which all types are honored; and in our common glory as Americans there will be plenty and some to spare for your forefathers and for mine.

In speaking to the toast with which you have honored me, I accept the term, "The New South," as in no sense disparaging to the old. Dear to me, sir, is the home of my childhood and the traditions of my people. I would not, if I could, dim the glory they won in peace and war, or by word or deed take aught from the splendor and grace of their civilization, never equaled, and perhaps never to be equaled in its chivalric strength and grace. There is a New South, not through protest against the old, but because of new conditions, new adjustments, and, if you please, new ideas and aspirations. It is to this that I address myself, and to the consideration of which I hasten, lest it become the Old South before I get to it. Age does not endow all things with strength and virtue, nor are all new things to be despised. The shoemaker who put over his door, "John Smith's shop, founded I760," was more than matched by his young rival across the street who hung out this sign: "Bill Jones. Established I886. No old stock kept in this shop." 
Dr. Talmage has drawn for you, with a master hand, the picture of your returning armies. He has told you how, in the pomp and circumstance of war, they came back to you, marching with proud and victorious tread, reading their glory in a nation's eyes! Will you bear with me while I tell you of another army that sought its home at the close of the late war? An army that marched home in defeat and not in victory - in pathos and not in splendor, but in. glory that equaled yours, and to hearts as loving as ever welcomed heroes home. Let me picture to you the footsore Confederate soldier, as, buttoning up in his faded gray jacket the parole which was to bear testimony to his children of his fidelity and faith, he turned his face southward from Appomattox in April, I865. Think of him as ragged, halfstarved, heavy-hearted, enfeebled by want and wounds; having fought to exhaustion, he surrenders his gun, wrings the hands of his comrades in silence, and, lifting his tear-stained and pallid face for the last time to the graves that dot the old Virginia hills, pulls his gray cap over his brow and begins the slow and painful journey. What does he find? - let me ask you who went to your homes eager to find, in the welcome you had justly earned, full payment for four years' sacrifice - what does he find when, having followed the battle-stained cross against overwhelming odds, dreading death not half so much as surrender, he reaches the home he left so prosperous and beautiful? He finds his house in ruins, his farm devastated, his slaves free, his stock killed, his barn empty, his trade destroyed, his money worthless; his social system, feudal in its magnificence, 
swept away; his feople without law or legal status; his comrades slain, ind the burdens of others heavy on his shoulders. Crushed by defeat, his very traditions gone; without money, credit, employment, material training; and besides all this, confronted with the gravest problem that ever met human intelligence - the establishment of a status for the vast body of his liberated slaves.

What does he do - this hero in gray, with a heart of gold? Does he sit down in sullenness and despair? Not for a day. Surely God, who had stripped him of his prosperity, inspired him in his adversity. As ruin was never before so overwhelming, never was restoration swifter. The soldier stepped from the trenches into the furrow; horses that had charged Federal guns marched before the plow; and the fields that ran red with human blood in April were green with the harvest in June; women reared in luxury cut up their dresses and made breeches for their husbands, and, with a patience and heroism that fit women always as a garment, gave their hands to work. There was little bitterness in all this. Cheerfulness and frankness prevailed. "Bill Arp" struck the keynote when he said, "Well, I killed as many of them as they did of me, and now I am going to work." Or the soldier, returning home after defeat and roasting some corn on the roadside, who made the remark to his comrade, "You may leave the South if you want to; but I am going to Sandersville, kiss my wife, and raise a crop, and if the Yankees fool with me any more I will whip 'em again." I want to say to General Sherman - who is considered an able man in our 
parts, though some people think he is kind of careless about fire - that from the ashes he left us in I 864 we have raised a brave and beautiful city; that somehow or other we have caught the sunshine in the bricks and mortar of our homes, and have builded therein not one ignoble prejudice or memory.

But in all this what have we accomplished? What is the sum of our work? We have found out that in the general summary the free negro counts more than he did as a slave. We have planted the schoolhouse on the hilltop and made it free to white and black. We have sowed towns and cities in the place of theories, and put business above politics. We have learned that the $\$ 400,000,000$ annually received from our cotton crop will make us rich, when the supplies that make it are home-raised. We have reduced the commercial rate of interest from twenty-four to four per cent, and are floating four per cent bonds. We have learned that one Northern immigrant is worth fifty foreigners, and have smoothed the path to the southward, wiped out the place where Mason and Dixon's line used to be, and hung out our latchstring to you and yours.

We have reached the point that marks perfect harmony in every household, when the husband confesses that the pies which his wife cooks are as good as those his mother used to bake; and we admit that the sun shines as brightly and the moon as softly as it did "before the war." We have established thrift in the city and country. We have fallen in love with work. We have restored comforts to homes from which culture and elegance never departed. We have let economy take 
root and spread among us as rank as the crab-grass which sprung from Sherman's cavalry camps, until we are ready to lay odds on the Georgia Yankee, as he manufactures relics of the battlefield in a one-story shanty, and squeezes pure olive oil out of his cotton seed, against any down-easter that ever swapped wooden nutmegs for flannel sausages in the valley of Vermont.

Above all, we know that we have achieved in these "piping times of peace" a fuller independence for the South than that which our fathers sought to win in the forum by their eloquence, or compel on the field by their swords.

It is a rare privilege, sir, to have had a part, however humble, in this work. Never was nobler duty confided to human hands than the uplifting and upbuilding of the prostrate and bleeding South, misguided, perhaps, but beautiful in her suffering, and honest, brave, and generous always. In the record of her social, industrial, and political restoration we await with confidence the verdict of the world.

But what of the negro? Have we solved the problem he presents, or progressed in honor and equity toward the solution? Let the record speak to the point. No section shows a more prosperous laboring population than the negroes of the South; none in fuller sympathy with the employing and land-owning class. He shares our school fund, has the fullest protection of our laws, and the friendship of our people. Self-interest, as well as honor, demands that they should have this. Our future, our very existence, depends upon our working out this problem in full and exact justice. We understand 
that when Lincoln signed the Emancipation Proclamation, your victory was assured; for he then committed you to the cause of human liberty, against which the arms of man cannot prevail; while those of our statesmen who trusted to make slavery the cornerstone of the Confederacy doomed us to defeat as far as they could, committing us to a cause that reason could not defend or the sword maintain in the sight of advancing civilization. Had Mr. Toombs said, which he did not say, that he would call the roll of his slaves at the foot of Bunker Hill, he would have been foolish, for he might have known that whenever slavery became entangled in war it must perish, and that the chattel in human flesh ended forever in New England when your fathers - not to be blamed for parting with what did not pay - sold their slaves to our fathers - not to be praised for knowing a paying thing when they saw it.

The relations of the Southern people with the negro are close and cordial. We remember with what fidelity for four years he guarded our defenseless women and children, whose husbands and fathers were fighting against his freedom. To his credit be it said that whenever he struck a blow for his own liberty he fought in open battle, and when at last he raised his black and humble hands that the shackles might be struck off, those hands were innocent of wrong against his help? ess charges, and worthy to be taken in loving grasp by every man who honors loyalty and devotion.

Ruffians have maltreated him, rascals have misled him, philanthropists established a bank for him; but the South with the North protest against injustice to this 
simple and sincere people. To liberty and enfranchisement is as far as the law can carry the negro. The rest must be left to conscience and common sense. It should be left to those among whom his lot is cast, with whom he is indissolubly connected, and whose prosperity depends upon their possessing his intelligent sympathy and confidence. Faith has been kept with him in spite of calumnious assertions to the contrary by those who assume to speak for us, or by frank opponents. Faith will be kept with him in the future, if the South holds her reason and integrity.

But have we kept faith with you? In the fullest sense, yes. When Lee surrendered - I don't say when Johnston surrendered, because I understand he still alludes to the time when he met General Sherman last as the time when he "determined to abandon any further prosecution of the struggle" - when Lee surrendered, I say, and Johnston quit, the South became, and has been, loyal to the Union. We fought hard enough to know that we were whipped, and in perfect frankness accepted as final the arbitrament of the sword to which we had appealed. The South found her jewel in the toad's head of defeat. The shackles that had held her in narrow limitations fell forever when the shackles of the negro slave were broken.

Under the old régime the negroes were slaves to the South, the South was a slave to the system. The old plantation, with its simple police regulations and its feudal habit, was the only type possible under slavery. Thus was gathered in the hands of a splendid and chivalric oligarchy the substance that should have been diffused 
among the people, as the rich blood, under certain artificial conditions, is gathered at the heart, filling that to affluent rupture, but leaving the body chill and colorless.

The old South rested everything on slavery and agriculture, unconscious that these could neither give nor maintain healthy growth. The new South presents a perfect democracy, the oligarchs leading in the popular movement - a social system compact and closely knitted, less splendid on the surface but stronger at the core; a hundred farms for every plantation, fifty homes for every palace, and a diversified industry that meets the complex needs of this complex age.

The new South is enamored of her new work. Her soul is stirred with the breath of a new life. The light of a grander day is falling fair on her face. She is thrilling with the consciousness of a growing power and prosperity. As she stands upright, full-statured and equal among the people of the earth, breathing the keen air and looking out upon the expanding horizon, she understands that her emancipation came because in the inscrutable wisdom of God her honest purpose was crossed and her brave armies were beaten.

This is said in no spirit of time-serving or apology. The South has nothing for which to apologize. She believes that the late struggle between the States was war and not rebellion, revolution and not conspiracy, and that her convictions were as honest as yours. I should be unjust to the dauntless spirit of the South and to my own convictions if I did not make this plain in this presence. The South has nothing to take back. In my native town of Athens is a monument that crowns 
its central hills - a plain, white shaft. Deep cut into its shining side is a name dear to me above the names of men, that of a brave and simple man who died in a brave and simple faith. Not for all the glories of New England - from Plymouth Rock all the way-would I exchange the heritage he left me in his soldier's death. To the feet of that shaft I shall send my children's children to reverence him who ennobled their name with his heroic blood. But, sir, speaking from the shadow of that memory, which I honor as I do nothing else on earth, I say that the cause in which he suffered and for which he gave his life was adjudged by higher and fuller wisdom than his or mine, and I am glad that the omniscient God held the balance of battle in His Almighty Hand, and that human slavery was swept forever from American soil - the American Union saved from the wreck of war.

This message, Mr. President, comes to you from consecrated ground. Every foot of the soil about the city in which I live is sacred as a battle-ground of the republic. Every hill that invests it is hallowed to you by the blood of your brothers who died for your victory, and doubly hallowed to us by the blood of those who died hopeless, but undaunted, in defeat - sacred soil to all of us, rich with memories that make us purer and stronger and better, silent but stanch witnesses in its red desolation of the matchless valor of American hearts and the deathless glory of American arms-speaking an eloquent witness, in its white peace and prosperity, to the indissoluble union of American States and the imperishable brotherhood of the American people. 
Now what answer has New England to this message? Will she permit the prejudice of war to remain in the hearts of the conquerors? Will she transmit this prejudice to the next generation, that in their hearts, which never felt the generous ardor of conflict, it may perpetuate itself ? Will she withhold, save in strained courtesy, the hand which, straight from his soldier's heart, Grant offered to Lee at Appomattox? Will she make the vision of a restored and happy people, which gathered above the couch of your dying captain, filling his heart with grace, touching his lips with praise and glorifying his path to the grave; will she make this vision, on which the last sigh of his expiring soul breathed a benediction, a cheat and a delusion? If she does, the South, never abject in asking for comradeship, must accept with dignity its refusal; but if she does not-if she accepts with frankness and sincerity this message of good will and friendship, then will the prophecy of Webster, delivered in this very Society forty years ago, amid tremendous applause, be verified in its fullest and final sense, when he said, "Standing hand to hand and clasping hands, we should remain united as we have for sixty years, citizens of the same country, members of the same government, united all, united now, and united forever. There have been difficulties, contentions, and controversies, but I tell you that in my judgment

\section{" "Those opposed eyes,}

Which, like the meteors of a troubled heaven, All of one nature, of one substance bred,

Did lately meet in th' intestine shock,

Shall now, in mutual, well-beseeming ranks March all one way.'" 


\section{APPENDIX C}

ONE HUNDRED ORATION SUBJECTS, ${ }^{1}$ WITH BRIEF HINTS FOR TREATMENT

I. The Saloon in Society.

Article in Atlantic Monthly, Vol. 59, p. 86.

2. The Good Old Times.

When a fair comparison is made, have we progressed so rapidly as is commonly asserted? While we have gained much, have we not also lost much? Is all change progress? Is it wholesome never to "have time"? Have health, morals, manners, faith, fidelity, nobility, increased in proportion to material advancement?

The other side of the question also presents strong arguments.

3. Young Fogies.

See dictionary. "Old men for counsel, young men for war." Certain conservative tendencies in the young are quite marked. Not all old men are

${ }^{1}$ It should be remembered that subjects are not necessarily titles. See pp. 62-64.

These hints are not intended to serve as outlines, but are designed to stimulate thought; for this reason many of the ideas take the form of questions. 
"slow," and not all young men are progressive. Youth is no guarantee of energy. Young minds feeding themselves on doubts and sneers are pitiable. In youth we look for buoyancy, hope, faith, cheer, "vim," and open-heartedness. What influences now at work make for "fogeyism" in the young? Are such influences wholesome? If not, what are the best counteractives?

4. Not to Thyself Alone.

Political economy teaches man's dependence upon man. The highest recognition and fulfillment of this large obligation is characteristic of the ideal life. Examine lives of great men for examples.

5. Free Speech.

Strictly speaking, there can be no free speech consistent with the welfare of society. Note the ways in which free speech can work harm. How can we remedy the evil without going to the opposite extreme? Our present "license" is one of the results of the French Revolution, says Bishop H. C. Potter.

6. The City a Menace to the Republic.

The Twentieth Century City, Strong. Democracy has failed in large cities because of the great influx of foreigners. Moral questions. Social questions. The saloon a large factor in city life. What part will the public school play in reform? Is the press too venal to help? Is the Church prepared to help? 
7. Blood Money.

In how far does money carry with it the taint of illgetting? Is there any obligation resting upon children to restore ill-gotten gains inherited from parents? If money is used to get other money dishonestly, can it bring blessing? Can a city, a state, a nation, afford to take blood money? Consider the case of Judas.

8. My Country Right or Wrong.

Is this a safe motto? How far may it be wisely followed? How trustworthy is individual opinion as against national policies? To what extent may a good citizen carry his protest against his nation's course? Does patriotism demand the surrender of conviction? Are majorities oftener right than wrong?

9. The True Aaron Burr.

In the light of recent books, the true character of the famous duelist is being studied more generally than ever. What grounds, if any, are there for a revision of public opinion on his case ?

io. The Influence of Art upon Morals.

Distinguish between prudery and modesty. Is contemporary art calculated to improve public morals? Is it true that "to the pure all things are pure"? Is the nude merely a question of custom?

i I. Crossing the Rubicon.

A lesson from Cæsar's careful deliberation and final decision. Rubicon days come to all of us. 
"There is a tide in the affairs of men," etc. The decision is often, unconsciously, a result of past life. Value of a decided character. How decisions reach from Gaul to Rome. "It might have been." Each side of the Rubicon has its duties - choice must be not only made, but also sustained.

I2. The Patriot Schoolmaster.

Nathan Hale. See biographies. Note how fidelity to small duties led up to his triumphant death. He could not have given so much to his country, had he lived a hundred lives, as he gave in his heroic words before his execution.

13. The Golden Mean.

The importance of a broad view of life and of its issues. The one-sidedness of the extremist. Truth walks on middle ground.

14. A Panacea for Poverty.

Many solutions proposed. Will there always be a class known as the poor? Article by Dr. Rainsford, "What can We do for the Poor ?" Forum, April, I891. Are preventive or remedial measures better? See Madison Peters's book, The Panacea for Poverty; and "Problem of Poverty," Century, December, I892.

I5. The Traitor-patriot.

The two sides of Benedict Arnold's career. Trace the influences which culminated in the sad turningpoint. How far did his repentance go to atone for his treason? 
i6. Does Education bless all Men?

Some men should not be educated, declares a wellknown public man. Under what circumstances could education prove a curse? Does this apply merely to partial education? Can all-round education ever be a curse?

I7. The University Idea.

Foreign compared with American universities. Wide variety in America. Sketch what you conceive to be the true idea. Support your position. Difficulties in America. Is American educational thought gradually agreeing upon an American university idea? Is any American university more nearly than others approaching the true ideal?

I8. The Quest for the Unknown.

How it has inspired inventors and discoverers. Examples. Much still remains unknown. Rewards awaiting the discoverer and inventor. A lesson of patience.

i9. Paternalism.

Consider the errors of the extreme socialist, who dreams of a time when the government will control all departments of labor and administration. The opposite of individualism.

20. The Aristocracy of Talent.

What is talent? Not confined to the aristocracy of blood. Why this fact is a matter for hopefulness. How fully does the world recognize this aris- 
tocracy? How does it rule? Illustrate how brain controls labor, and how the originator in any department is the world's ruler.

21. Circles.

See Emerson's Essay on "Circles."

22. "Gumption."

An oration in praise of common sense and its uncommon utility in all affairs of life. Show how What nothing can take its place.

23. An Uncrowned QueEn.

A eulogy of Miss Frances E. Willard.

24. Mental Indigestion.

Most men read too much, and do not digest what they read. We are losing taste for profound books. "Education is learning to read," says William Cowper Conant. If we cannot digest and assimilate what we read, why read at all? What is the remedy? See p. 65 et seq.

25. The "Honor System" in Examinations.

Review of the various college systems. Can all students be trusted? Explain the "honor system" (Lawrenceville, for example). Defects and merits.

26. The Educated Criminal.

What forces tend to criminality? How does education operate with respect to such forces? Can education be depended upon to counteract crime? How does it come to pass that educated men prove to be the most dangerous criminals when once they turn to crime? 
27. Good Men as Accomplices of the Bad.

How the apathetic, stay-away-from-the-polls citizen becomes the accomplice of the bad citizen by turning over to him the governmental power.

28. Charity, Wise and Otherwise.

Only that charity is wise which helps the recipient to help himself. The mischief of fostering dependence and pauperism.

29. The American Mechanic.

His career, his trials, his triumphs, his rewards, and his future. Has he had his due?

30. Old Stonewall.

A eulogy of the personal character and military genius of Stonewall Jackson.

3I. The Woman of the South.

Her noble spirit in devoting herself to the rehabilitation of her land after the horrors of war. Her influence which heartened the men of the South to take up the same duty. See p. 23I.

32. The Ethics of War.

What provocations can justify war? With what spirit should it be carried on? Compare late wars with those of former years. Has the spirit of humanity progressed? Consider the attitude of the victor toward the vanquished.

33. The Hour and the Man.

Great crises in the history of the world have generally found some man of towering ability to meet the need of the hour.. The reciprocal influence of great events and great men. 
34. Rub or Rust.

An oration of analogies. Labor or decay. Advance or retrograde. Conquer or be a slave.

35. The Tenth Legion.

Lessons from Cæsar's famous band.

36. A Womanly Queen-a Queenly Woman.

Queen Victoria. Special reference to her home life and training of her family. Her influence upon the, world's womanhood.

37. WOMAN AND WAR.

Her services at home and in the field. Her inspirational attitude. Examples from history: the ladies of Weinburg, Joan of Arc, Florence Nightingale, and many others.

38. The Three Duties of Man.

To himself, to fellow-man, to God. These duties can never really conflict, though at times they may seem to do so. In proportion as each is properly met, the others will also be performed. Illustrate. An all-round conception of duty.

39. The Right to Work.

See The New Right, by "Golden Rule" Jones. This is one of the natural rights of man. Selfsupport, and the support of those dependent upon him, involve labor. No system can be right which makes it increasingly difficult for an honest, efficient man to find employment. What forces seem to militate against this right? Are strikers justified in taking from others the right to work? 
40. The Tramp.

Tramping with Tramps, Flynt; "How Men become Tramps," Flynt, Century Magazine, Vol. 28, p. 4I. Is the tramp responsible for himself? If so, why? What part has society played in making men tramps? How can society prevent the making of more tramps? What can be done for the tramp? Whose business is it? Are all tramps of the same sort? The value of Mr. "Flynt's" work.

41. Cross and Crescent.

An outline of the rise of Christianity and the decline of Islam. What are the signs of the present times?

42. The Survival of the Fittest.

Illustrated in the mineral, vegetable, animal, and spiritual kingdoms.

43. Ignorance a Menace to the Republic.

Our great political controversies are decided by the ballot. The ignorant voter makes vicious legislation and incompetent office-holders possible. Since republican principles require an intelligent comprehension in order to their wide acceptance, can the illiterate voter wisely meet the duties and questions that confront him? The remedy.

44. Drifting.

Purposeless lives are drifting vessels. The start; the storm; the disaster; drifting; the end. What purposes are worthy to shape the courses of our lives? 
45. The Duality of Self.

Every man feels within himself, more or less fully, both "Dr. Jekyll and Mr. Hyde." Which is the true self? This is a matter of choice.

46. Destiny Versus Choice.

Our future is not controlled by our stars, but by ourselves. Consciousness of the power of choice. The ancient world bound by status. Illustrate how neither excellence nor shame are purely gifts of destiny, but depend largely upon our own desires and endeavors.

47. FEAR.

Analyze it. Various kinds, and various aspects. How it has hindered progress. How it has preserved much that is best. How may it be controlled so as to operate only for man's good?

48. Doubt, an Element of Intellectual Progress. Credulity versus doubt. Doubt not mere unbelief. Reasonable grounds for doubt. No discoveries without doubt as to accepted explanations of things. When doubt ceases to be a virtue. Doubt must be controlled by testimony.

49. The Pessimist.

Define. Analyze the mental states productive of pessimism. How is it related to unbiased truth? Does it paralyze or prosper the activities of man? Effect upon others. The final type of spirit into which pessimism deteriorates. Criticism to be valuable must be more than destructive - it must be constructive. 
50. MT. Vernon.

Suggestions from the grave of Washington - its message to Americans of to-day.

5I. The Passing of the Individual.

The age of organization, of combination, and of machinery is said to operate against the development of personal traits in men. Is this true?

52. The Stranger within our Gates.

Our duty to the foreign immigrant. Tis contributions to America's greatness, and the curses he has brought with him. The wisdom of a limited exclusion act. "Immigration and Degradation," Walker, Formm, August, r89r.

53. The Specialist.

What conditions have given rise to specialism? What foundation is necessary? What rewards await him? Does he benefit society? Are there any dangers to be avoided?

54. The Pleasures of the Poor.

The public interest in the condition of the poor. To what this interest may lead. Show how pleasures are an index to character. Do the pleasures of the poor elevate or demoralize them? How far are we responsible for these conditions?

55. "Remove not the Ancient Landmark."

America's carelessness as to historic and literary landmarks. Compare with Europe. Who shall take up this work? The good work already done in this direction; cite examples. 
56. REALism in Fiction.

Define realism. Should literary art deal with themes merely because they are true to nature? A mud puddle is true to nature. So is a crystal spring. Which should be held up to view? Is this a fair comparison?

57. Government by Injunction.

The tendency of modern times to permit the courts to set up or overthrow law. Is this right? What objections? Why valuable to society? Should it be modified or abolished?

58. The Mother of the Flag.

The story of Betsy Ross.

59. The Gift of the Puritan to America. See Introduction, in Painter's American Literature.

6o. The Sabbath a National Necessity.

Effect upon physical, mental, and moral well-being of our citizens. Compare the ten-day week tried during the French Revolution.

6i. The Future of the Negro.

"Thoughts on the Negro Problem," Bryce, North American Review, Vol. I53, p. 64; Up from Slavery, Washington; "Colored Race in the United States," Walker, Forum, July, I89r. Is the negro question nearing solution? Shall he continue to hold the ballot? Must the race question be settled by the white man alone? Will industrial education help solve the problem?

62. Literature as a Profession.

Besant, Forum, August, 1892. 
63. "Morituri Salutamus."

A message from the graduates to the undergraduates.

64. Vale, Alma Mater!

A farewell to the college.

65. Magna ex Parvis.

A study of the nature of growth - particularly with regard to the evolution of the great from the small. Illustrate from nature, and, apply to the greater considerations of life.

66. Loyalty to the Machine.

The old idea of politics was subordination of the individual to the will of the "machine." Show how reform is shattering this feudal notion and substituting a more exalted ideal of citizenship.

67. A Plea for the Capitalist.

The laborer has had his apologist; why not the capitalist? Can we estimate him justly without trying to understand his view-point, his difficulties, his problems, his weaknesses, his motives, and his environments?

68. Social Environment.

Show how large a factor in conduct, aims, and ideals is social environment. What would be the effect upon general manhood and womanhood if the social environment could be improved? Would that be sufficient to reform society? What part does man have in the formation of his own environment? 
69. Literature the Test of an Epoch.

The ideals of an age are reflected in the books its men and women love to read. We must distinguish between books read with serious intent and those read for mere diversion.

70. The Machine and the Man.

Two views may be taken. The pessimistic, which sees in the perfection of labor-saving devices the destruction of the value of man as an individual. The optimistic, which sees in the same fact the elevation of mind over matter, and the field for the exercise of man's individuality.

7I. The Blessings of Discontent.

No progress possible when men are supremely satisfied with their condition. Restlessness under unsatisfactory conditions has resulted in needed revolutions, given birth to liberty, inspired discoverers, nerved inventors, and, in general, furnished the motive for betterment in every department of life.

72. Commercialism.

The danger that our commercial prosperity may so pervade our national life as to make the dollar the standard by which all things are to be measured. What influences may be relied upon to oppose and check this tendency?

73. A Message from the Acorn.

A lesson of modesty, patience, and of immense possibilities wrapped up within small compass. 
74. The Gain of Loss.

The loss of some things is a great gain. Consider how that sacrifice is ever the foundation for gain. Illustrate from the affairs of life. Apply this truth to the higher interests of the mind and of the heart.

75. Man's Natural Right to Death.

Modern medical science seeks to prolong life even at the cost of the unspeakable misery of the patient. Is this right? Has not a man the right to die when nature so dictates? Is the prolongation of misery justifiable? What dangerous doctrines may be deduced from this theory?

76. The Gratitude of a Republic.

Instances in the history of our nation where a "republic is ungrateful." The opposite view also presents many examples.

77. A Citizen of the World.

A cultivated man owes allegiance first of all to his own flag, but his duty does not stop there - he should be a cosmopolitan. The interests of all men should fill his heart. This spirit has given birth to International Law, treaties, the protection of weak nations, the Red Cross, etc.

78. Flood Tide.

The "tide in the affairs of men, which, taken at the flood, leads on to fortune," is called opportunity. The day of flood tide often passes before we are aware. Illustrate. 
79. "Every Man has his Price."

Horace Walpole's cynical remark is not true now, nor was it true even of his own corrupt era. Of what sort are the men who cannot be bought? Examples.

80. The Spolls System.

See sermon preached by the Rev. Dr. Henry van Dyke, reported in the New York Tribune, February 25,1895 .

8I. I Believe.

How thorough must investigation be before one may truly say, "I believe"? Credulity versus belief. The lightness with which men say these words. Give examples how belief has influenced the lives of great men, and, through them, the world.

82. The Eternity of Law.

The dignity of law appears when we view its eternity. A universe without law is inconceivable. Even God was always a law unto Himself, and always will be, so that $\mathrm{He}$ cannot act inconsistently with Himself. This eternity of law is Truth. What are the conclusions from this doctrine?

83. Locks AND Keys.

There is a key for every lock. No difficulty so great, no truth so obscure, no problem so involved, but that there is a key to fit the lock. The search for the right key, the struggle to adjust it, the vigilance to retain it - these are some of the problems of success. 
84. Called to a Kingdom.

The career of the scholar, the business man, or the professional man. Outline the extent of the kingdom opening before him. He is called, but to possess it he must win it, as Israel won the Promised Land. What are the foes? What type of self-conquest is necessary to win it? What will he do with it?

85. Athens, Rome, Jerusalem.

Athens stands for culture, Rome for law, Jerusalem for religion. Compare these three centers of influence. Show how they must all be recognized in order to secure an ideal civilization.

86. Taxation without Representation.

The right of women to vote.

87. The Imperatives of Destiny.

The theory of the freedom of the will must be viewed in the light of God's rulership. God seems to have marked out certain men for great careers. Illustrate from history. The force of the divine "Thou shalt!" and "Thou shalt not!"

88. ТАвоO.

See dictionary. We should not fear to trespass on the taboos of superstition and of tradition in our search for truth. Examples: Galileo, Columbus, Miles Coverdale, et al.

89. The New Patriotism.

The result of the Spanish-American War. The united country. The self-sacrifice of countless citizens. The unifying of all classes. 
90. The Standards of the "Old Grads."

The achievements of the old graduates call upon the young people of to-day to set up these noble deeds as standards to be equaled and surpassed.

91. On the Firing Line.

The tests of life's realities after the years of college preparation. Bravery or cowardice - which?

92. On the Edge of the Future.

The future holds an invitation, a treacherous greeting, a sincere welcome, a closed door, a hostile front. How shall we approach it?

93. A Prince of the Fourth Estate.

A eulogy of Horace Greeley. Edmund Burke called the representatives of the "press" the "fourth estate."

94. Classical Education.

The present tendency is distinctly utilitarian. Cui bono? is the universal cry. Men specialize too soon-before laying the broad foundation of classical knowledge. The opposite ground may also be taken.

95. The Meaning of History.

History is example. Its lessons enable men of to-day to take up the problems of life with more confidence. What are some of the greatest lessons which history teaches us?

96. Blue Spectacles.

The tendency to look at everything through the discouraging "blue glasses" of pessimism. 
97. "Are we a Prosperous People?"

Article in Arena, January, I 893, by Flower. There are varieties of prosperity. What are the essentials of the true kind? How shall we apply these tests? Are men brave enough to discard the false standards and adopt the true?

98. "Social Science in Business Life."

Article in Chautauquan, September, I892, by John Habberton.

99. Outward Bound.

Commencement thoughts - a glance backward, and a forward look.

100. The Gospel of Helpfulness.

This is the heart of humanity and of religion. What are its source-spring, its methods, its end, and its rewards? 


\section{APPENDIX D}

\section{ONE HUNDRED ADDITIONAL SUBJECTS FOR}

ORATIONS

I. The Influence of Naval Battles upon History.

2. The Decline of the Drama.

3. Eulogy of Peter Cooper.

4. The Power of the Press.

5. Militarism Europe's Burden.

6. Invective against Napoleon.

7. The Great Lord Protector.

8. The Demagogue.

9. John Marshall.

Io. Alfred the Great.

I I. The University Settlement.

I2. St. Helena.

13. The Decline of Spain.

14. International Arbitration.

I5. Compulsory Education.

I6. Municipal Ownership.

17. The Problem of Poverty.

I8. The Relation of Wealth to Happiness.

19. Compulsory Physical Education.

20. The Heroes of Obscurity.

21. Public Opinion.

22. Reforms - False and True. 
23. The Tyranny of the Mob.

24. Loyalty to Conscience.

25. The Home and the State.

26. The Ballot a Responsibility.

27. The Strike as a National Issue.

28. Lafayette.

29. An Educational Test for the Suffrage.

30. The Future of Latin America.

3I. America a World Power.

32. Partisan Politics.

33. The Inventive Age.

34. Bismarck, the Iron Chancellor.

35. The Plutocrat.

36. Education the Safeguard of Liberty.

37. The Little Red Schoolhouse.

38. The Ministry of Adversity.

39. Deep Seas for Pearls.

40. Moses the Type of Jewish Jurisprudence.

4I. Booker T. Washington.

42. Censorship for the Press.

43. The Trust Dctopus.

44. The New South - Fifteen Years After.

45. Poverty and Crime.

46. "It is God's Way."

47. "A Message to Garcia."

48. Superstition.

49. Private Virtue and Civic Virtue.

50. A Defense of the Trust.

51. The Future of the Anglo-Saxon.

52. Wealth a Sacred Trust.

53. "Young Men of Yesterday." 
54. The Common People.

55. Memories.

56. American Humor.

57. Intercollegiate Fellowship.

58. Music and Culture.

59. Moral Courage the Power of a Soldier.

6o. Militarism a Menace to the Republic.

61. The Influence of the Theater upon Morals.

62. The Teacher a Public Benefactor.

63. The Law of Love.

64. Leadership.

65. The Riddle of Life.

66. The American Engineer.

67. The Devil.

68. Twentieth Century Knighthood.

69. Womanhood in Shakespeare.

70. Public Office a Public Trust.

7I. A Plea for the Kicker.

72. Dante as a Religious Teacher.

73. Hero Worship.

74. Idols of Clay.

75. Service the Object of Education.

76. New National Ideals.

77. "The Strenuous Life."

78. The Pennsylvania German.

79. The Quaker as a Colonist.

8o. I Will!

8I. The Politics of a Business Man.

82. Might and Right.

83. Science the Handmaid of Faith.

84. Commercial Expansion. 
85. Twentieth Century Christianity.

86. The Clergyman in Politics.

87. Modern Materialism.

88. Self-criticism.

89. Selfism versus Selfishness.

90. Egoism versus Altruism.

9I. The College Graduate in Business.

92. The Small College.

93. Self-culture.

94. The Death Penalty.

95. Conservatism the Friend of Progress.

96. Labor's Right to Organize.

97. "Luck is a Fool, Pluck is a Hero."

98. "Farthest North."

99. The Ethics of the Cartoon.

I00. The Jury System.

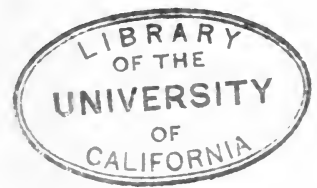




\section{INDEX}

Names of authors and speakers whose words are quoted, titles of parts, and headings of chapters are printed in small capitals; titles of books and of orations appear in italics.

A fortiori, 15.

A posteriori, I3.

A priori, 12.

Absurd illustration, 26.

Absurdity, Reducing to an, 22.

Accentuation, 126.

Accuracy in expression, 2.

Action, 45, I 30, I3I ; dignity of, 2 ;

related to will, I3I; Prepara-

TION FOR EXPRESSION BY (Chap-

ter XVII.), 130 ; rousing to, 33.

Actor's Art, Redway, 134.

Adams, John, 42.

Addresses, Extemporaneous, 34 .

Address to the American Troops,

Washington, 212.

Address to the intellect in persuasion, 29.

All's Well that Ends Well, Shakespeare, 76 .

Ambiguity, 26.

American Idea, The, Webster, 186.

Analogy, 15, 16.

Analysis, 9 ; value of, 169.

Ancient History, Rollin, 29.

Anniversary oration, 42.

Antecedents, Grammatical, 102, 103. Authority, 12.
Antony, Mark, 30, 32, 33.

Antonyms, 87.

Appeal, Emotional, 28, 29, 36; to

the will, 32.

Appendices, 169 .

Applause, 163.

Appreciations, 42.

Appreciations, Pater, 87.

Argument, Breaking down an, 12,

21 ; building up an, 12.

Argumentation, 6; compared with persuasion, 28; defined, 10; rules for, II-28.

Argumentation, Principles of, Baker,

$6,72,170$.

ARIstotle, 36, 40.

ARNold, MatThew, II3, I6I.

Articulation, 122, 124.

Artists, 51 .

Art of Extempore Speaking, The,

Bautain, 20, 1 I I, 1 I3.

Assimilating thought, I64.

Attention, 177.

Audience, 5, 46, 58, 59, 77, 149 ;

FACing THE (Chapter XX.), I 54 ;

Helps and HindRances in the

(Chapter XIX.), I49. 
Babcock, Maltbie D., 9I.

Bacon, Francis (Lord Verulam), 8 I.

Baker, George Pierce, 6, 72, I 70.

Baker, Ray Stannard, r8o.

Balanced sentences, IOI.

Barbarisms, 100.

Barrie, James Matthew, 88.

Bautain, M., 20, II I , II3.

Beatitudes, The, 17.

Beecher, Henry Ward, 4I, 54, I IO, I 5 I, 163.

BeEcher, Lyman, 44.

Before an Audience, Sheppard, 113 , I 16, 124, 136, 164 .

Begging the question, 27.

Belief, 14.

Biglow Papers, Lowell, 165.

Birch, Tom, 97.

Bismarck, Otto Edouard LeoPOLD VON, 34 .

Black, Jeremiah S., 78.

Bonaparte, Napoleon, 196.

Boswell, James, 5 I.

Breathing, I 18.

Brevity, гб́2.

Briefs for Debate, Brookings and

Ringwalt, 72.

Brookings, W. DU B., 72.

Brougham, Lord Henry Peter, 9I.

Brutus, Marcus Junius, 30.

Buffon, Georges Louis Leclerc

(Comte de), 93.

Burden Bearing, 184 .

Burke, Edmund, 40, 163.

BURNS, ROBERT, I4I.

Butler, Nicholas Murray, 55.

Butler, Samuel, 8 I.
BuXton, Sir Fowell, 168.

Byron, Lord (George Noel Gordon), 55, 58, 118.

Cefar, Caius Julius, 141.

Carlyle, Thomas, 2, i 10, 164, 68.

Carpenter, George R., 178.

Carriage, 131, 163.

Cause and effect, Tests of reasoning involving, 13.

Cause to effect, Reasoning from, 12.

Cavan, Earl of, 48.

Certainty, 16.

Cervantes, Miguel de, 23.

Chesterfield, Philip Dormer

STANHope (Earl of), I68.

Children of the Poor, The, Parker, I 89.

Choate, Rufus, 2 I.

Choice, 83 .

Christ, $15,17$.

Christian nation, The United States a, 182 .

Churchill, Winston Spencer, 162. Cicero, Marcus Tullius, 2, I4I.

Circle, The vicious, 27; reasoning in $\mathrm{a}, 27$.

Circumstantial evidence, 13.

Cities, A nation of, $\mathbf{1} 81$.

City, The Twentieth Century, Strong, 181 .

Classification, 9.

Clearness in writing, 2, 93, 102, 103, 162.

Climax, 82; in description, 7 .

Coherence, 103.

Collectives, Use of, 102.

College orations, 43 . 
Commemorative oration, Webster's, 42.

Composition, First rule of good, 97. Composition-Rhetoric, Scott and Denney, 175, 176.

Conciliation with the American Colonies, Burke, 40.

Conclusion of discourse, 160 .

Conclusion of syllogism, 16, I7, 18, 19, 20, 25, 26.

Condensation in description, 7 .

Confidence, before speaking, 154 .

Consonants, 127.

Conversation, 97, 117, 164; voice in, II 7.

Coriolanus, Shakespeare, I30.

COWPER, Wili.iam, 75.

Crisis, The, Churchill, 162.

Criticism of self, 122, 138, 141.

Crasus, 29.

Crown, Demosthenes on the, 173.

CTesiphon, I 72, 1 73, 174.

Cumulative evidence, 14 .

Curran, John Philpot, 201.

Cyrus, 29.

Damocles, The Sword of, Green, 51 . Dartmouth College Case, The, 37, 40, 79.

Davy, Sir Humphry, 126.

Debate, Briefs for, Brookings and Ringwalt, 72.

Declamations, 34, 35, 1 70, 186-239. De Corona, Demosthenes, 173.

Dedicatory oration, Lincoln's, 42, 198.

Deduction, 16.

Defence of Rowan, Curran, 201. Definition, 9, 10.
Deliberative oratory, 40.

Delivery (Part IV.), 145.

Delivery, 147, 148, 157 .

Demonstrative oratory, 32, 40, 43 .

Demosthenes, 49, 50, I 72, I 73, 174. DenhaM, 76.

Denney, Joseph Villiers, I 75, 176. De Oratore, Cicero, 2.

Depew, Chauncey Miller, 42.

De Quincey, Thomas, 44, 92.

Derivations, Study of word, $9 \mathbf{I}$.

Description, defined, 6; rules for, 7 .

Deteriorative Pozver of Conventional Art over Nations, Ruskin, 83.

Determination, 68.

Diction, roo.

Dictionary, Use of the, 86, 100.

Digest OF RHEToRical RUles (Chapter XIV.), 100.

Dignity of action, 2.

Dilemma, 23; false, 24.

Directions to the players, Hamlet's, I 59.

Discourse, divisions of the, 108; Preparation of the (Part II.), 49; The Forms of (Chapter II.), 6; The Grand Divisions of THE (Chapter XI.), 76; the ideal, 84; The Kinds of Public (Chapter III.), 34; The Theory of Spoken (Part I.), I.

Discovery of America, The Norse, 178.

Discussion of words, 90.

Discussion, The, $76,8 \mathbf{I}$.

Divisions of the discourse, 108.

Don Quixote, Cervantes. 23.

Doyle, A. Conan, 12.

Drama, The, 36 . 
Drill, Preparation By (Chapter|Essay on Criticism, Pope, 65, 100, XVIII.), 138 .

Drummond, Henry, 16.

Dryden, John, 162.

EARLE, John, 97.

Earnestness, in delivery, 159; in gesture, I 37, I 59.

Education, 55, I10.

Effect to cause, Reasoning from, 13.

Elegy in a Country Churchyard, Gray, 5 I.

Elementary sounds of English, I 24.

Elements of expression, I I 8, I 20.

Elements of Rhetoric, Carpenter, 178 . Elocution, McIlvaine, I 24.

Eloquence (Chapter V.), 44, I30, I49; Bismarck on, 34; born of emotion, 29; De Quincey on, 44; Emerson on, 31, 44; Lyman Beecher on, 44; Webster on, 44. Emerson, Ralph Waldo, 3I, 44, 54, 56, 142.

Emotional appeal, 28, 29, 36.

Emotion, Excess of, 157; in the orator, 29, 36; how aroused, 31, 133, 163; how suppressed, 32; the spring of action, 29.

Emphasis, 104, 121.

Energy, 168; conserving, I14.

English Composition, Wendell, 78, $8 \mathrm{r}$.

English Prose, Earle, 97.

English Style in Public Discourse, Phelps, 152.

Enthusiasm, 134 .

Enunciation, 122, 127.

Essay on Biography, Carlyle, 110. I62.

Eulogy, 42; of Lafayette, Everett, 43; of Lincoln, Newman, 217. Everett, Edward, 43, 82, 216. Evidence, Circumstantial, I3; cumulative, 14.

Excitement, how restrained, 4.

Exercises, Voice, I18-1 22; in pronunciation, 128.

Exposition, 6; defined, 9; rules for, 12.

Expression, 100; elements of, 118, I 20.

Extemporaneous addresses, 34, 35.

Extempore Speech, Pittenger, II3.

Facial expression, 132.

Facing the Audience (Chapter XX.), I 54.

Facts, Getting at, II.

Fallacies, danger of, 23; defined, 25.

False conclusion, 25.

False dilemma, 24.

Figures of speech, 98, 105.

FISKE, JoHn, 178.

Flaubert, Gustav, 87.

Fluency of expression, 2.

Force, of language, 2 ; in composition, 93, 104.

Foreign immigration, 176 .

Foreign words, 100.

Forensic oratory, 40 ; selections, 35.

Francis, Sir Philip, 14.

Freedom or Slavery, Henry, 192.

Fulton, Robert I., 135.

Garrick, David, 135 .

Generalization, 9. 
Genung, John Franklin, 6, 10, 13 , 24, 37, 73 .

Gesture, I33, 134, I59, 164.

Gettysburg Oration, Lincoln, 42, I98.

GilChrist, DR., 97.

Gladstone, William Ewart, 95, I 54.

Glories of the Dawn, Everett, 216.

Goethe, Johann Wolfgang von, 146.

Goodrich, Chauncey A., 37.

Gordy, J. P., 29.

Gospel, The Power of the, 184 .

Grace in expression, 2.

Grady, Henry WoOdfin, 78, 226.

Grammatical rules for sentences, 102.

Grand Divisions of THE DisCourse, The (Chapter XI.), 76.

Grattan, Henry, 156.

GRAY, Thomas, 3, 5 I.

Green, Anna Katherine, 5 I.

Guesses at Truth, Hare, 40.

Guildenstern, 30.

Guillotine, The, Hugo, 209.

HALL, RoBert, 62.

Hamlet, Shakespeare, 30, 31, 120, 129, $138,159,162$.

Handbook of English Composition, Hart, 80, 92.

hare, A. W. AND J. C., 40.

Harmony, 93, 105.

HaRRISON, BENJAMIN, 199.

Hart, James Morgan, 80, 92.

Head in oratory, The, 132.

Helps and Hindrances in the Audience (Chapter XIX.), 149. Henry, Patrick, 153, 192.
Henry $V$., Shakespeare, 44.

Henry VIII., Shakespeare, II 2.

Heroes and Hero Worship, Carlyle, 2, I64.

Higginson, Thomas Wentworth, 165.

Highways of Literature, Pryde, 6.

Hill, Benjamin H., 78.

Hints from Horace, Byron, 58.

History, Ancient, Rollin, 29.

History of England, Macaulay, 27.

Holmes, Oliver Wendell, 125.

Holmes, Sherlock, 12.

Holyoake, George Jacob, II, 94, $137,158$.

Homiletic Review, 123.

Horace, 58, 94.

Hudibras, Butler, 8I.

Hugo, Victor, 209.

Human voice, The, I 6.

Hume, David, 135 , 175.

Humor, 153.

Huxley, Thomas Henry, 80.

Hyde, William De Witt, 98.

Hygiene of the voice, II8.

Hypothesis, An, 12, 16.

Idioms, 98, 105.

Illustration, 8, 10, 16, 106 ; absurd, 26.

Immigration, Foreign, 176.

Imperfect enumeration, 24, 28.

Importance of Scientific Knowledge,

The, Everett, 82.

Individuality, 5, 95, 96.

Induction, 12, 15, 16, 18.

Inference as argument, 15; as evidence, 14; from general principles, $\mathbf{} 6$. 
Intellect, Address to the, in persuasion, 29.

Introduction, 76, 79 .

Intuition, 12.

Invective, 42.

Irving, Sir Henry, 159.

JefFerson, ThOMAS, I5, 42.

Jerrold, Douglas William, 153.

Jesus Christ, I 5, I 7 .

Johnson, Life of, Boswell, 51, 65.

Johnson, Samuel, 5 I, 65, 97.

Joint inductive-deductive reasoning, 2 I.

Jonson, Ben, 160.

Joy, Babcock, 9 I.

Julius Casar, Shakespeare, 33.

Junius, The Letters of, 14.

Kinds OF ORatory, The (Chapter IV.), 40.

Kinds of Public Discourse, The (Chapter III.), 34.

Kingsley, Charles, 93.

KLOPSTOCK, FRIEDRICH GOTTLIEB, I 6.

Lafayette, Eulogy of, 43.

Landor, Walter Savage, 87, 93.

Last Speech, Robespierre, 214 .

Lectures, 43.

Legal oratory, 40.

LEIFCHILD, DocTOR, 156.

Letters of Junius, The, 14.

Lincoln, ABRAHAM, 42, 150 , 198.

Liverpool Speech, Beecher, I5I.

Localisms, 100.

Locke, John, 55.

Logic, 4, 10, I I, 18, 20.
Logical elimination, 24.

LONGFELLOW, HENRY WADSWORTH, I18, 141 .

Long sentences, ror.

Loose sentences, ror.

Lot's escape, 184.

Lowell, James Russeli, 165.

Macaulay, Thomas Babington, 27, $46,156,163$.

McCosh, James, Io, 18, 23.

McIlvaine, J. H., 124.

Major premise, 16, I 7, 18, 19, 20, 25, 26, 27.

Manhood and Money, 183.

Manuscript, Use of the, $7 \mathbf{I}$.

Marshall, John, 39.

Massillon, Jean Baptiste, 55.

Materials, The (Chapter IX.), 65.

MATTHEWS, William, 21.

Maupassant, Guy de, 87 .

Measure for Measure, Shakespeare, 6.

Memorizing, Preparation for, II3.

Merchant of Venice, The, Shakespeare, 18.

Metropolitan Police, Phillips, 82.

Midsummer Night's Dream, $A$,

Shakespeare, 163.

Mill, John Stuart, 18.

Milton, John, 157, 164.

Minor premise, 16, 17, 18, 19, 20, $25,26,27$.

Mirabeau, Gabriel Honoré de

Riquetti (Count of), 155.

Mitchell, Wilmot Brookings,

127.

Mixed figures, 106.

Moderation, 34 . 
Modern American Oratory, Ringwalt, 42, 76 .

Modifiers, IO2.

Molière, Jean Baptiste Poquelin, 27.

MOORE, JOHN TroTwOOD, 164.

Napoleon to the Army of Italy, 196. Natural Law in the Spiritual World, Drummond, 16.

Naturalized words, roo.

Nature of Public Speech, The (Chapter I.), 3 .

Narration, 6; defined, 8; rules for, 8.

Nervousness, $115,154$.

New Americanism, The, Watterson, 207.

Newman, John Philip, 217.

New South, The, Grady, 78, 226.

Non sequitur, 25.

Norse discovery of America, 178.

Notes, Management of, 69; speaking without, 35 .

Object of discourse, The, 74 .

Observation, 12, 53, 54 .

Obsolete words, 100 .

Occasional oratory, 41, 42.

Orations, 34; defined, 36; how to study, 169; outlines, I71-185; subjects for, 240-262.

Oration over the Athenian Dead, Pericles, I7I.

Orator, 94; defined by Aristotle, 36; defined by Cicero, 2.

Oratorical models, 169, 186.

Oratorical Vocabulary, How to ACQUIRE AN (Chapter XII.), 85.
Oratory and Orators, Matthews, $2 \mathrm{I}$. Oratory, deliberative or political, 4; demonstrative or occasional, 32, 4I; forensic or legal, 40; sacred or pulpit, 4I; THE KINDS oF (Chapter IV.), 40.

ORIGINALITY (Chapter VI.), 5 I. Our New Prosperity, Baker, 180.

Outline, The working, 72, 164 .

Paradise Lost, Milton, 164.

PARKER, JOSEPH, 98.

Parker, Theodore, 189.

PARKhurst, Charles H., II4.

Particular logic, 20.

Pascal, Blaise, 72.

Pater, Walter, 48, 87, 93.

Pause, I2I.

Pericles, 151 I 17 I.

Periodic sentences, ror.

Peroration, The, 38, 76, 81, 160.

Personal element in oratory, The, 36 , 72, $111,165$.

Personality and style, 93, 94, 96 .

Personality, Influence of the will in, 4, 5.

Persuasion, 6; defined, 28; not all of oratory, 36; Rufus Choate's ability in, 21.

Petitio principii, 27.

Phelps, Austin, 152.

Phillips, Wendell, 78, 82, 95.

Physical condition of the orator, 114 . Physical earnestness, 159.

Physiological Science, Relation of, to Other Branches of Knowledge, Huxley, 80.

Pitch of voice, 119.

Pittenger, William, 113. 
Pitt, William, 46, I49, 204. Plato, 14 I.

Plea for Cuba, A, Thurston, 221. Plea for Patriotism, A, Harrison, 199.

Plutarch, 49, 50.

Political oratory, 40.

Pope, Alexander, 65, 97, 100, 162. Popular oratory, 43.

Possessive, Use of the, Io2.

Practical Elocution, Fulton and Trueblood, I35.

Practice, 138.

Precision in the use of words, 88, 93, IOI.

Prefixes, Force of, $9 \mathbf{r}$.

Premise, Major and minor, 16, I7, I8, 19, 20.

Preparation, 48, 49, 149, I64; BY

DRILL(Chapter XVIII.), I38; FOR

EXPREssion by ACtion (Chapter

XVII.), I30; FOR EXPRESSION BY

VoICE (Chapter XVI.), II6;

Mental (Chapter XV.), II2;

neglected, 34; OF THE Discourse (Part II.), 49; OF THE SPEAKER (Part III.), I09.

Preyer, Thierry William, 54.

Principles of Argumentation, Baker, 6.

Probability, I6.

Progress of Poesy, The, Gray, 3.

Pronunciation, 122.

Propriety in words, 93, 100.

Prose and conversation, 97.

Prosperity, National, 176, I 77, 180.

Prudence, Of, Denham, 76.

Pryde, David, 6.

Psychology, Gordy, 29.
Public Discourse, Style in (Chapter XIII.), 93.

Public Speaking and Debate, Holyoake, I I, 94, 137, 158.

Public Speech, Nature of, The (Chapter I.), 3.

Pulpit oratory, 4I, 43 .

Pun, 26.

Purity in words, 93, 100.

Pytheas, 49.

Quality of voice, $\mathbf{1} 18$.

Railroads a universal benefit, 176 .

Reading aloud, 98.

Reasoning, The science and art of, 4.

Rebuttal, 22.

Recitations, 35 .

Reductio ad absurdum, 22.

REDWAY, 134.

Reeve, James KNAPP, 52, 53.

Refutation, 2 I.

Rehearsal, 138.

Relation of Physiological Science to Other Branches of Knowledge, The, Huxley, 80.

Repetition, 98.

Reply to Hayne, Webster, 77.

Reserve force, 95 .

Rest before speaking, I I4.

Resurrection of Christ, The, 23.

Revision, 75 .

Rhetoric, 4.

Ridicule, 26.

Right to Trial by fury, The, Black, 78.

Ringwalt, RaLPH CURTIS, 42, 72, 76. 
ROBESPIERRE, MAXIMILIAN MARIE ISIDORE DE, 214.

Rollin, Charles, 29.

Romeo and Fuliet, Shakespeare, I63. Rules, Digest of RHetorical

(Chapter XIV.), 100.

Rules, Function of, 75, 97, 143.

Ruskin, John, 54, 79, 83 .

Sacred oratory, 4I.

Sancho Panza, 24.

St. Luke, 15, 24.

St. Matthew, I 7.

School and College Speaker, Mitchell, $127,128$.

SCOTT, Fred NewTon, I 75, 176.

Self-criticism, 122, 138, 141, 162.

Self-evident truths, 18.

Self-government, 15.

Self-instruction, $1 \mathbf{r} 6$.

Self-mastery, 5, 157 .

Sentences, kinds of, ror ; variety in, 101.

Sentimental Tommy, Barrie, 87.

Shakespeare, William, $6,18,30$, 31, 32, 33, 44, 7 I, 76, I 1 2, 120, 1 29, 130, 138, 1 59, 162, 163.

SHEPPARD, NATHAN, I13, I16, 124, 132, 136, 152, 164 .

Shiel, 158.

Sidney, Sir Philip, 55.

Simplicity, 162.

Slang, 100.

SMITH, SydNEY, 157 .

Sorites, 19.

Sowing and Reaping, Beecher, 4I.

Speaker, Qualities of a, 2.

Speech, a thought-instrument, 3 ;

extemporaneous, 34 ; impromptu, $\mid$ Thinking, Consecutive, 55.
34; The Nature of Public (Chapter I.), 3; relation of, to emotion, 4; relation of, to will, 4 ; public, what is successful, 5 . Splendor of language, 2.

Stage-fright, $11_{5},{ }_{54}$.

Statement, The, 76, 79 .

Strong, Josiah, $18 \mathrm{I}$.

Style, IO2; in Public Discourse

(Chapter XIII.), 93.

Subject, The (Chapter VII.), 58;

choice of, $65,66,67$; relation of materials to, 65 .

Sublimity, 32.

Subjunctive, Use of the, ro2.

Substitution of terms, 26.

Success, how determined, 168.

Suffixes, Force of, 91 .

Suffrage, 60.

Summary, 98; in description, 7 .

Summer Hymnal, Moore, I64.

Sweetness and Light, Arnold, II3.

Sword of Damocles, The, Green, $5 \mathbf{I}$. Syllogism, The, 16; in enlargement,

I8; in enthymeme, 17,18 ; summary of regulating principles governing the, 20.

Synonyms, 26, 87, I01, 105.

Tact, 146, 153.

Tammany Hall, 78.

Temperance, Everett, 82.

Terence, Publius, 34.

Testimony, 12.

Thackeray, Life of, Trollope, 143.

Thackeray, William Makepeace, 142. Theory of Spoken Discourse, The

(Part I.), I. 
Thoreau, Henry David, 54 .

Thought, awakened, 2; colored by emotion, 4; distinguished from emotion, 4; speech an instrument of, 3 .

Thracians, 20.

Thucydides, I 7 I.

Thurston, John Mellen, 221.

Time, 120.

Title, The (Chapter VIII.), 62.

To a Louse, Burns, 141.

Toussaint L'Ouverture, Phillips, 78 . Translating, The value of, $9 \mathrm{I}$.

Trollope, Anthony, 143.

Trueblood, Thomas C., I 35 .

Turner and his Works, Ruskin, 79.

Two Gentlemen of Verona, Shakespeare, $7 \mathbf{I}$.

Tytler, Alexander Fraser (Lord Woodhouselee), 50.

Unity in discourse, 84, 93, 103. Unjust Steward, The, 24 .

Variety of expression, 106.

Vawder's Understudy, Reeve, 52.

Vicious circle, The, 27.

Vitality, 93, 105.

Vocabulary, defined, 85; How to ACQUire an Oratorical (Chapter XII.), 85,86 .
Voice, The human, I16; preparation of, 116.

Voltaire, Francis Marie Arouet de, I33.

War with America, The, Pitt, 204. Washington, George, 212; His

Contribution to Nationality, 175. Watterson, Henry, 207.

Webster, DANIEL, 37, 40, 42, 44, 77, 79, 95, 185.

Wellesley, Arthur (Duke of Wellington), $15^{8}$.

WeNdell, Barrett, 76, 81.

WhATELy, RichaRd, 10.

WhiteField, George, 135 .

Will, in public speech, 4, 117; in delivery, 155; in rehearsal, 140; in voice management, 117 ; necessary to the mastery of an audience, 5; appeal to in oratory, 32. Wit, I 53 .

Words, The study of derivation of 9I; from the Anglo-Saxon, 91; knowledge of, 85 ; obsolete, I00; precise use of, 88; too new, roo.

Working Principles of Rhetoric, Genung, 6, 10, 13, 24, 37, 73. Writing, The (Chapter X.), 7 I. Writing, The first, 74.

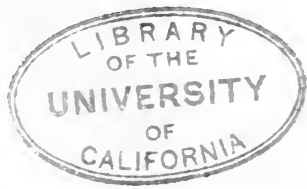




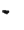




$$
\text { . }
$$




$1=5$ 


\section{UNIVERSITY OF CALIFORNIA LIBRARY BERKELEY}

Return to desk from which borrowed.

This book is DUE on the last date stamped below.

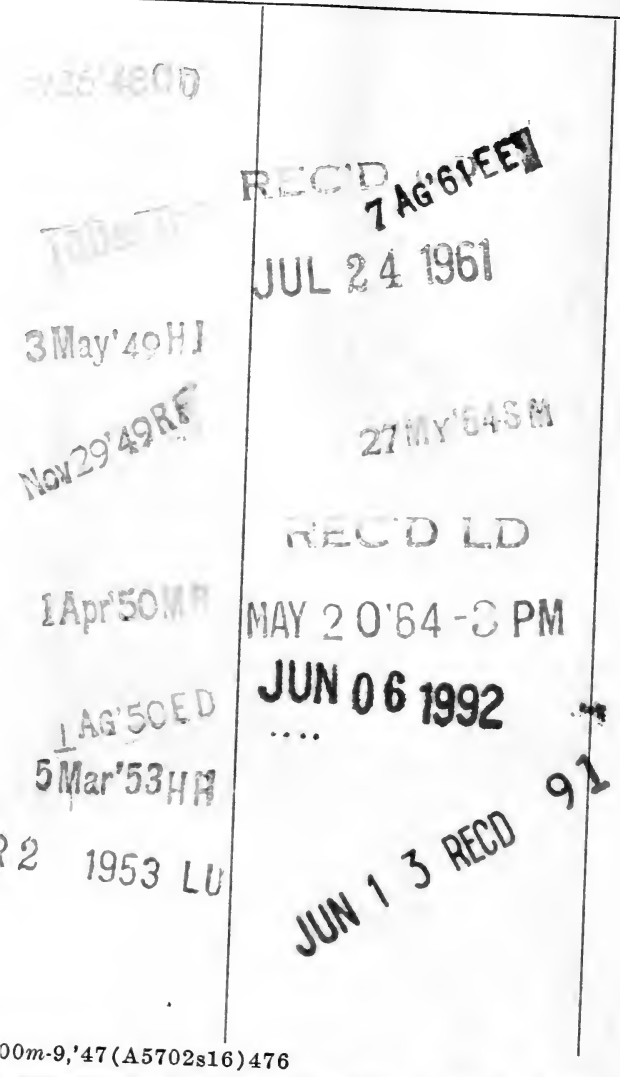


